\title{
Baseline Mapping Study of the Steed Pond Aquifer and Vadose Zone Beneath A/M Area, Savannah River Site, Aiken, South Carolina
}

by

D. G. Jackson Jr.

Westinghouse Savannah River Company

Savannah.River Site

Aiken, South Carolina 29808

W. Parker

A. D. Smits

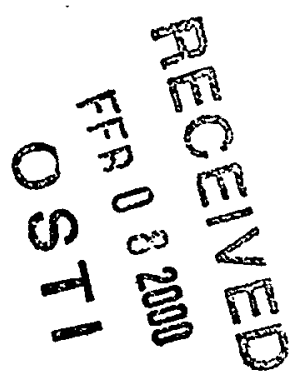

M. K. Harris

K. L. Hawkins

This paper was prepared in connection with work done under the above contract number with the U.S.

Department of Energy. By acceptance of this paper, the publisher and/or recipient acknowledges the U.S.

Government's right to retain a nonexclusive, royalty-free license in and to any copyright covering this paper, along with the right to reproduce and to authorize others to reproduce all or part of the copyrighted paper. 
Baseline Mapping Study of the Steed Pond Aquifer and Vadose Zone Beneath A'/M Area, Savannah River Site, Aiken, South Carolina (U)

Wayne H. Parker, Andrew D. Smits, Mary.K. Harris, Dennis G. Jackson Jr., and Kelley L. Hawkins

August 1999

Prepared by:

Westinghouse Savannah River Company Savannah River Site Aiken; SC.29808

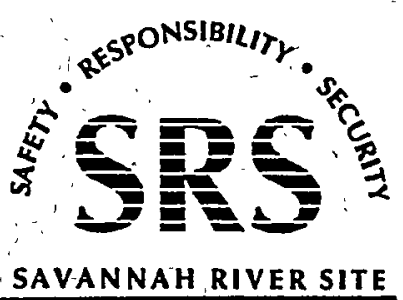

Prepared for the U.S. Department of Energy Under Contract Number DE-AC09-96SR18500 


\section{DISCLAIMER}

This report was prepared as an account of work sponsored by an agency of the United States Government. Neither the United States Government nor any agency thereof, nor any of their employees, makes any warranty, express or implied, or assumes any legal liability or responsibility for the accuracy, completeness, or usefulness of any information, apparatus, product or process disclosed, or represents that its use would not infringe privately owned rights. Reference herein to any specific commercial product, process or service by trade name, trademark, manufacturer, or otherwise does not necessarily constitute or imply its endorsement, recommendation, or favoring by the United States Government or any agency thereof. The views and opinions of authors expressed herein do not necessarily state or reflect those of the United States Government or any agency thereof.

This report has been reproduced directly from the best available copy.

Available for sale to the public, in paper, from: U.S. Department of Commerce, National Technical Information Service, 5285 Port Royal Road, Springfield, VA 22161, phone: (800) 553-6847

fax: (703) 605-6900

email: orders@ntis.fedworld.gov

online ordering: http://www.ntis.gov/ordering.htm

Available electronically at http://www.doe.gov/bridge

Available for a processing fee to U.S. Department of Energy and its contractors, in paper, from: U.S. Department of Energy, Office of Scientific and Technical Information, P.O. Box 62, Oak Ridge, TN 37831-0062, phone: (865) 576-8401

fax: (865) 576-5728

email: reports@adonis.osti.gov 
Baseline Mapping Study of the Steed Pond Aquifer and Vadose Zone Beneath A/M Area, Savannah River Site, Aiken, South Carolina (U)

Wayne H. Parker, Andrew D. Smits, Mary K. Harris, Dennis G. Jackson Jr., and Kelley L. Hawkins

August 1999

Prepared by:

Westinghouse Savannah River Company

Savannah River Site

Aiken, SC 29808

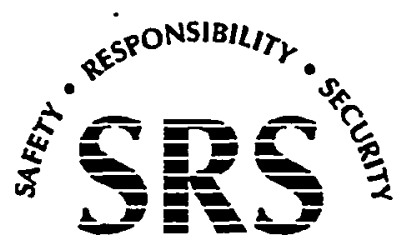

SAVANNAH RIVER SITE

Prepared for the U.S. Department of Energy Under

Contract Number DE-AC09-96SR18500 
ii

WSRC-TR-99-00295

Baseline Mapping Study of the Steed Pond Aquifer and the Vadose Zone Beneath A/M Area, Savannah River Site, Aiken, South Carolina (U)

Authentication and Approvals:

aye H. Taper

29/Ang/99

Wayne H. Parker, SAIC

Date

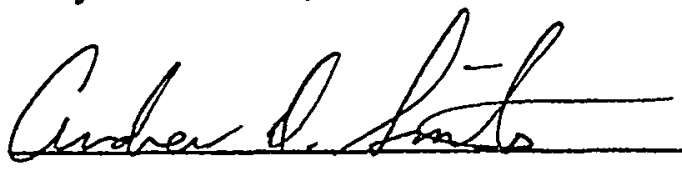

Andrew D. Sits, SAIC

$8 / 27 / 99$

Daman $\Delta$ hathor

8127190

Dennis G. Jackson Jr., WS kC - SRTC

Date

Heller A. Adaptions

Kelley L. Hawkins, SAIC
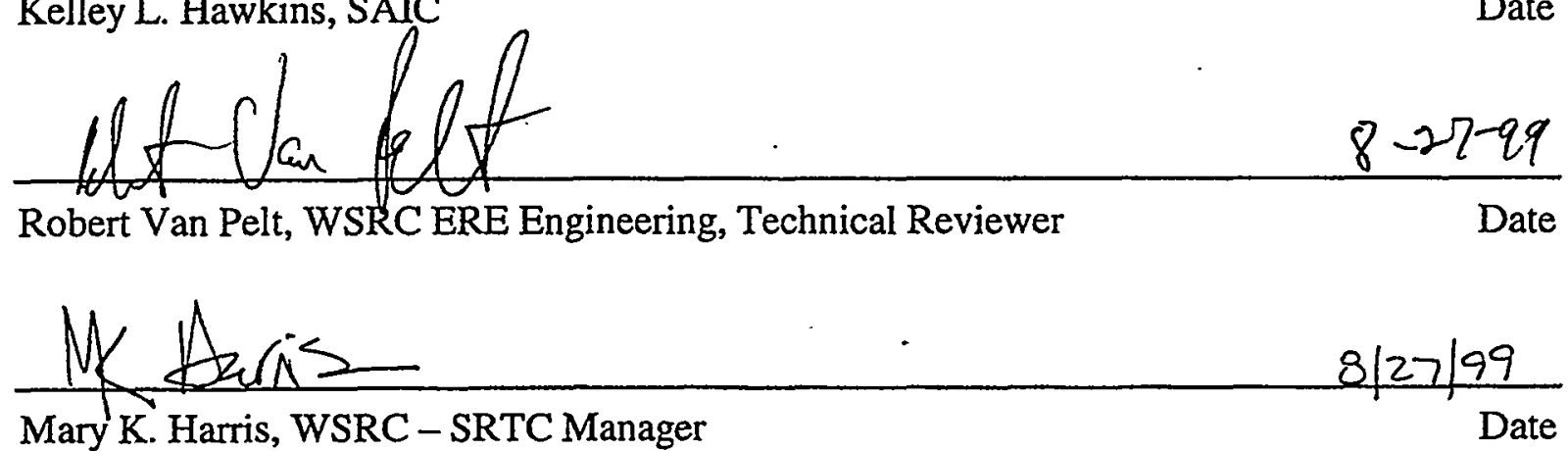

Mary K. Harris, WSRC - SRTC Manager

Date 


\section{EXECUTIVE SUMMARY}

This report presents the second phase of a baseline mapping project conducted for the Environmental Restoration Department (ERD) at Savannah River Site. The first phase investigated the Steed Pond Aquifer and Crouch Branch Confining Unit beneath A/M Area. The purpose of this second phase is to map the structure and distribution of mud (clay and silt-sized sediment) within the vadose zone beneath $\mathrm{A} / \mathrm{M}$ Area. Knowledge of the distribution of mud is essential to fully characterize the extent and behavior of dense non-aqueous phase liquid (DNAPL) and to determine the geometry of the contaminant plumes emanating from them. Detailed mapping of these layers can aid in locating areas where contamination is most likely to have migrated through the vadose zone into the saturated sediments. In addition, this information can be used to refine the current vadose/groundwater remediation systems or assist in designing new remedial systems.

Contour maps of unit tops, isopach, geometric mean of mud, and standard deviation of mud percentage were generated using EarthVision ${ }^{\circledast}$. This report models, in descending order, the informal "325-foot clay", "300-foot clay", "270-foot clay", and "230-foot clay" intervals, and the "green clay" confining zone of the Steed Pond Aquifer. The model is based on sedimentological and geophysical data from 83 selected cores in the study area. The results presented in this report will assist future characterization and remediation activities in the vadose zone and upper aquifer zones in $\mathrm{A} / \mathrm{M}$ Area. 
This page intentionally left blank 


\section{TABLE OF CONTENTS}

EXECUTIVE SUMMARY iii

LIST OF FIGURES ................................................................................................... vii

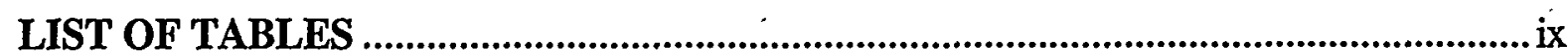

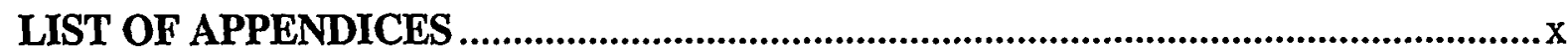

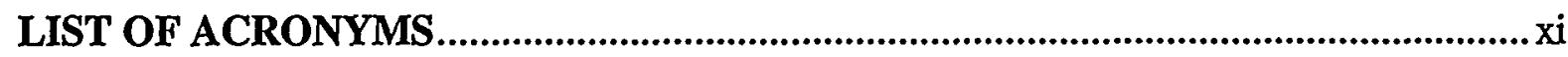

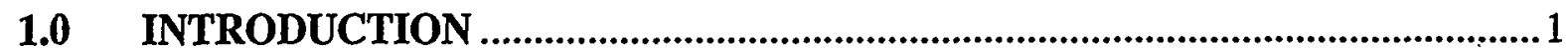

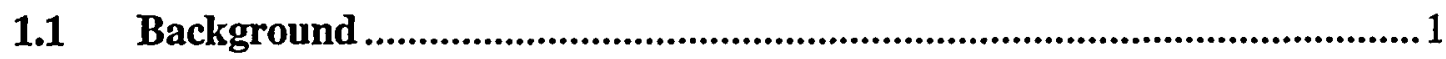

$1.2 \quad$ Objective and Approach .................................................................................

1.3 Description of the Study Area .......................................................................

1.3.1 Lithostratigraphy ...................................................................................

1.3.2 Hydrostratigraphy .............................................................................

1.3.2.1 Crouch Branch Confining Unit ....................................................4

1.3.2.2 Steed Pond Aquifer Zone ............................................................5

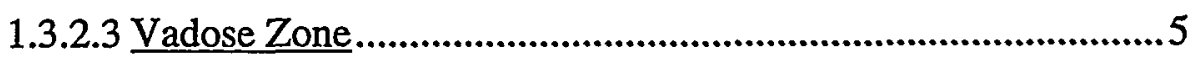

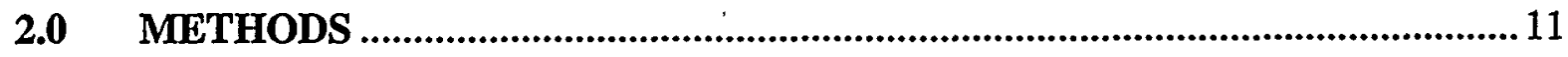

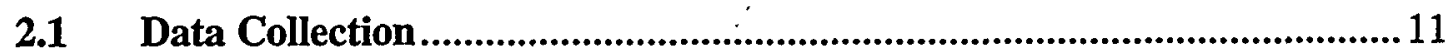

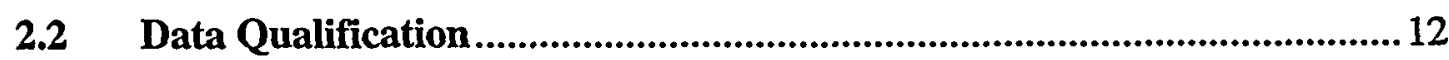

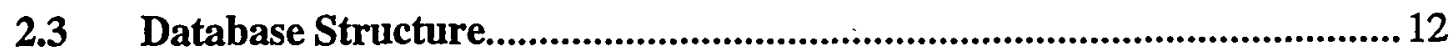

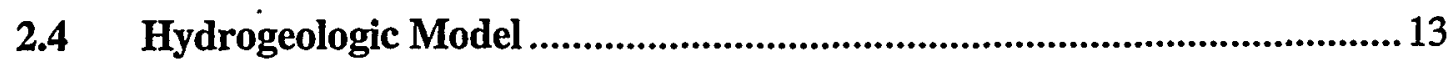

2.4.I Hydrostratigraphic Methods ........................................................... 13

2.4.2 Two-Dimensional Grid Calculation ................................................. 15 


\section{TABLE OF CONTENTS (Continued)}

2.4.3 Three-Dimensional Grid Calculation ............................................. 15

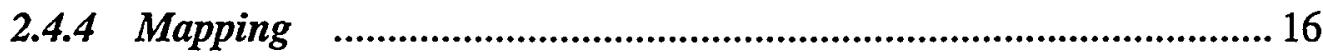

2.4.4.1 $\quad$ Altitude Contour Maps........................................................ 16

2.4.4.2 Isopach Maps............................................................... 16

2.4.4.3 Lithofacies Maps............................................................ 16

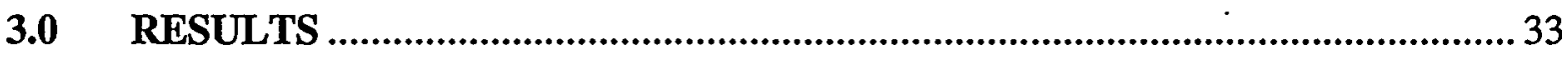

3.1 Unit Geometry and Facies Analysis …………............................................ 33

3.1.1 “Green Clay" Confining Zone ............................................................ 33

3.1.2 “M Area" Aquifer Zone/Vadose Zone ............................................... 34

3.1.2.1 "230-Foot Clay"'................................................................... 34

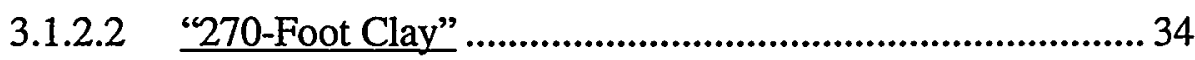

3.1.2.3 "300-Foot Clay" ....................................................................... 35

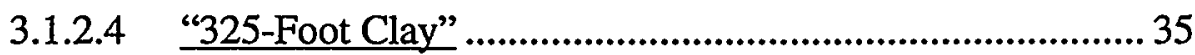

3.2 Comparison with Observed Extent of Groundwater Contamination ...... 35

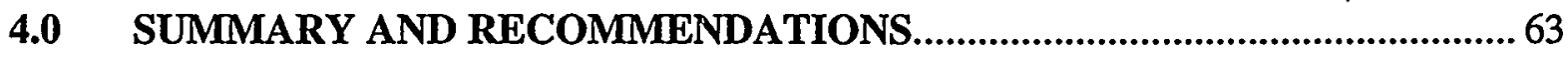

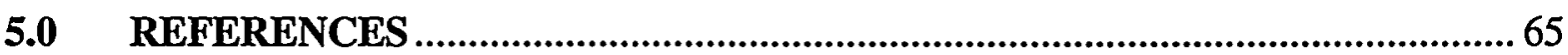




\section{LIST OF FIGURES}

1-1. Location of the Savannah River Site and the A/M Area..........................................

1-2. Topography of the A/M Area and Study Area Boundary ........................................

1-3. Comparison of Lithostratigraphic and Hydrostratigraphic Units beneath A/M Area at SRS.

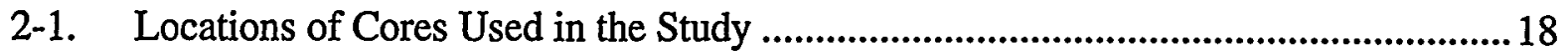

2-2. Composite Lithologic Log for SRS Core MBC-10SB .........................................19

3-1. EarthVision ${ }^{\circledR}$ Structure Builder Model of the Study Area...........................................38

3-2. Chair-Cut through EarthVision ${ }^{\circledR}$ Model................................................................39

3-3. Three-Dimensional Visualization of Mud Fraction within Model Domain ...................40

3-4. Altitude Contour Map of the Top of the "Lost Lake" Aquifer/Base of the "Green Clay" Confining Unit..

3-5. Altitude Contour Map of the Top of the "Green Clay " Confining Zone Base of the "M-Area" Aquifer Zone.

3-6. Isopach Map of "Green Clay" Confining Zone ........................................................43

3-7. Geometric Mean of Mud Percentage within the "Green Clay" Confining

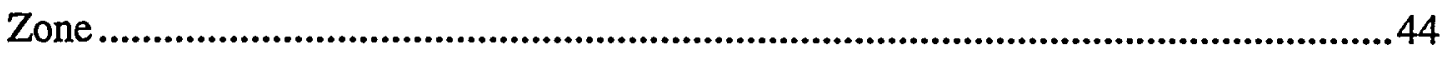

3-8. Standard Deviation of Mud Percentage within the "Green Clay" Confining Zone 45

3-9. Altitude Contour Map of the Top of the "230-Foot Clay"/Base of the "270-Foot Clay" .46

3-10. Isopach Map of the "230-Foot Clay". .47

3-11. Geometric Mean of Mud Percentage within the "230-Foot Clay" 48

3-12. Standard Deviation of Mud Percentage within the "230-Foot Clay" 49

3-13. Altitude Contour Map of the Top of the "270-Foot Clay"/Base of the . 


\section{LIST OF FIGURES (Continued)}

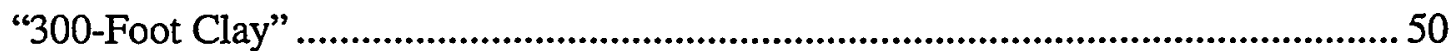

3-14. Isopach Map of the Top of the "270-Foot Clay" ............................................... 51

3-15. Geometric Mean of Mud Percentage within the "270-Foot Clay" ...........................52

3-16. Standard Deviation of Mud Percentage within the "270-Foot Clay" ......................... 53

3-17. Altitude Contour Map of the Top of the "300-Foot Clay"/Base of the

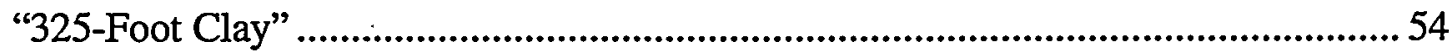

3-18. Isopach Map of the " $300-F o o t$ Clay" ................................................................... 55

3-19. Geometric Mean of Mud Percentage within the "300-Foot Clay" ........................... 56

3-20. Standard Deviation of Mud Percentage within the "300-Foot Clay" ....................... 57

3-21. Altitude Contour Map of the Top of the "325-Foot Clay"/Base of the Undifferentiated Sediments ............................................................................... 58

3-22. Isopach Map of the "325-Foot Clay" ........................................................... 59

3-23. Geometric Mean of Mud Percentage within the "325-Foot Clay" ........................... 60

3-24. Standard Deviation of Mud Percentage within the "325-Foot Clay" ...................... 61 


\section{LIST OF TABLES}

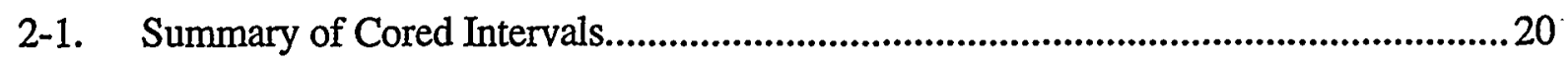

2-2. Coordinates of Core Locations................................................................. 24

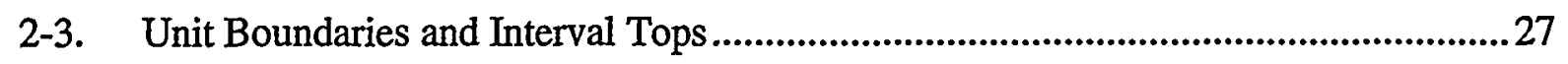

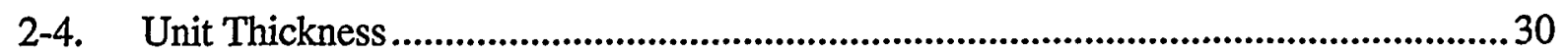




\section{APPENDICES}

A Core Descriptions

B SRS Core Logging Format 


\section{LIST OF ACRONYMS}

\begin{tabular}{|c|c|}
\hline bgl & below ground level \\
\hline bls & below land surface \\
\hline $\mathrm{CBA}$ & Crouch Branch aquifer \\
\hline CBCU & Crouch Branch confining unit \\
\hline DEM & digital elevation model \\
\hline DOE & United States Department of Energy \\
\hline DNAPL & dense, non-aqueous phase liquid \\
\hline ERD & Environmental Restoration Department \\
\hline ESSOP & Environmental Sciences Section Operating Procedure \\
\hline $\mathrm{ft}$ & foot/feet \\
\hline GCCZ & "green clay" confining zone (of the Steed Pond aquifer) \\
\hline GSA & General Separations Area \\
\hline $\mathrm{ID}$ & identification \\
\hline LLAZ & "Lost Lake" aquifer zone (of the Steed Pond aquifer) \\
\hline $\mathrm{mm}$ & millimeter(s) \\
\hline MAAZ & "M Area" aquifer zone (of the Steed Pond aquifer) \\
\hline $\mathrm{msl}$ & mean sea level \\
\hline PCE & perchloroethene (tetrachloroethylene) \\
\hline QA & Quality Assurance \\
\hline QC & Quality Control. \\
\hline RCRA & Resource Conservation and Recovery Act \\
\hline
\end{tabular}




\section{ACRONYMS (Continued)}

SPA Steed Pond aquifer

SRS Savannah River Site

SRTC Savannah River Technology Center

TCA 1,1,1-trichloroethane

TCE trichloroethylene

USGS United States Geological Survey

VOC volatile organic compound

WSRC Westinghouse Savannah River Company 


\subsection{INTRODUCTION}

\subsection{Background}

The Savannah River Site (SRS) is a U.S. Department of Energy (DOE) facility that was set aside in 1950 as a controlled area for production of nuclear materials for national defense. The DOE and its contractors are responsible for the operation of the SRS. Westinghouse Savannah River Company (WSRC) currently manages and operates the site.

This report focuses on the A/M Area, which is at the north boundary of the SRS (Figure 1-1). The $\mathrm{A} / \mathrm{M}$ Area includes SRS administrative support facilities (A Area), research and laboratory facilities, and facilities once used for fabrication of reactor fuel and target assemblies ( $M$ Area). Operations within the $\mathrm{A} / \mathrm{M}$ Area resulted in the release of chlorinated solvents containing volatile organic compounds (VOCs) to the subsurface (Marine and Bledsoe, 1984). Released solvents include trichlorethylene (TCE), tetrachloroethylene (PCE) and 1,1,1-trichloroethane (TCA) which have contaminated the soil and groundwater within the area. Between 1952 and 1982, an estimated 2 million pounds of solvents were discharged into the M-Area Settling Basin and 1.5 million pounds were discharged through an openended process sewer line into an unnamed tributary of Tims Branch. Since the detection of VOCs in the soil and groundwater, the SRS has aggressively pursued a rigorous program of soil and groundwater remediation. The SRS remediation program includes a series of soil-vapor extraction units for removal of contaminants from the vadose zone, an extensive network of recovery and recirculation wells for extraction and treatment of contaminated groundwater, and several deployments of innovative remediation technologies such as Fenton's reagent and co-metabolic bioremediation. This program provides source removal and control and hydraulic control to minimize plume expansion; future actions directly targeting dense non-aqueous phase liquids (DNAPL) and long term solutions for dilute plume areas are provided for in the Resource Conservation and Recovery Act (RCRA) groundwater corrective action permit. SRS supports research and demonstration program for innovative characterization and remediation techniques to maximize the efficiency and effectiveness of the SRS remediation strategy and to develop methods for the future permit activities. In particular, the SRS remediation strategy includes on-going characterization of subsurface features and conditions that may have a significant influence on groundwater flow and contaminant transport. 


\subsection{Objective and Approach}

This report presents results of the second phase of a baseline mapping project conducted by the Savannah River Technology Center (SRTC) for the Environmental Restoration Department (ERD) at SRS. This is a continuation of the Baseline Mapping Study of the Steed Pond Aquifer and Crouch Branch Confining Unit Beneath A/M Area, Savannah River Site, Aiken, South Carolina (U), (WSRC, 1998). The current report further delineates confining intervals within the vadose zone and maps the geometry and distribution of mud (clay and silt-sized sediment) within these units to the top of the "Lost Lake" aquifer zone beneath the A/M Area.

Recent characterization efforts emphasize locating DNAPL in the subsurface beneath A/M Area (Looney and others, 1992). Upon release at the surface, DNAPL migrates down through the vadose zone into the saturated zone. The relatively high density of the DNAPL causes it to move in an overall vertical direction, following a "path of least resistance" through zones of highly permeable gravel and coarse-grained sand. The DNAPLs tend to slow and spread laterally upon encountering strata composed of less-permeable silty sand and clay (Jackson and others, 1996). Potential migration paths and distribution of DNAPL are therefore related to the distribution and configuration of less-permeable, fine-grained sediment.

Once emplaced within the saturated zone, DNAPLs serve as a source for the release of dissolved VOCs to the groundwater. The groundwater carries dissolved VOCs as plumes, which emanate from the DNAPL source and extend in a direction parallel to the local hydraulic gradient. Movement of VOC-contaminated groundwater is largely controlled by the geometry and distribution of more permeable strata. The transport and fate of dissolved VOCs depends upon the extent of the DNAPL source, and the distribution of coarse-grained sediment within the aquifer.

The distribution of fine-grained sediment layers and variations in the quantity of clay and silt within the sediment is extremely important in order to fully characterize the extent of DNAPL layers beneath the $\mathrm{A} / \mathrm{M}$ Area and determine the geometry of the contaminant plumes emanating from them. Indirect assessment techniques have been applied to historical groundwater concentrations in the A/M Area and indicate that the distribution of DNAPL beneath A/M Area may be laterally extensive (Jackson and others, 1996). The delineation of layers of less-permeable sediment is therefore critical to aid remediation efforts. Detailed mapping of these geologic features can aid in locating areas where contamination is most 
likely to have migrated into the saturated zone. These data are valuable aids for accurate modeling of groundwater flow and contaminant transport. In addition, this information can be used to refine the current remediation systems or assist in designing new ones.

\subsection{Description of the Study Area}

The SRS comprises approximately 300 square miles within Aiken, Barnwell, and Allendale counties in southwestern South Carolina. The center of the SRS is 22.5 miles southeast of Augusta, Georgia, approximately 100 miles from the Atlantic Coast within the Upper Atlantic Coastal Plain Physiographic Province (Figure 1-1). The Savannah River forms the southwest boundary of the SRS. The SRS lies on the Aiken Plateau of the Atlantic Coastal Plain at an average elevation of 300 feet above mean sea level ( $\mathrm{ft} \mathrm{msl}$ ). The Aiken Plateau is well drained, although many poorly drained sinks and depressions exist, especially in upland areas. Overall, the Aiken Plateau displays highly dissected topography, characterized by broad interfluvial areas separated by narrow, steep-sided valleys. Local relief can attain 280 feet (Siple, 1967).

The A/M Area comprises approximately eight square miles near the northern boundary of the SRS (Figure 1-2).

\subsubsection{Lithostratigraphy}

The surficial geology of the SRS includes sediment of the Atlantic Coastal Plain. The Atlantic Coastal Plain consists of southeast-dipping, unconsolidated and semi-consolidated strata that extend from the Piedmont Province at the Fall Line to the edge of the continental shelf. Strata range from Late Cretaceous to Miocene in age and rest unconformably on crystalline and sedimentary basement rock (Figure 1-3). The sediment comprises interbedded sand, muddy sand, and mud (clay and silt), with a subordinate amount of calcareous sediment. The sedimentology of these strata indicates deposition in deltaic and near-shore environments that experienced considerable fluvial influence (Fallaw and Price, 1995).

The A/M Area lies within the up-dip area of the Coastal Plain deposits, approximately 20 miles from the Fall Line (Figure 1-1). Beneath A/M Area, the contact between Cretaceousaged strata and crystalline basement rock is found at a depth of 500 to 700 feet below the land surface (ft bls).

Several recent reports detailed descriptions of the geology and lithostratigraphy of the SRS and A/M Area (Gordon, 1982; Christensen and Gordon, 1983; Fallaw and Sargent, 1982; 
Colquhoun and others, 1983; Marine and Bledsoe, 1984; Logan and Euler, 1989; Fallaw and others, 1990; Aadland and others, 1991; Snipes, 1991; Fallaw and Price, 1992; Lewis and Aadland, 1992; Lewis and Aadland, 1994; Aadland and others, 1995b; and Fallaw and Price, 1995). The current study utilizes the lithostratigraphic nomenclature presented in Fallaw and Price (1995).

\subsubsection{Hydrostratigraphy}

The hydrostratigraphy of the SRS has been the subject of several different systems of hydrostratigraphic classification. This report incorporates the hydrostratigraphic nomenclature currently established for the SRS region and A/M Area by Aadland and others (1995a, 1995b). The informal hydrostratigraphic zones as defined by Eddy and others (1991) are used for the vadose zone. This study focuses on the up-dip part of the Floridan-Midville aquifer system as defined for A/M Area by Aadland and others (1995b). Strata of the Floridan-Midville aquifer system that exhibit internally consistent hydraulic characteristics and which, on a local scale, behave as distinct hydrostratigraphic units, are delineated as informal aquifer and confining zones (Aadland and others, 1995b). Figure 1-3 correlates the nomenclature of Aadland and others (1995b) and Eddy and others (1991) with the lithostratigraphy of Fallaw and Price (1995).

The hydrostratigraphy of A/M Area includes three aquifers of the Floridan-Midville aquifer system divided by one confining unit and one confining system. The Floridan-Midville aquifer system includes, in descending order, the McQueen Branch aquifer, the Crouch Branch aquifer, and the Steed Pond aquifer. The Crouch Branch aquifer (CBA) is the principal waterproducing aquifer at SRS and is the deepest unit that is sampled by the current monitoring well system. The current study focuses on the units within the Steed Pond aquifer and the vadose zone.

\subsubsection{Crouch Branch Confining Unit}

The Crouch Branch confining unit (CBCU) separates the Crouch Branch aquifer from the Steed Pond aquifer. The CBCU may be divided into three hydrogeologic zones beneath the A/M Area (Aadland and others, 1995b). These zones, in descending order, are the "upper clay" confining zone, the "middle sand" aquifer zone, and the "lower clay" confining zone.

In the western part of the A/M Area, the sand beds that constitute the "middle sand" aquifer zone are very thin or absent. In this area, the CBCU is not differentiated. In the northeastern part of the area, the clay beds of the "upper clay" and "lower clay" zone of the unit are thin or 
absent and groundwater flows between the Steed Pond and Crouch Branch aquifers (Aadland and others, 1995b). These clay beds are effectively absent at the north margin of A/M Area, and here the "middle sand" aquifer zone coalesces with the overlying "Lost Lake" aquifer zone of the Steed Pond aquifer.

\subsubsection{Steed Pond Aquifer}

The Steed Pond Aquifer consists primarily of interbedded sand and clayey sand. The Steed Pond aquifer is divided into the "M Area" aquifer zone, "green clay" confining zone, and "Lost Lake" aquifer zone. In areas where the "green clay" confining zone is absent, the "M Area" aquifer zone coalesces with the "Lost Lake" aquifer zone and is referred to as the undifferentiated Steed Pond aquifer (Aadland and others, 1995b).

"Lost Lake" aquifer zone. The "Lost Lake" aquifer zone (LLAZ) consists of yellow, tan, orange, and brown, loose to slightly indurated, fine to coarse, moderately to well-sorted, occasionally pebbly sand with minor amounts of clayey sand.

"Green Clay" confining zone. The "green clay" confining zone (GCCZ) overlies the LLAZ. This zone is considered to be correlative with the clay and silty clay beds of the Gordon confining unit of the Floridan aquifer system in the area south of Upper Three Runs (Aadland and others, 1995b). In the A/M Area the GCCZ consists of primarily orange and yellow, fine to coarse-grained, poorly to well-sorted sand and clayey sand interbedded with gray, green, and tan beds of clay and silty clay (Fallaw and Price, 1992). Aadland and others (1995b) consider these clay and silty clay beds to constitute the GCCZ in areas where they are sufficiently thick and continuous.

"M Area" aquifer zone. The "M Area" aquifer zone (MAAZ) extends from the water table to the top of the GCCZ. In A/M Area the MAAZ consists of orange to tan and yellow, fine to coarse, poorly to well-sorted sand of the Tobacco Road, Dry Branch and Santee Formations (Aadland and others, 1995b, Fallaw and Price, 1992). Pebbly layers, interbedded clay laminae, and clay interbeds (up to 8 feet in thickness) are common.

\subsubsection{Vadose Zone}

The vadose zone beneath $\mathrm{A} / \mathrm{M}$ Area contains several clay layers of local hydrologic and significance. The individual clay layers within these intervals are neither exceptionally thick nor laterally extensive, but are considered a significant factor in controlling movement of DNAPL through the vadose zone. 
Eddy and others, (1991) delineated four of these intervals which they referred to as "semiconfining/confining zones" beneath the integrated demonstration site. These intervals include the "200-foot clay", "270-foot clay", "300-foot clay" and the "325-foot clay". The intervals are informally named by the approximate elevations of their upper boundaries. The "200-foot clay" of Eddy and others (1991) is equivalent to the GCCZ of the Steed Pond aquifer later delineated by Aadland and others (1995b).

Each of these intervals represents a discrete depositional sequence. During the current study, it was realized that an additional interval, the "230-foot clay", should be added to the four intervals identified by Eddy and others (1991). This interval was identified by Jackson and others (1996) as containing a clay layer that has a profound influence on DNAPL migration below $\mathrm{A} / \mathrm{M}$-Area. In previous reports, this interval has been included as a lower layer within the "270-foot clay".

The "200-foot clay" as described by Eddy and others (1991) is relatively continuous across the study area. It becomes thin in the northern part of the study area and often contains trace amounts of glauconitie in the southern part of the study area.

The "230-foot clay" commonly rests near the water table and extends down into the water table where the clay is thick. Its distribution is sporadic and the thickness varies between zero to 41 feet. The clay is typically light yellowish green to yellowish orange with interbedded fine sand. Cores taken from within this interval commonly contain sponge spicules and evidence of silica replacement. This interval contains sporadically distributed interbeds of fine shell material. The clay within this interval is important because it is the last layer in the vadose zone preventing DNAPL from reaching the MAAZ. A thick clay layer is present in some cores and is often interbedded with silica-cemented sand.

The "270-foot clay" is roughly equivalent to the "tan clay" confining zone as defined in the General Separations Area (GSA) by Aadland and others (1995a). The "325-foot clay" consists of multiple layers of sand and clay and is typically dark purple to light grayish purple in color. 


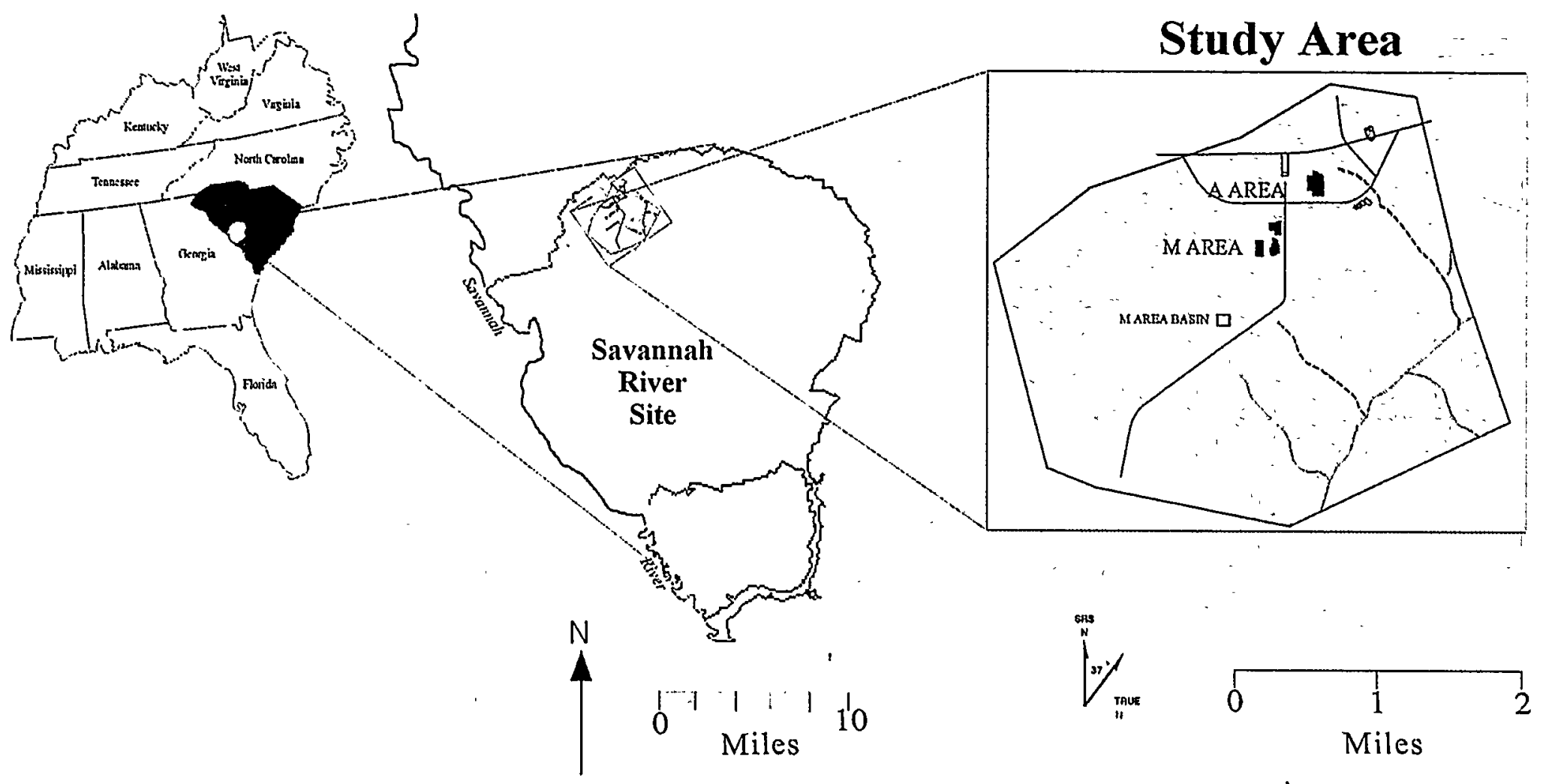

Figure 1-1. Location of the Savannah River Site and A/M Area 
Topography of the A/M Area and Study Area Boundary

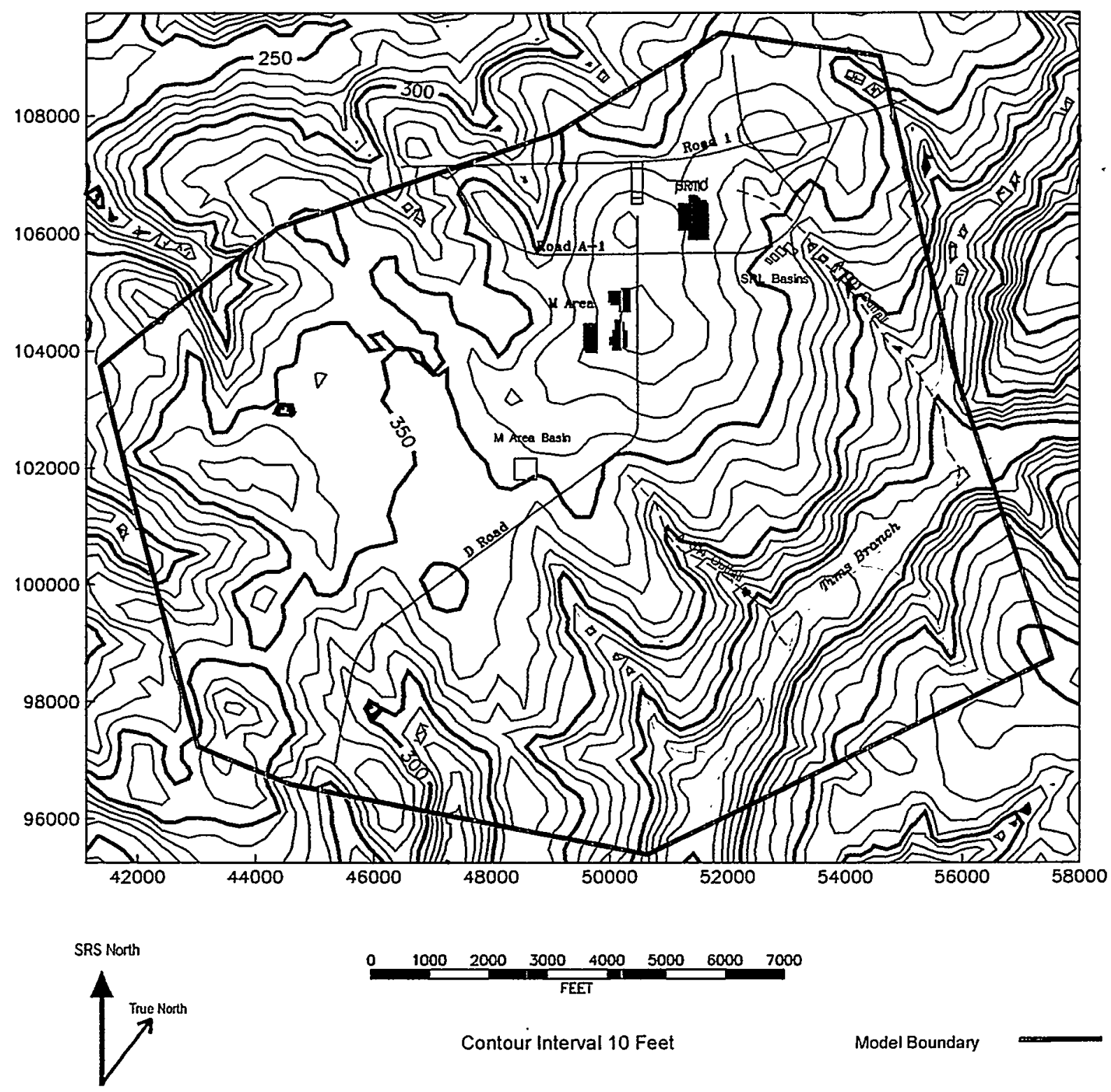

Figure 1-2. Topography of the A/M Area and Study Area Boundary 


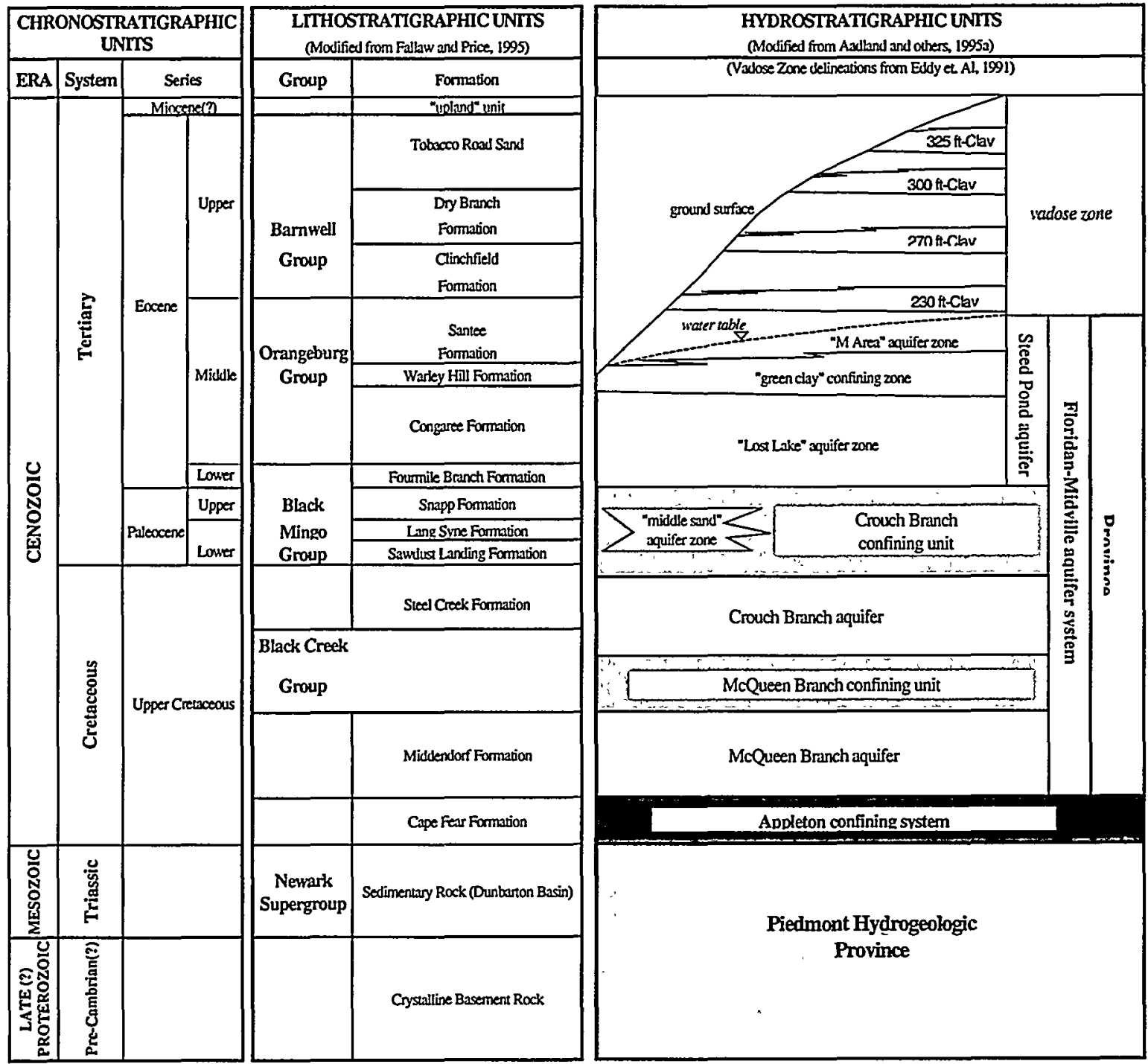

Figure 1-3. Comparison of Lithostratigraphic and Hydrostratigraphic Units beneath A/M Area at SRS 
This page intentionally left blank 


\subsection{METHODS}

Data utilized in this study include SRS coordinates, elevations, geophysical logs, and drill-core descriptions. The study utilized down-hole geophysical data including caliper, gamma ray, and resistivity logs for delineating aquifer and confining units and for correlating specific horizons.

\subsection{Data Collection}

This study utilized data from 83 continuous cores drilled in $A / M$ Area (Figure 2-1, Table 2-1). The quality requirements of this study included an internally consistent set of data. This required that the core descriptions be consistent so that similar horizons could be readily identified and correlated. All of the cores were taken during the period since 1988 and were described on a foot-by-foot basis in the SRS Core Laboratory by geologists working under the same Quality Assurance and Quality Control (QA/QC) program. All geologists were trained by an experienced geologist to procedure ESSOP-2-15 (WSRC, 1990). This was a formal training session, which outlined the procedure and specified the $\mathrm{QA} / \mathrm{QC}$ requirements.

The geologist estimates for percent of gravel, sand, and mud were periodically checked for accuracy by performing sieve analysis on selected samples. The descriptive estimates were compared to the actual sieve analysis results to maintain accurate descriptions. The geologist also described duplicate intervals to ensured internal consistency between individual descriptions. This ensured that percentage estimates were consistent between individual geologist and consistent with the measured results of sieve testing. This process developed a core logging geologist with highly accurate percentage estimates.

The process for selection of the cores was two-fold. Initially, all of the cores drilled within the $\mathrm{A} / \mathrm{M}$ area were considered. However, due to the poor condition of many of the older cores, the relatively shallow depth of penetration, and poor core recovery, many of these were eliminated from consideration for use in this study. Criteria for the final core selection was based on:

total depth drilled;

overall core recovery and cored intervals;

consistency of core description;

geographic location; 
current condition of the core;

availability and quality of geophysical logs.

It was considered extremely important that the cores penetrate the GCCZ for delineation of the vertical and lateral extent of fine-grained sediments within this unit. Some of the cores used in this study were drilled as soil borings for exploratory purposes and the resulting boreholes were not completed as monitoring wells. Because of this, many of the core locations have only been documented in field activities reports for the soil boring installations. Some of the coordinates provided in these reports are preliminary, pre-drill locations (stake out). Based on this study, the pre-drill locations should be validated. This study deferred to the core locations provided in Appendix C of Aadland and others (1995b). The locations of cores drilled after 1995 were taken from field activities reports or sources. Table 2-2 lists the source for each core location.

The core descriptions used in this study are included as Appendix A to this report. All core samples have been described following procedure ESSOP-2-15 (WSRC, 1990). A summary of the core description format is included as Appendix B.

\subsection{Data Qualification}

A rigorous Quality Review of the data was performed, comparing the core descriptions and geophysical logs with the list of unit boundaries. Geologists made refinements to these boundaries to ensure internal consistency between the unit boundaries and the lithology of the hydrostratigraphic units.

\subsection{Database Structure}

A relational database was constructed for this project using Paradox ${ }^{\circledast}$ (version 7.0) software. All geological and hydrological data were collected for the $\mathrm{A} / \mathrm{M}$ Area and entered into the database. Measured values were integrated with the hydrostratigraphic "picks" to create data output files to meet EarthVision ${ }^{\circledR}$ format and content requirements. The database is constructed so that revisions made to the subjective data (hydrostratigraphic "picks") are documented. The database records and dates each revision to the picked boundaries, and automatically regenerates updated output files for re-loading into EarthVision ${ }^{\oplus}$. This aspect of the database facilitates data evaluation and revision, and provides a means by which to maintain a history of the subjective data set. 


\section{$2.4 \quad$ Hydrogeologic Model}

\subsubsection{Hydrostratigraphic Methods}

Hydrostratigraphic boundaries for cores are determined through evaluation of several factors. Gamma-ray logs are used in combination with resistivity logs to evaluate the potential confining properties of the strata. In general, low resistivity and high gamma-ray values indicate clay-rich sediment that impedes the flow of ground water. Core descriptions are used (in conjunction with the geophysical logs) to select boundaries between units. If core recovery is good, the foot-by-foot description is an excellent tool for identifying the erosional surfaces and fining-upward depositional sequences that mark the contacts between the intervals. The log patterns were used in conjunction with the geologic descriptions to correlate the boundaries from core to core.

The hydrostratigraphic methodology employed by the current study incorporates the method used by WSRC (1998) for identifying interval boundaries within the CBCU. Each interval addressed in this study is delineated by a separate sedimentary sequence, bounded above and below by surfaces of deposition. The intervals can be generally described as fining-upward sequences that typically include coarse and medium-grained sand with minor to moderate amounts of gravel at the base that grades upward into medium-grained sand, sandy silt, and clay. The composite $\log$ in Figure 2-2 illustrates the typical lithologic variations and stratigraphic relationships between the intervals within the context of geological and geophysical data.

The results of WSRC (1998) did not include identifying boundaries of this type for the tops of the LLAZ and the GCCZ. The conceptual hydrostratigraphic model presented in WSRC (1998) included boundaries for the LLAZ and GCCZ that were identified strictly on the basis of contrasting lithologic parameters such as clay content and porosity. At the time, this method was considered appropriate at the scale of the model that was being constructed. The current study is intended to supplement the work presented in WSRC (1998). Boundaries for the LLAZ and GCCZ are therefore re-defined herein using the "depositional sequence" method described above.

Clay balls proved to be an especially useful feature for identifying interval boundaries for the current study. The coarse-grained sediment found at the base of the fining-upward sequences commonly contains clay balls with a lithology similar to that of the fine-grained sediment at 
the top of the sequence in the underlying interval. These clay balls are interpreted to be rip-up clasts that are derived from material in the underlying interval.

The base of the GCCZ is marked by silty medium-grained sand and pebbly sand that lies on the better sorted and more finely grained sand of the LLAZ. The base of the GCCZ commonly appears on geophysical logs as an abrupt increase in the gamma-ray counts. The gamma-ray pattern within the GCCZ is generally much more "blocky" than that in the LLAZ (Figure 2-2).

The "230-foot clay" has a texture and color distinctively different from the "270-foot clay". The interval typically contains sponge spicules and zones of siliceous cement. Individual clay layers have a waxy luster. The base of the " 230 -foot clay" is picked where there is a noticeable decrease in the gamma-ray counts from those in the GCCZ. Overall, the interval exhibits much lower gamma-ray activity and is characterized by a relatively "flat" gamma-ray curve.

The "270-foot clay" has a sporadic gamma-ray count and resistivity signature. The lithology is typically interbedded sands and clay. The base of the "270-foot clay" is marked by prominent spike on gamma-ray logs, which corresponds with an increase in overall grain size and a decrease in sorting of the sediment.

The "300-foot clay" is typically dark yellowish orange to moderate yellowish brown in color. Resistivity values on geophysical logs of this interval are generally low but tend to increase near the contact with the overlying " 325 -foot clay". The base of the " 300 -foot clay" is picked where the gamma-ray values begin to increase from the baseline values in the "270-foot clay". The lithology of this interval varies from sand to clay.

The "325-foot clay" is typically dark yellowish orange to dark purple in color. The sediment within this interval grades from medium-grained sand into sandy silt near the top of the interval. In some cores, the sandy silt grades into well-compacted, silty clay. The base of the " 325 -foot clay" is commonly marked by a peak on the gamma ray curve and an increase in the amount of gravel-sized material (Figure 2-2).

The base of the "undifferentiated soils" unit is distinguished by the presence of purple clay balls and a sharp increase in the natural gamma response (Figure 2-2). The lithology varies from sand to clay.

"Picked" tops for the hydrostratigraphic units are tabulated in Table 2-3. Thicknesses for these units are summarized in Table 2-4. 


\subsubsection{Two-Dimensional Grid Calculation}

The database was used to prepare a hydrogeologic model of the $\mathrm{A} / \mathrm{M}$ Area. The model was constructed with EarthVision ${ }^{\circledR}$ software. EarthVision ${ }^{\circledR}$ processes sets of spatial and property data by calculating minimum-tension grids to contour a "best fit" of the data. The grids can contour data in three dimensions $(x, y, z)$, such as the top of a geologic unit, as twodimensional grids, or contour data in 4-dimensions: $x, y, z$, and a "property." An example of a property might be the variation of the percentage of mud within a geologic unit.

Data for the unit tops and interval horizons were exported from the Paradox ${ }^{\circledR}$ database into EarthVision ${ }^{\circledR}$. After minor format changes, the data was processed by the EarthVision ${ }^{\circledR}$ minimum-tension gridding algorithm, producing a two-dimensional grid of the horizon.

The EarthVision ${ }^{\circledR}$ model utilizes digitized $\mathrm{x}, \mathrm{y}, \mathrm{z}$ data for all United States Geological Survey (USGS) topographic coverage of the A/M Area. The data originate from USGS digital elevation model (DEM) data files. The DEM data are processed in the same manner as the data for the unit boundaries to produce a grid representing the topography of the study area. The high density of data points in this data set produced a two-dimensional grid of exceptional accuracy and detail. This grid was then used in subsequent two-dimensional and threedimensional gridding to determine the extent of hydrostratigraphic units that crop out in the study area.

\subsubsection{Three-Dimensional Grid Calculation}

The property data processed by EarthVision ${ }^{\circledR}$ consisted of the foot-by-foot lithologic descriptions made from continuous core samples taken from the $\mathrm{A} / \mathrm{M}$ Area. Lithologic data was exported from the Paradox ${ }^{\circledast}$ database and formatted for use in the EarthVision ${ }^{\circledR}$ threedimensional Minimum-Tension Gridding module. The EarthVision ${ }^{\otimes}$ software allows a wide variety of options in how the three-dimensional grids are calculated. The lithology was first processed using the two-dimensional grids of the lithostratigraphic units as limiting surfaces. This effectively prevented the model from "seeing" any lithologic information from outside the lithostratigraphic interval during the gridding process. The gridding algorithm then calculated "best fits" for the lithologic property within each lithostratigraphic unit using only the data from within the unit as delineated by the geologist and gridded by EarthVision ${ }^{\circledR}$. This technique produces a property model of the hydrogeology that is consistent with the unit boundaries. A model built in this manner will be more accurate for hydrogeologic analysis and groundwater modeling. 


\subsubsection{Mapping}

Altitude Contour Maps, Isopach Maps and Lithofacies Maps were generated using EarthVision ${ }^{\circledR}$ software.

\subsubsection{Altitude Contour Maps}

Altitude contour maps were constructed for each hydrostratigraphic unit using the twodimensional grids that were calculated from the scattered data for the unit tops. The maps are plotted using the Contour and Basemap module of EarthVision ${ }^{\circledR}$. Contour intervals are chosen by individual data set so as to convey the information clearly and concisely, but virtually any level of detail is possible. An effort was made to keep the contour interval to within one-tenth of the range of the $z$-values. This serves to minimize the number of contour lines, yet generally maintains a level of detail suitable for interpretation of the map.

\subsubsection{Isopach Maps}

Two-dimensional grids of unit thickness (isopach grids) were calculated by first comparing the two-dimensional grids of the unit base and unit top with the two-dimensional grid of the topography. Isopach maps of vertical unit thickness were calculated from comparison of the two-dimensional grids of the unit base and unit top. A value was then written to the corresponding nodes of the resultant grid (the isopach grid) equal to the vertical distance between the base and upper surface of the unit.

The resultant two-dimensional isopach grids were contoured using EarthVision ${ }^{\circledR}$ in the same fashion as the structure-contour maps.

\subsubsection{Lithofacies Maps}

Lithofacies maps were created to depict the lateral distribution of mud and the internal variation of the mud content within the unit. Maps of the geometric mean and standard deviation of the mud content were created from the property data in the three-dimensional grids for each of the intervals. EarthVision ${ }^{\circledR}$ 's Formula Processor calculated (vertically) the geometric mean and standard deviation of the mud percentages within the unit at each grid node. These calculations produced two-dimensional grids, which are expressed as maps to illustrate the lateral distribution of the mean, and the internal variation of the mean within the interval. The maps of the mean express the overall mud content within the unit. The maps of the standard deviation give an indication of the degree of vertical lithologic variation, such as 
interbedding of sediment types. Both of these lithofacies parameters are functions of the thickness of the unit. Analyses made using these lithofacies maps must therefore consider the geometry depicted by the isopach maps. 


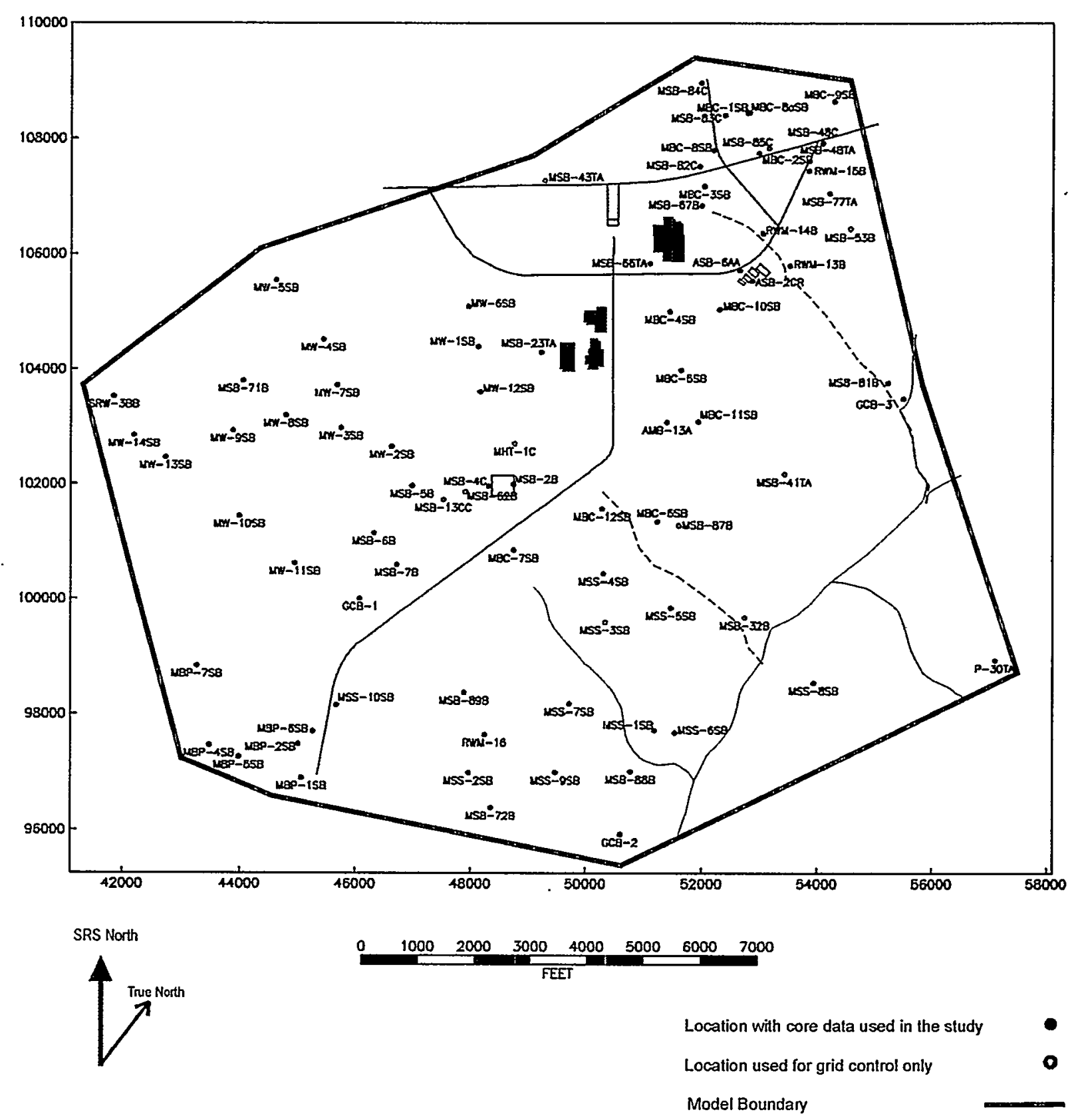

Figure 2-1. Locations of Cores Used in the Study 


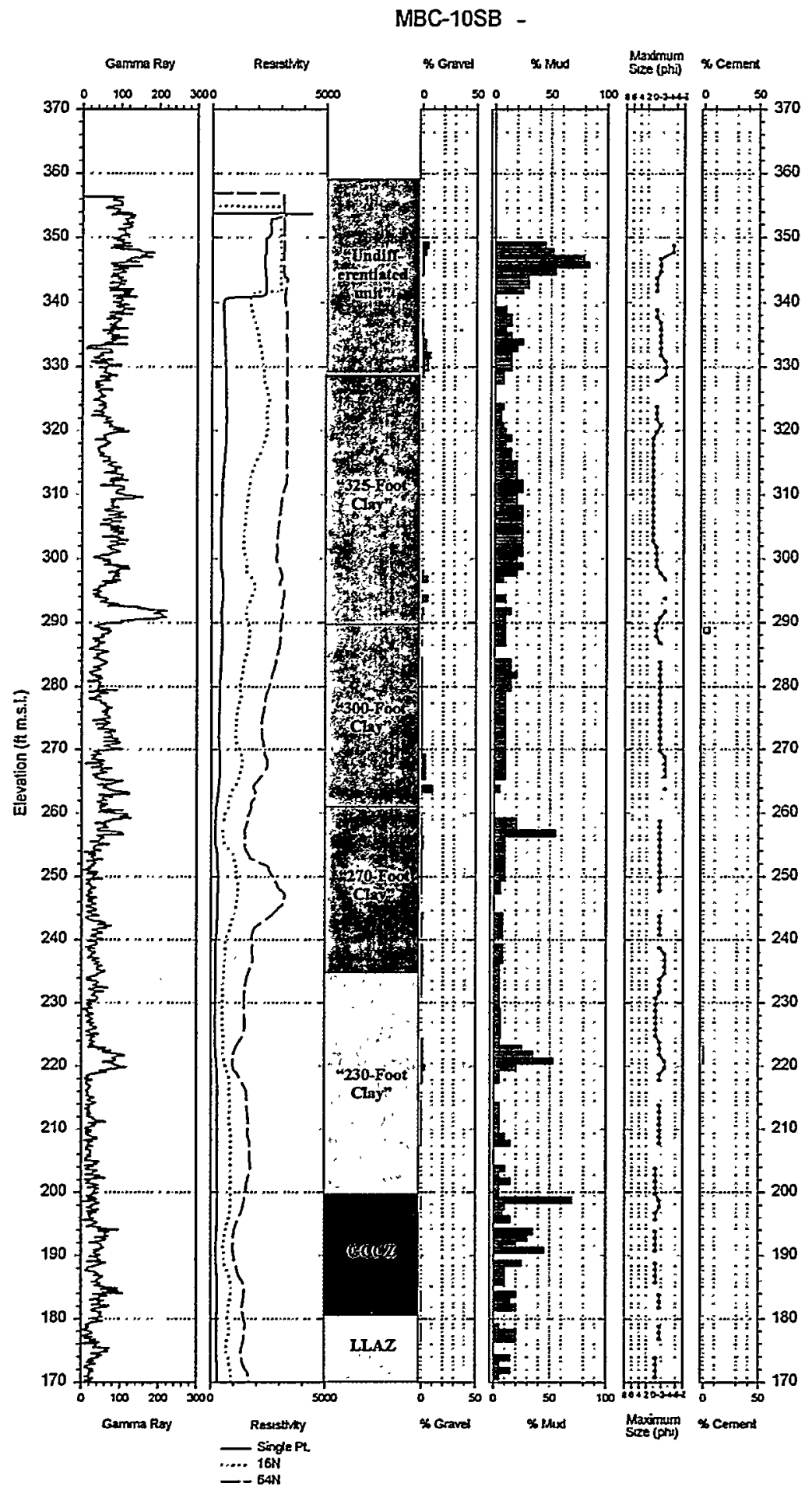

Figure 2-2. Composite Lithologic Log for SRS Core MBC-10SB 


\section{Table 2-1. Summary of Cored Intervals}

\begin{tabular}{|c|c|c|c|c|}
\hline \multirow[b]{2}{*}{ Core $\mathbf{D D}$} & \multicolumn{2}{|c|}{$\begin{array}{c}\text { Cored Interval (ft } \\
\text { bgl) }\end{array}$} & \multirow[b]{2}{*}{ Recovery (\%) } & \multirow[b]{2}{*}{ Remarks } \\
\hline & Top & Bottom & & \\
\hline AMB-4A & 1 & 285 & 78 & \\
\hline AMB-7A & 1 & 283 & 42 & \\
\hline AMB-10A & 1 & 270 & 59 & \\
\hline AMB-11B & 1 & 219 & 42 & \\
\hline AMB-13A & 1 & 281 & 51 & \\
\hline AMB-18A & 1 & 270 & 79 & \\
\hline ASB-2CR & 1 & 378 & 60 & \\
\hline ASB-5C & 1 & 375 & 68 & \\
\hline ASB-6AA & 1 & 290 & 75 & \\
\hline ASB-10C & 1 & 216 & 73 & \\
\hline GCB-1 & 10 & 300 & 86 & \\
\hline GCB-2 & 1 & 230 & 67 & \\
\hline GCB-3 & 1 & 200 & 82 & \\
\hline MBC-1SB & 1 & 365 & 78 & $\begin{array}{l}\text { Geophysical log for this core is labeled "MSB-CB1". The core name was } \\
\text { modified to conform with the format required by ESSOP-2-15. }\end{array}$ \\
\hline $\mathrm{MBC}-2 \mathrm{SB}$ & 1 & 365 & 79 & $\begin{array}{l}\text { Geophysical log labeled "MSB-CB2". The core name was miodified to } \\
\text { conform with the format required by ESSOP-2-15. }\end{array}$ \\
\hline MBC-3SB & 1 & 270 & 87 & $\begin{array}{l}\text { Field Geologic log labeled "MBCSB-3". The core name was modified to } \\
\text { conform with the format required by ESSOP-2-15. }\end{array}$ \\
\hline $\mathrm{MBC}-4 \mathrm{SB}$ & 1 & 365 & 82 & $\begin{array}{l}\text { Geophysical log labeled "MBCSB-4n. The core name was modified to conform } \\
\text { with the format required by ESSOP-2-15. }\end{array}$ \\
\hline MBC-5SB & 1 & 365 & 67 & $\begin{array}{l}\text { Geophysical log labeled "MBCSB-5". The core name was modified to conform } \\
\text { with the format required by ESSOP-2-15. }\end{array}$ \\
\hline MBC-6SB & 1 & 365 & 75 & $\begin{array}{l}\text { Geophysical log labeled "MBCSB-6". The core name was modified to conform } \\
\text { with the format required by ESSOP-2-15. }\end{array}$ \\
\hline MBC-7SB & 1 & 365 & 76 & $\begin{array}{l}\text { Geophysical log labeled "MBCSB-7". The core name was modified to conform } \\
\text { with the format required by ESSOP-2-15. }\end{array}$ \\
\hline MBC-8SB & 1 & 210 & 86 & $\begin{array}{l}\text { Field Geologic log labeled "MCBSB-8". The core name was modified to } \\
\text { conform with the format required by ESSOP-2-15. }\end{array}$ \\
\hline MBC-8aSB & 1 & 780 & 53 & $\begin{array}{l}\text { Field Geologic log labeled "MCBSB-8A". The core name was modified to } \\
\text { conform with the format required by ESSOP-2-15. }\end{array}$ \\
\hline MBC-9SB & 1 & 347 & 78 & $\begin{array}{l}\text { Field Geologic log labeled "MCBSB-9". The core name was modified to } \\
\text { conform with the format required by ESSOP-2-15. }\end{array}$ \\
\hline
\end{tabular}




\section{Table 2-1. Summary of Cored Intervals (Continued)}

\begin{tabular}{|c|c|c|c|c|}
\hline \multirow[b]{2}{*}{ Core ID } & \multicolumn{2}{|c|}{$\begin{array}{c}\text { Cored Interval (ft } \\
\text { bgl) }\end{array}$} & \multirow[b]{2}{*}{ Recovery (\%) } & \multirow[b]{2}{*}{ Remarks } \\
\hline & Top & Bottom & & \\
\hline $\mathrm{MBC}-10 \mathrm{SB}$ & 1 & 607 & 85 & $\begin{array}{l}\text { No geophysical log or Field Geologic log for this core. The core name was } \\
\text { modified to conform with the format required by ESSOP-2-15. }\end{array}$ \\
\hline MBC-11SB & 1 & 347 & 81 & $\begin{array}{l}\text { Geophysical log labeled "MCBSB-11". The core name was-modified to } \\
\text { conform with the format required by ESSOP-2-15. }\end{array}$ \\
\hline $\mathrm{MBC}-12 \mathrm{SB}$ & 1 & 607 & 88 & $\begin{array}{l}\text { Geophysical log labeled "MCBSB-12". The core name was modified to } \\
\text { conform with the format required by ESSOP-2-15. }\end{array}$ \\
\hline MBP-1SB & 1 & 350 & 81 & $\begin{array}{l}\text { Geophysical log labeled "MCB/MBP-CH-01". The core name was modified to } \\
\text { conform with the format required by ESSOP-2-15. }\end{array}$ \\
\hline MBP-2SB & 1 & 345 & 88 & $\begin{array}{l}\text { Geophysical log labeled "MCB/MBP-CH-02". The core name was modified to } \\
\text { conform with the format required by ESSOP-2-15. }\end{array}$ \\
\hline MBP-4SB & 1 & 300 & 85 & $\begin{array}{l}\text { Geophysical log labeled "MCBMBP-CH- } 04 \text { ". The core name was modified to } \\
\text { conform with the format required by ESSOP-2-15. }\end{array}$ \\
\hline MBP-5SB & 1 & 335 & 87 & $\begin{array}{l}\text { Geophysical log labeled "MCBMBP-CH-05". The core name was modified to } \\
\text { conform with the format required by ESSOP-2-15. }\end{array}$ \\
\hline MBP-6SB & 81 & 378 & 88 & $\begin{array}{l}\text { Geophysical log labeled "MCB/MBP-CH-O6". The core name was modified to } \\
\text { conform with the format required by ESSOP-2-15. }\end{array}$ \\
\hline MBP-7SB & 131 & 350 & 79 & $\begin{array}{l}\text { Geophysical log labeled "MCB/MBP-CH-07". The core name was modified to } \\
\text { conform with the format required by ESSOP-2-15. }\end{array}$ \\
\hline MHT-12C & 1 & 120 & 90 & \\
\hline MHT-20C & 1 & 200 & 93 & . \\
\hline MSB-1C & 1 . & 203 & 82 & \\
\hline MSB-2B & 1 & 300 & 74 & . \\
\hline MSB-3B & 1 & 233 & 82 & \\
\hline MSB-4C & 1 & 208 & 81 & \\
\hline MSB-5B & 101 & 225 & 70 & \\
\hline MSB-6B & 101 & 216 & 68 & \\
\hline MSB-7B & 1 & 211 & 79 & \\
\hline MSB-23TA & 286 & 345 & 78 & \\
\hline MSB-32B & 1 & 180 & 63 & \\
\hline $\mathrm{MSB}-48 \mathrm{C}$ & 1 & 203 & 76 & \\
\hline MSB-62B & 1 & 220 & 80 & \\
\hline MSB-66TA & 1 & 351 & 82 & \\
\hline MSB-67B & 1 & 280 & 75 & \\
\hline
\end{tabular}


Table 2-1. Summary of Cored Intervals (Continued)

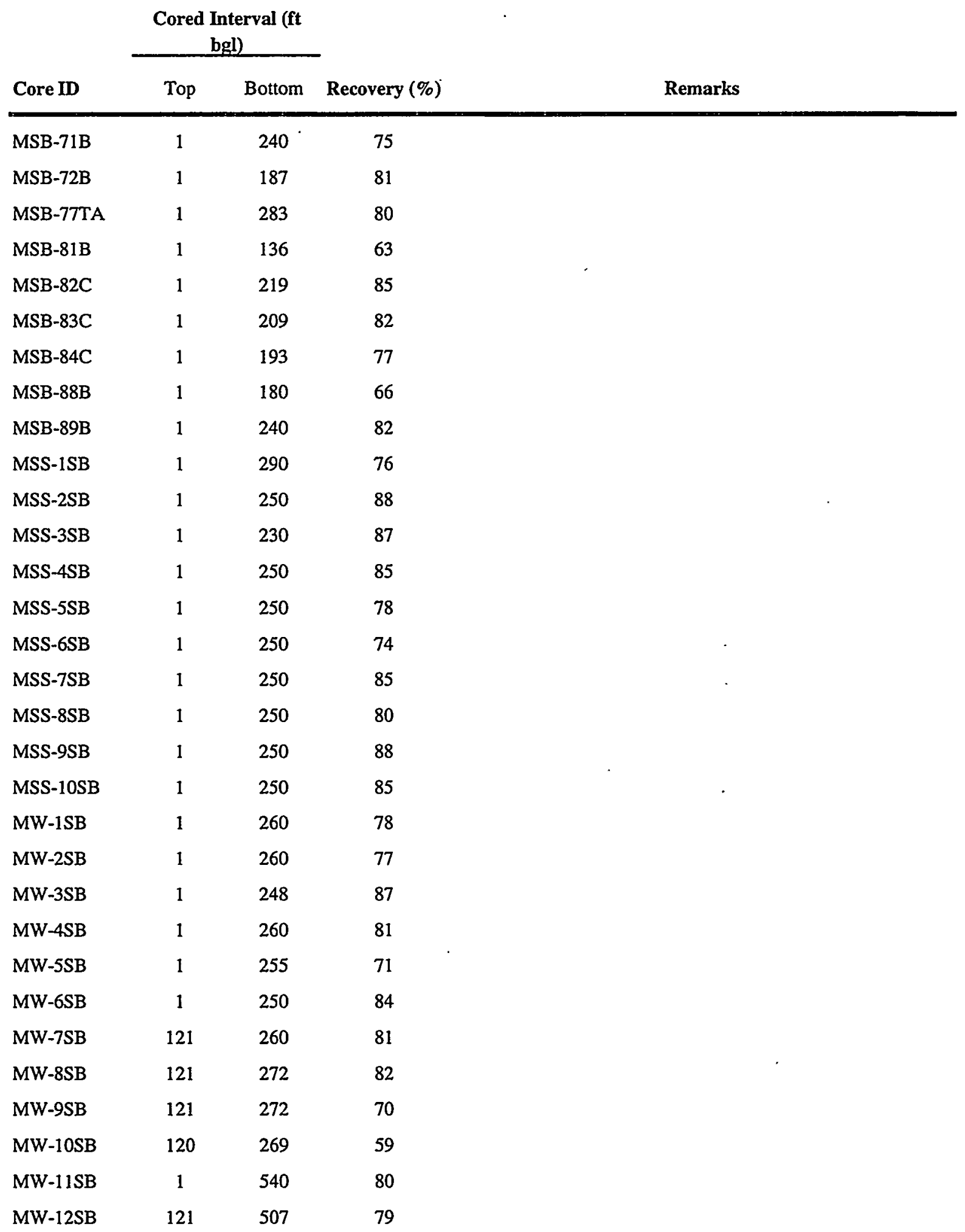


Table 2-1. Summary of Cored Intervals (Continued)

\begin{tabular}{lcccc} 
& \multicolumn{2}{c}{ Cored Interval (ft } \\
bgl) & & & \\
\cline { 2 - 3 } Core ID & Top & Bottom & Recovery (\%) & Remarks \\
\hline MW-13SB & 121 & 308 & 68 \\
MW-14SB & 1 & 515 & 52 \\
RWM-13B & 1 & 258 & 90 \\
RWM-14B & 1 & 247 & 81 \\
RWM-16 & 1 & 224 & 76 \\
SRW-3BB & 1 & 340 & 86 & \\
\hline
\end{tabular}




\section{Table 2-2. Coordinates of Core Locations}

SRS Easting SRS Northing Grnd. Surface

\begin{tabular}{|c|c|c|c|c|}
\hline Core ID & (ft) & (ft) & Elevation ( $\mathrm{ft} \mathbf{m s l}$ ) & Reference \\
\hline AMB-13A & 51396 & 103082 & 362.9 & WSRC, 1996b \\
\hline ASB-2CR & 52862.7 & 105540.2 & 353.1 & WSRC, 1996b \\
\hline ASB-6AA & 52643.9 & 105727 & 351.8 & WSRC, 1996b \\
\hline GCB-1 & 46074.39 & 100006.75 & 335.8 & Schlumberger, 1996a \\
\hline GCB-2 & 50599.7 & 95924.9 & 221 & Schlumberger, 1996b \\
\hline GCB-3 & 55502.72 & 103488.45 & 255.7 & Western-Atlas, 1996 \\
\hline MBC-1SB & 52780 & 108450 & 371.8 & Aadland and others, $1995 \mathrm{~b}$ \\
\hline MBC-2SB & 52975 & 107750 & 379.8 & Aadland and others, $1995 \mathrm{~b}$ \\
\hline MBC-3SB & 52035 & 107178 & 366.8 & Aadland and others, $1995 \mathrm{~b}$ \\
\hline $\mathrm{MBC}-4 \mathrm{SB}$ & 51445 & 105008 & 380.8 & Aadland and others, $1995 \mathrm{~b}$ \\
\hline $\mathrm{MBC}-5 \mathrm{SB}$ & 51641 & 103983 & 370.8 & Aadland and others, $1995 \mathrm{~b}$ \\
\hline $\mathrm{MBC}-6 \mathrm{SB}$ & 51234.5 & 101346.4 & 326.8 & WSRC, 1997 \\
\hline $\mathrm{MBC}-7 \mathrm{SB}$ & 48750 & 100850 & 328.8 & Aadland and others, $1995 \mathrm{~b}$ \\
\hline MBC-8SB & 52189.41 & 107798.58 & 380 & Aadland and others, $1995 \mathrm{~b}$ \\
\hline MBC-8aSB & 52807.78 & 108457.57 & 371.8 & WSRC, 1997 \\
\hline MBC-9SB & 54286.4 & 108646.7 & 349.8 & Aadland and others, $1995 \mathrm{~b}$ \\
\hline MBC-10SB & 52302.92 & 105042 & 359.8 & Aadland and others, $1995 \mathrm{~b}$ \\
\hline $\mathrm{MBC}-11 \mathrm{SB}$ & 51937.25 & 103090.5 & 360.8 & Aadland and others, $1995 \mathrm{~b}$ \\
\hline $\mathrm{MBC}-12 \mathrm{SB}$ & 50284.19 & 101570.5 & 336.8 & Aadland and others, $1995 \mathrm{~b}$ \\
\hline MBP-1SB & 45069 & 96903 & 317.8 & WSRC, 1996b \\
\hline MBP-2SB & 45012 & 97490 & 336.7 & WSRC, 1996b \\
\hline MBP-4SB & 43476 & 97469 & 372.7 & WSRC, 1996b \\
\hline MBP-5SB & 43986 & 97264 & 360.5 & WSRC, 1996b \\
\hline MBP-6SB & 45264 & 97705 & 318.7 & WSRC, 1996b \\
\hline MBP-7SB & 43264 & 98839 & 345 & WSRC, 1996b \\
\hline MHT-1C & 48765.6 & 102706.8 & 362.7 & WSRC, 1996a \\
\hline MSB-2B & 48748.2 & 101997.9 & 352.3 & WSRC, 1996a \\
\hline MSB-4C & 48313.6 & 101963.2 & 353.1 & WSRC, 1996a \\
\hline MSB-5B & 46983.6 & 101971.1 & 343.1 & WSRC, 1996a \\
\hline MSB-6B & 46321.6 & 101148.5 & 341.8 & WSRC, 1996a \\
\hline MSB-7B & 46718.1 & 100597.6 & 342.1 & WSRC, 1996a \\
\hline MSB-13CC & 47525.7 & 101728.8 & 344.8 & WSRC, 1996a \\
\hline MSB-23TA & 49225.8 & 104298.8 & 370.4 & WSRC, 1996a \\
\hline MSB-32B & 52742.5 & 99676 & 253.5 & WSRC, 1996a \\
\hline MSB-41TA & 53429.7 & 102176.5 & 321.7 & WSRC, 1996a \\
\hline MSB-43TA & 49281.8 & 107275.8 & 355.3 & WSRC, 1996a \\
\hline MSB-48C & 54077 & 107917.5 & 360.2 & WSRC, 1996a \\
\hline
\end{tabular}


Table 2-2. Coordinates of Core Locations (Continued)

SRS Easting SRS Northing Grnd. Surface

\begin{tabular}{|c|c|c|c|c|}
\hline Core ID & $(\mathrm{ft})$ & (ft) & Elevation (ft msl) & Reference \\
\hline MSB-48TA & 54089.2 & 107925.8 & 359.8 & WSRC, 1996a \\
\hline MSB-53B & 54574.3 & 106443.6 & 342.3 & WSRC, 1996a \\
\hline MSB-62B & 47906.8 & 101865.3 & 347 & WSRC, 1996a \\
\hline MSB-66TA & 51096.7 . & 105842.6 & 380.5 & WSRC, 1996a \\
\hline MSB-67B & 51989.6 & 106842 & 362.7 & WSRC, 1996a \\
\hline MSB-71B & 44054.7 & 103801.6 & 342.9 & WSRC, 1996a \\
\hline MSB-72B & 48350.3 & 96387.6 & 326.7 & WSRC, 1996a \\
\hline MSB-77TA & 54208.9 & 107053.8 & 354.9 & WSRC, 1996a \\
\hline MSB-81B & 55230.4 & 103762.7 & 265.1 & WSRC, 1996a \\
\hline MSB-82C & 51949.4 & 107521.9 & 371.7 & WSRC, 1996a \\
\hline MSB-83C & 52384.7 & 108405.3 & 369.8 & WSRC, 1996a \\
\hline MSB-84C & 51973.7 & 108967.9 & 359.9 & WSRC, 1996a \\
\hline MSB-85C & 53151.4 & 107835.2 & 378.6 & WSRC, 1996a \\
\hline MSB-87B & 51607 & 101276 & 334 & WSRC, 1996a \\
\hline MSB-88B & 50774.2 & 97013 & 235.8 & WSRC, 1996a \\
\hline MSB-89B & 47889.9 & 98374.1 & 337.3 & WSRC, 1996a \\
\hline MSS-1SB & 51185.9 & 97717.7 & 261.8 & Aadland and others, $1995 \mathrm{~b}$ \\
\hline MSS-2SB & 47963.4 & 96992.1 & 298.8 & Aadland and others, $1995 \mathrm{~b}$ \\
\hline MSS-3SB & 50336.5 & 99594.2 & 318.8 & Aadland and others, $1995 \mathrm{~b}$ \\
\hline MSS-4SB & 50308.7 & 100442 & 337.8 & Aadland and others, $1995 \mathrm{~b}$ \\
\hline MSS-5SB & 51469.9 & 99842.9 & 304.8 & Aadland and others, $1995 \mathrm{~b}$ \\
\hline MSS-6SB & 51541 & 97682.9 & 252.8 & Aadland and others, $1995 \mathrm{~b}$ \\
\hline MSS-7SB & 49715.6 & 98180.6 & 297.8 & Aadland and others, $1995 \mathrm{~b}$ \\
\hline MSS-8SB & 53943.4 & 98545 & 283.8 & Aadland and others, $1995 \mathrm{~b}$ \\
\hline MSS-9SB & 49477.9 & 96996.9 & 316.8 & Aadland and others, $1995 \mathrm{~b}$ \\
\hline MSS-10SB & 45674 & 98159 & 305.8 & Aadland and others, $1995 \mathrm{~b}$ \\
\hline MW-1SB & 48128 & 104396 & 345.8 & Aadland and others, $1995 \mathrm{~b}$ \\
\hline $\mathrm{MW}-2 \mathrm{SB}$ & 46629 & 102653 & 347.8 & Aadland and others, $1995 \mathrm{~b}$ \\
\hline MW-3SB & 45752 & 102982 & 347.8 & Aadland and others, $1995 \mathrm{~b}$ \\
\hline $\mathrm{MW}-4 \mathrm{SB}$ & 45441 & 104523 & 350.8 & Aadland and others, $1995 \mathrm{~b}$ \\
\hline MW-5SB & 44618 & 105553 & 334.8 & Aadland and others, $1995 \mathrm{~b}$ \\
\hline MW-6SB & 47954 & 105098 & 337.8 & Aadland and others, $1995 \mathrm{~b}$ \\
\hline MW-7SB & 45680.41 & 103726.41 & 358 & WSRC, 1996b \\
\hline MW-8SB & 44790.4 & 103199.01 & 357.5 & WSRC, 1996b \\
\hline MW-9SB & 43880.29 & 102934.67 & 353.8 & WSRC, 1996b \\
\hline MW-10SB & 43994.16 & 101446.29 & 367.9 & WSRC, 1996b \\
\hline
\end{tabular}


Table 2-2. Coordinates of Core Locations (Continued) SRS Easting SRS Northing Grnd. Surface

\begin{tabular}{lrrrl} 
Core ID & \multicolumn{1}{c}{$(\mathbf{f t})$} & \multicolumn{1}{c}{$(\mathbf{f t})$} & Elevation (ft msl) & \multicolumn{1}{c}{ Reference } \\
\hline MW-11SB & 44951.23 & 100621.11 & 358.1 & WSRC, 1996b \\
MW-12SB & 48163.57 & 103608.04 & 348.4 & WSRC, 1996b \\
MW-13SB & 42730.26 & 102465.26 & 361.4 & WSRC, 1996b \\
MW-14SB & 42195.92 & 102846.99 & 341.5 & WSRC, 1996b \\
P-30TA & 57104.5 & 98933.3 & 355.1 & WSRC, 1996a \\
RWM-13B & 53516.3 & 105803.3 & 333.2 & WSRC, 1996a \\
RWM-14B & 53044.7 & 106362.1 & 348.5 & WSRC, 1996a \\
RWM-15B & 53849 & 107444.7 & 365.9 & WSRC, 1996a \\
RWM-16 & 48244.8 & 97647.2 & 318.4 & WSRC, 1996a \\
SRW-3BB & 41845.6 & 103526.6 & 330.3 & WSRC, 1996a \\
\hline
\end{tabular}


Table 2.3. Unit Boundaries and Interval Tops

\begin{tabular}{|c|c|c|c|c|c|c|c|}
\hline \multirow[b]{2}{*}{ Core $\mathbf{D}$} & \multirow{2}{*}{$\begin{array}{l}\text { Surface } \\
\text { Elevation } \\
\text { (ft msl) }\end{array}$} & \multirow[b]{2}{*}{$\begin{array}{l}\text { "325" } \\
\text { Clay }\end{array}$} & \multirow[b]{2}{*}{$\begin{array}{c}\text { "300" } \\
\text { Clay }\end{array}$} & \multirow[b]{2}{*}{$\begin{array}{l}\text { "270" } \\
\text { Clay }\end{array}$} & \multirow[b]{2}{*}{$\begin{array}{l}\text { "230" } \\
\text { Clay }\end{array}$} & \multicolumn{2}{|c|}{ Steed Pond Aquifer } \\
\hline & & & & & & GCCZ & LLAZ \\
\hline AMB-13A & 362.9 & 327.9 & 307.9 & 275.9 & 246.9 & 216.9 & 184.9 \\
\hline ASB-2CR & 353.1 & 333.1 & 305.1 & 263.1 & 240.1 & 205.1 & 186.1 \\
\hline ASB-6AA & 351.8 & 323.8 & 296.8 & 266.8 & 233.8 & 200.3 & 187.3 \\
\hline GCB-1 & 335.8 & 313.8 & 295.8 & 270.8 & 232.8 & 203.8 & 179.8 \\
\hline GCB-2 & 221 & abs & abs & abs & abs & abs & 166 \\
\hline GCB-3 & 255.7 & abs & abs & abs & 220.7 & 204.7 & 191.7 \\
\hline MBC-1SB & 371.8 & 352.8 & 291.8 & 251.8 & 221.8 & 196.8 & 184.8 \\
\hline $\mathrm{MBC}-2 \mathrm{SB}$ & 379.8 & 354.8 & 299.8 & 251.8 & 220.8 & 189.8 & 173.8 \\
\hline MBC-3SB & 366.8 & NA & NA & NA & NA & 222 & 211 \\
\hline MBC-4SB & 380.8 & 344.8 & 301.8 & 269.8 & 238.8 & 206.8 & 187.8 \\
\hline MBC-5SB & 370.8 & 338.8 & 300.8 & 278.8 & 243.8 & 205.8 & 195.8 \\
\hline MBC-6SB & 326.8 & abs & 312.3 & 265.8 & 235.8 & 211.8 & 185.8 \\
\hline MBC-7SB & 328.8 & abs & 301.8 & 274.8 & 243.8 & 211.8 & 195.8 \\
\hline MBC-8SB & 380 & 353 & 308 & 273 & 230 & 201 & 190 \\
\hline MBC-8aSB & 371.8 & NA & NA & NA & $\mathrm{NA}$ & 195.8 & 187.8 \\
\hline MBC-9SB & 349.8 & 319.8 & 297.8 & 259.8 & 230.8 & 209.3 & 196.8 \\
\hline MBC-10SB & 359.8 & 328.8 & 289.8 & 261.8 & 235.8 & .199 .8 & 181.8 \\
\hline MBC-11SB & 360.8 & 330.8 & 305.8 & 271.8 & 245.8 & 213.8 & 193.8 \\
\hline MBC-12SB & 336.8 & 312.8 & 299.8 & 275.8 & 244.8 & 206.8 & 190.8 \\
\hline MBP-1SB & 317.8 & abs & 287.8 & 260.8 & 231.8 & 210.8 & 181.8 \\
\hline MBP-2SB & 336.7 & 296.7 & 282.7 & 261.7 & 230.7 & 200.7 & 182.7 \\
\hline MBP-4SB & 372.7 & 336.7 & 302.7 & 257.7 & 233.7 & 197.7 & 191.7 \\
\hline MBP-5SB & 360.5 & 325.5 & 300.5 & 276.5 & 236.5 & 196.5 & 183.5 \\
\hline MBP-6SB & 318.7 & NA & NA & NA & 232.7 & 205.7 & 190.7 \\
\hline MBP-7SB & 345 & NA & NA & NA & NA & 200 & 185 \\
\hline *MHT-1C & 362.7 & 326.7 & 302.7 & 275.7 & 253.2 & 220.7 & 197.7 \\
\hline MSB-2B & 352.3 & 318.3 & 305.3 & 267.3 & 242.3 & 216.3 & 196.3 \\
\hline MSB-4C & 353.1 & 324.1 & 302.1 & 279.1 & 248.1 & 220.1 & 201.1 \\
\hline MSB-5B & 343.1 & NA & NA & NA & NA & 216.1 & 194.1 \\
\hline MSB-6B & 341.8 & NA & NA & NA & $\mathrm{NA}$ & 206.8 & 190.8 \\
\hline MSB-7B & 342.1 & 320.1 & 299.1 & 274.1 & 242.1 & 204.1 & 188.1 \\
\hline *MSB-13CC & 344.8 & NA & NA & NA & NA & 217.8 & 194.8 \\
\hline MSB-23TA & 370.4 & 340.4 & 300.4 & 272.4 & 240.4 & 201.4 & 190.4 \\
\hline MSB-32B & 253.5 & abs & abs & abs & 227.5 & 203.5 & 195.5 \\
\hline *MSB-41TA & 321.7 & abs & 297.7 & 273.7 & 243.7 & 213.7 & 198.7 \\
\hline *MSB-43TA & 355.3 & 325.3 & 297.3 & 259.3 & 231.3 & 205.3 & 189.3 \\
\hline
\end{tabular}


Table 2.3. Unit Boundaries and Interval Tops (Continued)

\begin{tabular}{|c|c|c|c|c|c|c|c|}
\hline \multirow[b]{2}{*}{ Core $\mathbf{I D}$} & \multirow{2}{*}{$\begin{array}{c}\text { Surface } \\
\text { Elevation } \\
\text { (ft msl) }\end{array}$} & \multirow[b]{2}{*}{$\begin{array}{l}\text { "325" } \\
\text { Clay }\end{array}$} & \multirow[b]{2}{*}{$\begin{array}{c}\text { "300" } \\
\text { Clay }\end{array}$} & \multirow[b]{2}{*}{$\begin{array}{l}\text { "270" } \\
\text { Clay }\end{array}$} & \multirow[b]{2}{*}{$\begin{array}{l}\text { "230" } \\
\text { Clay }\end{array}$} & \multicolumn{2}{|c|}{ Steed Pond Aquifer } \\
\hline & & & & & & GCCZ & LLAZ \\
\hline $\mathrm{MSB}-48 \mathrm{C}$ & 360.2 & 339.2 & 313.2 & 265.2 & 245.2 & 206.2 & 200.2 \\
\hline *MSB-48TA & 359.8 & NA & NA & NA & NA & NA & NA \\
\hline *MSB-53B & 342.3 & NA & NA & NA & NA & NA & NA \\
\hline MSB-62B & 347 & 320 & 301 & 274 & 244 & 219 & 200 \\
\hline MSB-66TA & 380.5 & 346.5 & 294.5 & 269.5 & 235.5 & 211.5 & 197.5 \\
\hline MSB-67B & 362.7 & 342.7 & 302.7 & 267.7 & 233.7 & 200.7 & 184.7 \\
\hline MSB-71B & 342.9 & 309.9 & 293.9 & 262.9 & 230.9 & 212.9 & 197.9 \\
\hline MSB-72B & 326.7 & abs & 297.7 & 257.7 & 229.7 & 209.7 & 187.7 \\
\hline MSB-77TA & 354.9 & 316.9 & 310.9 & 256.9 & 227.9 & 201.9 & 188.9 \\
\hline MSB-81B & 265.1 & abs & abs & abs & 236.1 & 214.1 & 196.1 \\
\hline MSB-82C & 371.7 & 342.7 & 295.7 & 261.7 & 237.7 & 199.7 & 189.7 \\
\hline MSB-83C & 369.8 & 340.8 & 296.8 & 261.8 & 232.8 & 203.8 & 192.8 \\
\hline MSB-84C & 359.9 . & 337.9 & 290.9 & 252.9 & 227.9 & 210.9 & 195.9 \\
\hline *MSB-85C & 378.6 & 352.6 & 307.6 & 250.6 & 216.6 & 192.6 & 177.6 \\
\hline *MSB-87B & 334 & 308 & 299 & 262 & 236 & 205 & 190 \\
\hline MSB-88B & 235.8 & abs & abs & abs & abs & 199.8 & 189.8 \\
\hline MSB-89B & 337.3 & 307.3 & 296.3 & 271.3 & 231.3 & 204.3 & 185.3 \\
\hline MSS-1SB & 261.8 & abs & abs & 239.8 & 230.8 & $195.8^{\circ}$ & 183.8 \\
\hline MSS-2SB & 298.8 & abs & 278.8 & 248.8 & 220.8 & 203.8 & 181.8 \\
\hline MSS-3SB & 318.8 & 298.8 & 293.8 & 267.8 & 242.8 & 208.8 & 194.3 \\
\hline MSS-4SB & 337.8 & 318.8 & 305.8 & 265.8 & 247.8 & 222.8 & 194.8 \\
\hline MSS-5SB & 304.8 & abs & 272.8 & 260.8 & 233.8 & 199.8 & 188.3 \\
\hline MSS-6SB & 252.8 & abs & abs & abs & 228.8 & 207.8 & 176.8 \\
\hline MSS-7SB & 297.8 & abs & 277.8 & 261.8 & 229.8 & 205.8 & 194.8 \\
\hline MSS-8SB & $283.8^{\circ}$ & abs & abs & abs & 220.8 & 208.8 & 184.8 \\
\hline MSS-9SB & 316.8 & abs & 291.8 & 260.8 & 235.8 & 206.8 & 190.8 \\
\hline MSS-10SB & 305.8 & abs & 285.8 & 264.8 & 232.8 & 202.8 & 187.8 \\
\hline MW-1SB & 345.8 & 320.8 & 290.8 & 262.8 & 234.8 & 201.8 & 187.8 \\
\hline MW-2SB & 347.8 & 324.8 & 297.8 & 276.8 & 252.8 & 217.8 & 192.8 \\
\hline MW-3SB & 347.8 & 315.8 & 299.8 & 257.3 & 232.8 & 203.8 & 186.3 \\
\hline MW-4SB & 350.8 & 322.3 & 299.8 & 262.8 & 240.8 & 205.3 & 184.8 \\
\hline MW-5SB & 334.8 & 301.8 & 295.8 & 267.3 & 245.8 & 214.8 & 190.8 \\
\hline MW-6SB & 337.8 & 319.8 & 294.8 & 257.8 & 227.8 & 197.8 & 187.8 \\
\hline
\end{tabular}


Table 2.3. Unit Boundaries and Interval Tops (Continued)

\begin{tabular}{|c|c|c|c|c|c|c|c|}
\hline \multirow[b]{2}{*}{ Core ID } & \multirow{2}{*}{$\begin{array}{c}\text { Surface } \\
\text { Elevation } \\
\text { (ft msl) }\end{array}$} & \multirow[b]{2}{*}{$\begin{array}{l}\text { "325" } \\
\text { Clay }\end{array}$} & \multirow[b]{2}{*}{$\begin{array}{l}\text { "300" } \\
\text { Clay }\end{array}$} & \multirow[b]{2}{*}{$\begin{array}{l}\text { "270" } \\
\text { Clay }\end{array}$} & \multirow[b]{2}{*}{$\begin{array}{l}\text { "230" } \\
\text { Clay }\end{array}$} & \multicolumn{2}{|c|}{ Steed Pond Aquifer } \\
\hline & & & & & & GCCZ & LLAZ \\
\hline MW-7SB & 358 & $\mathrm{NA}$ & NA & $\mathrm{NA}$ & $\mathrm{NA}$ & 209.5 & 196 \\
\hline MW-8SB & 357.5 & NA & NA & NA & NA & 206.5 & 189.5 \\
\hline MW-9SB & 353.8 & NA & NA & NA & NA & 197.8 & 190.8 \\
\hline MW-10SB & 367.9 & NA & $\mathrm{NA}$ & NA & NA & 211.4 & 192.4 \\
\hline MW-11SB & 358.1 & 333.1 & 299.1 & 257.1 & 237.1 & 207.6 & 197.6 \\
\hline$M W-12 S B$ & 348.4 & NA & NA & NA & $\mathrm{NA}$ & 201.4 & 186.4 \\
\hline MW-13SB & 361.4 & NA & NA & NA & NA & 211.4 & 192.4 \\
\hline MW-14SB & 341.5 & 308.5 & 291.5 & 257.5 & 238.5 & 214.5 & 194.5 \\
\hline *P-30TA & 355.1 & 335.1 & 301.1 & 277.1 & 254.1 & 233.1 & 210.1 \\
\hline RWM-13B & 333.2 & 311.2 & 303.2 & 262.2 & 237.2 & 203.2 & 185.2 \\
\hline RWM-14B & 348.5 & 324.5 & 308.5 & 263.5 & 232.5 & 203.5 & 185.5 \\
\hline *RWM-15B & 365.9 & 335.9 & 296.9 & 269.9 & 235.9 & 202.9 & 191.9 \\
\hline RWM-16 & 318.4 & abs & 296.4 & 265.4 & 230.4 & 211.4 & 197.4 \\
\hline SRW-3BB & 330.3 & 307.3 & 290.3 & 252.8 & 235.3 & 220.3 & 209.3 \\
\hline
\end{tabular}

LLAZ - "Lost Lake" aquifer zone

GCCZ - "green clay" confining zone

abs - horizon absent

NA - data not available

* - Picks used for gridding control only, core data not used. 
Table 2.4. Unit Thickness

\begin{tabular}{|c|c|c|c|c|c|c|c|}
\hline \multirow[b]{2}{*}{ Core ID } & \multirow{2}{*}{$\begin{array}{c}\text { Surface } \\
\text { Elevation } \\
\text { (ft msl) }\end{array}$} & \multirow[b]{2}{*}{$\begin{array}{c}\text { "325" } \\
\text { Clay (ft) }\end{array}$} & \multirow[b]{2}{*}{$\begin{array}{c}\text { "300" } \\
\text { Clay (ft) }\end{array}$} & \multirow[b]{2}{*}{$\begin{array}{c}\text { "270" } \\
\text { Clay (ft) }\end{array}$} & \multirow[b]{2}{*}{$\begin{array}{c}\text { Clay } \\
(\mathrm{ft})\end{array}$} & \multicolumn{2}{|c|}{ Steed Pond Aquifer } \\
\hline & & & & & & $\operatorname{GCCZ}(\mathrm{ft})$ & LLAZ (ft) \\
\hline AMB-13A & 362.9 & 20 & 32 & 29 & 30 & 32 & \\
\hline ASB-2CR & 353.1 & 28 & 42 & 23 & 35 & 19 & \\
\hline ASB-6AA & 351.8 & 27 & 30 & 33 & 33.5 & 13 & \\
\hline GCB-1 & 335.8 & 18 & 25 & 38 & 29 & 24 & \\
\hline GCB-2 & 221 & & & & & & \\
\hline GCB-3 & 255.7 & & & & 16 & 13 & \\
\hline MBC-1SB & 371.8 & 61 & 40 & 30 & 25 & 12 & \\
\hline $\mathrm{MBC}-2 \mathrm{SB}$ & 379.8 & 55 & 48 & 31 & 31 & 16 & \\
\hline MBC-3SB & 366.8 & & & & & 11 & \\
\hline MBC-4SB & 380.8 & 43 & 32 & 31 & 32 & 19 & \\
\hline MBC-5SB & 370.8 & 38 & 22 & 35 & 38 & 10 & \\
\hline MBC-6SB & 326.8 & & 46.5 & 30 & 24 & 26 & \\
\hline MBC-7SB & 328.8 & & 27 & 31 & 32 & 16 & \\
\hline $\mathrm{MBC}-8 \mathrm{SB}$ & 380 & 45 & 35 & 43 & 29 & 11 & \\
\hline $\mathrm{MBC}-8 \mathrm{aSB}$ & 371.8 & & & & & 8 & \\
\hline MBC-9SB & $\cdot 349.8$ & 22 & 38 & 29 & 21.5 & 12.5 & \\
\hline MBC-10SB & 359.8 & 39 & 28 & 26 & 36 & 18 & \\
\hline MBC-11SB & 360.8 & 25 & 34 & 26 & 32 & 20 & \\
\hline $\mathrm{MBC}-12 \mathrm{SB}$ & 336.8 & 13 & 24 & 31 & 38 & 16 & \\
\hline MBP-1SB & 317.8 & & 27 & 29 & 21 & 29 & \\
\hline MBP-2SB & 336.7 & 14 & 21 & 31 & 30 & 18 & \\
\hline $\mathrm{MBP}-4 \mathrm{SB}$ & 372.7 & 34 & 45 & 24 & 36 & 6 & \\
\hline MBP-5SB & 360.5 & 25 & 24 & 40 & 40 & 13 & \\
\hline MBP-6SB & 318.7 & & & & 27 & 15 & \\
\hline MBP-7SB & 345 & & & & & 15 & \\
\hline${ }^{*} \mathrm{MHT}-1 \mathrm{C}$ & 362.7 & 24 & 27 & 22.5 & 32.5 & 23 & \\
\hline MSB-2B & 352.3 & 13 & 38 & 25 & 26 & 20 & \\
\hline MSB-4C & 353.1 & 22 & 23 & 31 & 28 & 19 & \\
\hline MSB-5B & 343.1 & & & & & 22 & \\
\hline MSB-6B & 341.8 & & & & & 16 & \\
\hline MSB-7B & 342.1 & 21 & 25 & 32 & 38 & 16 & \\
\hline *MSB-13CC & 344.8 & 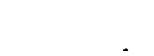 & & & & 23 & \\
\hline MSB-23TA & 370.4 & 40 & 28 & 32 & 39 & 11 & \\
\hline MSB-32B & 253.5 & & & & 24 & 8 & \\
\hline *MSB-41TA & 321.7 & & 24 & 30 & 30 & 15 & \\
\hline *MSB-43TA & 355.3 & 28 & 38 & 28 & 26 & 16 & \\
\hline
\end{tabular}


Table 2.4. Unit Thickness (Continued)

\begin{tabular}{|c|c|c|c|c|c|c|}
\hline \multirow[b]{2}{*}{ Corè ID } & \multirow{2}{*}{$\begin{array}{l}\text { Surface } \\
\text { Elevation } \\
\text { (ft msl) }\end{array}$} & \multirow[b]{2}{*}{$\begin{array}{c}\text { "325" } \\
\text { Clay (ft) }\end{array}$} & \multirow[b]{2}{*}{$\begin{array}{c}\text { "300" } \\
\text { Clay (ft) }\end{array}$} & \multirow[b]{2}{*}{$\begin{array}{c}\text { "270" } \\
\text { Clay (ft) }\end{array}$} & \multirow[b]{2}{*}{$\begin{array}{c}\text { Clay } \\
\text { (ft) }\end{array}$} & \multirow{2}{*}{$\begin{array}{l}\text { Steed Pond Aquifer } \\
\text { GCCZ (ft) LLAZ (ft) }\end{array}$} \\
\hline & & & & & & \\
\hline MSB-48C & 360.2 & 26 & 48 & 20 & 39 & 6 \\
\hline *MSB-48TA & 359.8 & & & & & \\
\hline *MSB-53B & 342.3 & & & & & \\
\hline MSB-62B & 347 & 19 & 27 & 30 & 25 & 19 \\
\hline MSB-66TA & 380.5 & 52 & 25 & 34 & 24 & 14 \\
\hline MSB-67B & 362.7 & 40 & 35 & 34 & 33 & 16 \\
\hline MSB-71B & 342.9 & 16 & 31 & 32 & 18 & 15 \\
\hline MSB-72B & 326.7 & & 40 & 28 & 20 & 22 \\
\hline MSB-77TA & 354.9 & 6 & 54 & 29 & 26 & 13 \\
\hline MSB-81B & 265.1 & & & & 22 & 18 \\
\hline MSB-82C & 371.7 & 47 & 34 & 24 & 38 & 10 \\
\hline MSB-83C & 369.8 & 44 & 35 & 29 & 29 & 11 \\
\hline MSB-84C & 359.9 & 47 & 38 & 25 & 17 & .15 \\
\hline *MSB-85C & 378.6 & 45 & 57 & 34 & 24 & 15 \\
\hline *MSB-87B & 334 & 9 & 37 & 26 & 31 & 15 \\
\hline MSB-88B & 235.8 & & & & & 10 \\
\hline MSB-89B & 337.3 & 11 & 25 & 40 & 27 & 19 \\
\hline MSS-1SB & 261.8 & & & 9 & 35 & 12 \\
\hline MSS-2SB & 298.8 & & 30 & 28 & 17 & 22 \\
\hline MSS-3SB & 318.8 & 5 & 26 & 25 & 34 & 14.5 \\
\hline MSS-4SB & 337.8 & 13 & 40 & 18 & 25 & 28 \\
\hline MSS-5SB & 304.8 & & 12 & 27 & 34 & 11.5 \\
\hline MSS-6SB & 252.8 & & & & 21 & 31 \\
\hline MSS-7SB & 297.8 & & 16 & 32 & 24 & 11 \\
\hline MSS-8SB & 283.8 & & & & 12 & 24 \\
\hline MSS-9SB & 316.8 & & 31 & 25 & 29 & 16 \\
\hline MSS-10SB & 305.8 & $\cdot$ & 21 & 32 & 30 & 15 \\
\hline MW-1SB & 345.8 & 30 & 28 & 28 & 33 & 14 \\
\hline$M W-2 S B$ & 347.8 & 27 & 21 & 24 & 35 & 25 \\
\hline MW-3SB & 347.8 & 16 & 42.5 & 24.5 & 29 & 17.5 \\
\hline $\mathrm{MW}-4 \mathrm{SB}$ & 350.8 & 22.5 & 37 & 22 & 35.5 & 20.5 \\
\hline MW-5SB & 334.8 & 6 & 28.5 & 21.5 & 31 & 24 \\
\hline MW-6SB & 337.8 & 25 & 37 & 30 & 30 & 10 \\
\hline
\end{tabular}


Table 2.4. Unit Thickness (Continued)

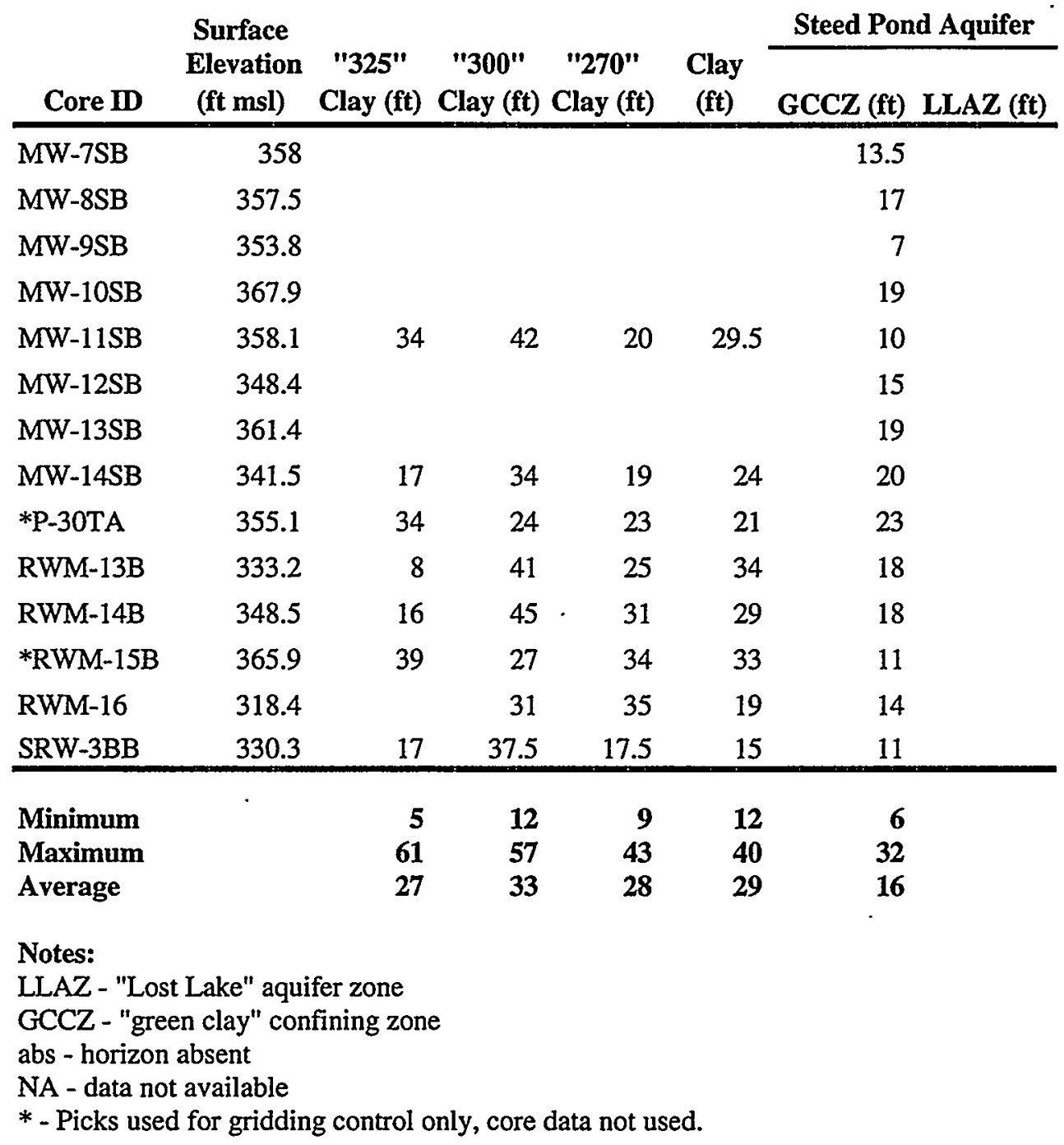




\subsection{RESULTS}

\subsection{Unit Geometry and Facies Analysis}

Figures 3-1 through 3-3 illustrate the resultant Earth Vision ${ }^{\circledR}$ model of the hydrostratigraphy and distribution of mud within each unit. The structure and mud-distribution maps are presented as Figures 3-4 through 3-26.

The block diagram in Figures 3-1 and 3-2 illustrates the approximate outcrop areas for each interval. Figure 3-1 indicates that the Tims Branch alluvial valley has incised the Steed Pond aquifer down to and slightly into the GCCZ. Figure 3-2 presents a cut-away view of the model, and illustrates the disconformable nature of the intervals boundaries. Figure 3-3 gives a three-dimensional visualization of the distribution of mud within the intervals as viewed from the same perspective as Figure 3-2. Figure 3-3 indicates that the Steed Pond aquifer primarily comprises layers of sand with less than 30 percent mud.

\subsection{1 "Green Clay" Confining Unit}

The top of the LLAZ defines the base of the GCCZ and is depicted in Figure 3-4. The measured elevation for the top of the GCCZ varies between 190 to $233 \mathrm{ft}$ bls (Figure 3-5, Table 2-3). The thickness of the GCCZ ranges between six and $32 \mathrm{ft}$. (Figure 3-6, Table 2-4). The average thickness of the GCCZ is approximately $17 \mathrm{ft}$. Figure 3-5 indicates that the top of the GCCZ is incised in the alluvial valley of Tims Branch. The elevation of the top of the GCCZ is much lower in the northern part of the study area.

The GCCZ is generally thicker in the southern half of the study area and where this interval has filled troughs in the top of the LLAZ. The isopach map indicates an especially thick section of this unit in the center of the study area (Figure 3-6).

The distribution of mud within the GCCZ is depicted in Figures 3-7 and 3-8. Figure 3-7 indicates that the mean mud content within the GCCZ varies from less than $10 \%$ to greater than $50 \%$ and is significantly higher in the areas where the unit is relatively thin. The GCCZ contains relatively small amounts of mud at the western end of the study area. The standard deviation of the mean mud percentages is generally larger in the areas with larger mud fractions. The parts of the GCCZ that lack mud tend to be thicker, and show smaller standard deviation values. This suggests that the GCCZ consists primarily of sand, with moderate amounts of interbedded clay. The maps of mud distribution indicate that the GCCZ is probably a competent confining zone beneath the area that is southeast of the M-Area Basin. 
The low mud percentages and small standard deviation values west of the M-Area Basin suggest that the GCCZ is relatively permeable in this area. These areas of lower mud content could serve as pathways for contaminant migration and a "pooling area" on top of the GCCZ. Recent investigation in that area indicates contamination on the GCCZ and down into the LLAZ (Jackson and others, 1996).

\subsection{2 "M-Area" Aquifer Zone/Vadose Zone}

\subsubsection{1 "230-Foot Clay"}

The "230-foot clay" is incised by the Tims Branch alluvial valley in the southeastern part of the study area (Figure 3-9). The measured elevation of the top varies between 217 to $254 \mathrm{ft}$ msl (Table 2-3). The average thickness of this unit is approximately 29 feet (Table 2-4). The isopach map indicates that this unit becomes relatively thin to the north and south and is thickest in the center of the study area between A Area and the M Area settling basin (Figure 3-10). The geometric mean and standard deviation of mud percentage are presented in Figures 3-11 and 3-12. The geometric mean of mud percentage for the "230-foot clay" varies from less than 10 to $45 \%$. Most of the study area is in the range of 10 to $30 \%$ mud. The standard deviation is largest in the thicker parts of this interval, and in areas with higher mud content (Figure 3-12). This indicates the "230-foot clay" is probably a relatively poor aquitard over large areas, but is relatively well-developed on a local basis.

\subsubsection{2 "270-Foot Clay"}

The "270-foot clay" is cut out in the valley of Tims Branch. (Figure 3-13). The measured elevation is between 240 to $282 \mathrm{ft} \mathrm{msl}$ (Table 2-3). The average thickness of this unit is approximately $27 \mathrm{ft}$ (Figure 3-14, Table 2-4). Core descriptions suggest this interval comprises several layers of clay and sand, which have abrupt facies changes and are very discontinuous across the area. The geometric mean and standard deviation of mud percentage are presented in Figures 3-15 and 3-16. The geometric mean of mud percentage for the "270foot clay" is consistent but relatively low. The areas with lower mean mud percentages do not appear to correspond with parts of the unit that are especially thick or thin (Figure 3-15). Higher standard deviation values for the mud percentage correspond with thicker parts of the unit and with some areas of high mud content (Figures 3-15 and 3-16), suggesting a highly variable lithology. This is consistent with the interbedded geometry observed in core samples from this interval. 


\subsubsection{3 "300-Foot Clay"}

The "300-foot clay" is cut out by Tims Branch (Figure 3-17). The measured elevation is between 273 to $321 \mathrm{ft}$ (Table 2-3). The average thickness of this unit is approximately $8 \mathrm{ft}$ (Figure 3-18, Table 2-4). Areas in which the top of the unit is relatively high correspond with areas where the unit is relatively thick and with low areas on the top of the "270-foot clay" (Figure 3-13). The geometric mean and standard deviation of mud percentage are presented in Figures 3-19 and 3-20. The geometric mean of mud percentage within the "300-foot clay" is relatively consistent across the study area and is generally less than 20 percent mud. The higher mud percentages are generally found in areas where the unit is relatively thick. Higher standard deviation values generally correspond with higher mud percentages within this unit. This indicates the " 300 -foot clay" is consistently sandy across the study area and probably does not present a significant barrier to groundwater movement.

\subsubsection{4 "325-Foot Clay"}

The "325-foot clay" is highly incised by the present drainage system (Figure 3-1). The measured elevation is between 297 to $355 \mathrm{ft}$ (Table 2-3). The altitude contour map indicates a local high centered under A Area (Figure 3-21). In the northern part of the area, the unit attains a thickness greater than $60 \mathrm{ft}$ (Figure 3-22, Table 2-4). The unit is thinner in the southern part of the study area (Figures 3-2 and 3-22). The geometric mean and standard deviation of mud percentage are presented in Figures 3-23 and 3-24. The geometric mean of mud percentage within the " 325 -foot clay" is consistently less than 30 percent mud across the study area (Figure 3-23). The larger standard deviation values generally correspond to the thicker parts of the unit (Figure 3-24).

\subsection{Comparison with Observed Extent of Groundwater Contamination}

One of the most important processes and parameters that influence this type of contaminant transport in groundwater is the distribution of hydraulic conductivity. The hydraulic conductivity couples with the regional groundwater sources and discharge areas to control groundwater migration patterns. An understanding of regional groundwater flow patterns, historical source information, and distribution of hydraulic conductivity allows investigators to effectively stage and deploy effective remediation programs.

Effective characterization of DNAPL contamination is often complicated by several factors. The migration of DNAPL through the subsurface is driven predominately by capillary and gravitational forces. The magnitude and direction of these forces are complex and are 
controlled by local variations in permeability of the soil. Current research indicates that DNAPL migration occurs at a sub-meter scale, much smaller than the resolution of conventional characterization methods.

Two forms of solvent contamination are present beneath $\mathrm{A} / \mathrm{M}$ Area. Dissolved groundwater plumes are widespread, extending from the central $\mathrm{A} / \mathrm{M}$ Area toward areas of surface discharge. The plumes cover a total area of approximately two square miles within various hydrostratigraphic units. DNAPL contamination is less widespread, but continuously contributes VOCs to the plumes. An effective remediation program will not only address the dissolved phase in the plumes, but will focus on locating, characterizing, and remediating the DNAPL from which the plumes emanate.

The migration of DNAPL down into the saturated zone and laterally along the strata serves as the primary source type associated with the Western Sector and Central Sector (M-Area Basin and A-014 Outfall). Characterization and remediation efforts in the Western Sector require identifying the location and thickness of DNAPL along these strata for the deployment of appropriate DNAPL removal/destruction technologies.

As DNAPL migrates away from the M Area Settling Basin and A-014 outfall, the GCCZ is believed to be the most significant factor controlling lateral migration of the contamination (Jackson and others, 1997). The current conceptual model describes DNAPL as migrating west from the M-Area Basin toward well clusters MSB-23 and MSB-76 (Looney and others, 1992). Data from several monitoring wells and depth-discrete samples along this route indicate a probable presence of DNAPL above and below the GCCZ. These data indicate that as the DNAPL has moved west, it has migrated vertically through the GCCZ into the LLAZ. Layers of low-permeability strata within the LLAZ appear to have inhibited further vertical migration.

The altitude contour map of the GCCZ presented in Figure 3-5 supports the concept of westward migration from the M-Area Basin. Even more dramatic is the distinct decrease in the mean mud fraction beneath the area west of the M-Area Basin (Figure 3-7). The facies change associated with the decrease in mud percentage indicates an overall increase in permeability of the sediment. This increase in permeability will allow DNAPL to migrate through the GCCZ as it moves west from the basin. Monitoring wells west of the M-Area Basin indicate elevated contaminant concentrations in the upper part of the LLAZ. This observation is consistent with the lithologic variations indicated by Figures 3-7 and 3-8. 
In $\mathrm{A} / \mathrm{M}$ Area, the presence of subsurface DNAPL has combined with the local hydrologic . conditions to create a large TCE plume south and west of the M-Area Basin and the A-014 Outfall in Southern Sector. This plume is migrating vertically through the GCCZ into the LLAZ where it spreads south and west toward Upper Three Runs Creek. The downward migration results from several factors that contribute to a strong downward gradient across the GCCZ. These factors include facies changes within the GCCZ, the location of groundwater divides, and the presence of groundwater discharge zones. The large difference in hydraulic conductivity between the "M Area" and "Lost Lake" aquifer zones is another major factor. Recent groundwater models have estimated hydraulic conductivity values (beneath Southern Sector) of between 5 and $10 \mathrm{ft} / \mathrm{d}$ for the MAAZ, and up to $20 \mathrm{ft} / \mathrm{d}$ for the LLAZ (Jackson, 1994; HydroGeoLogic, 1996). Once below the GCCZ, the proximity of groundwater discharge zones and the effects of the Crouch Branch confining unit result in the southward migration of the plume within the LLAZ. 


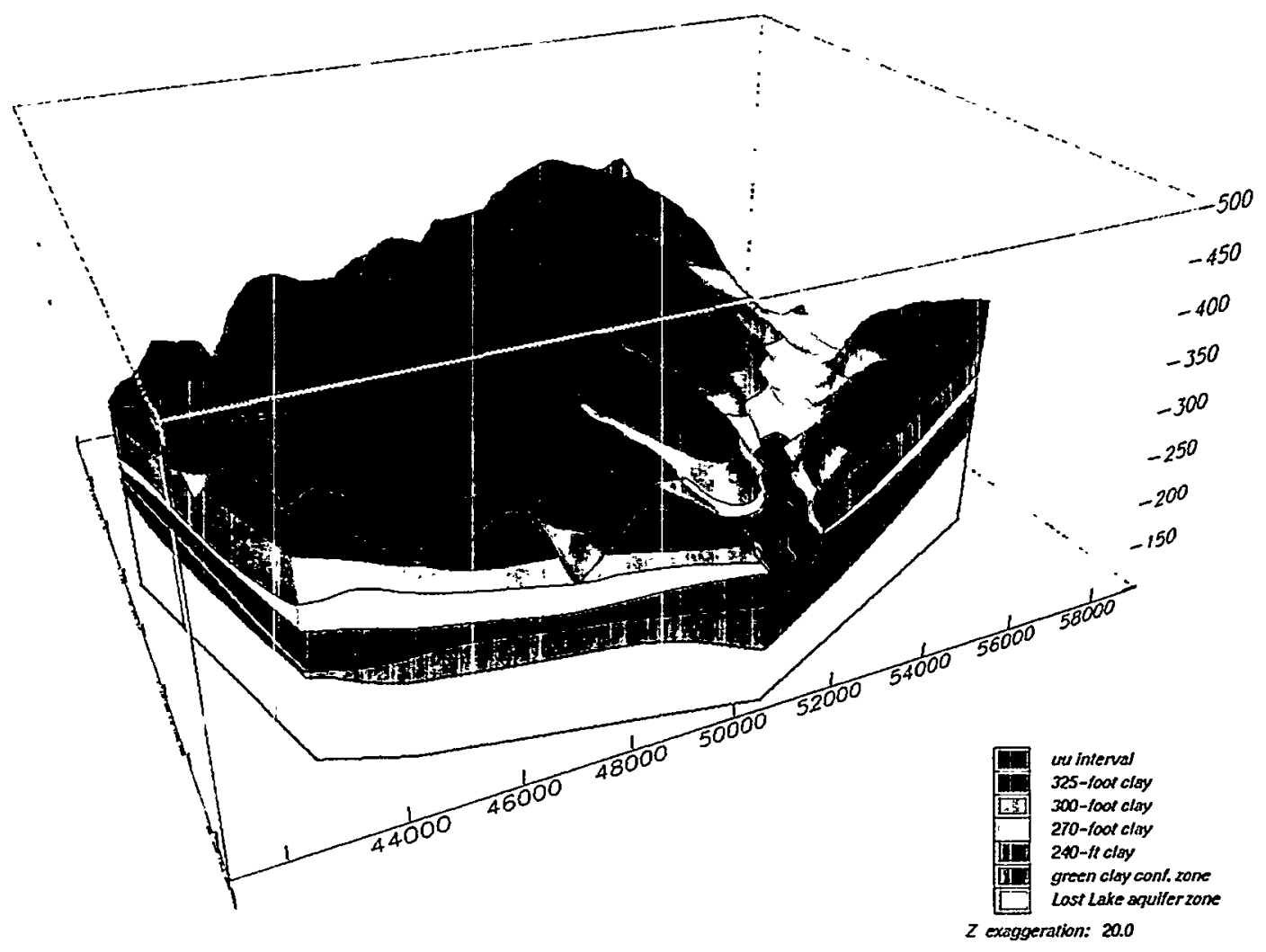

Figure 3-1. $\quad$ EarthVision ${ }^{\circledR}$ Structure Builder Model of the Study Area 


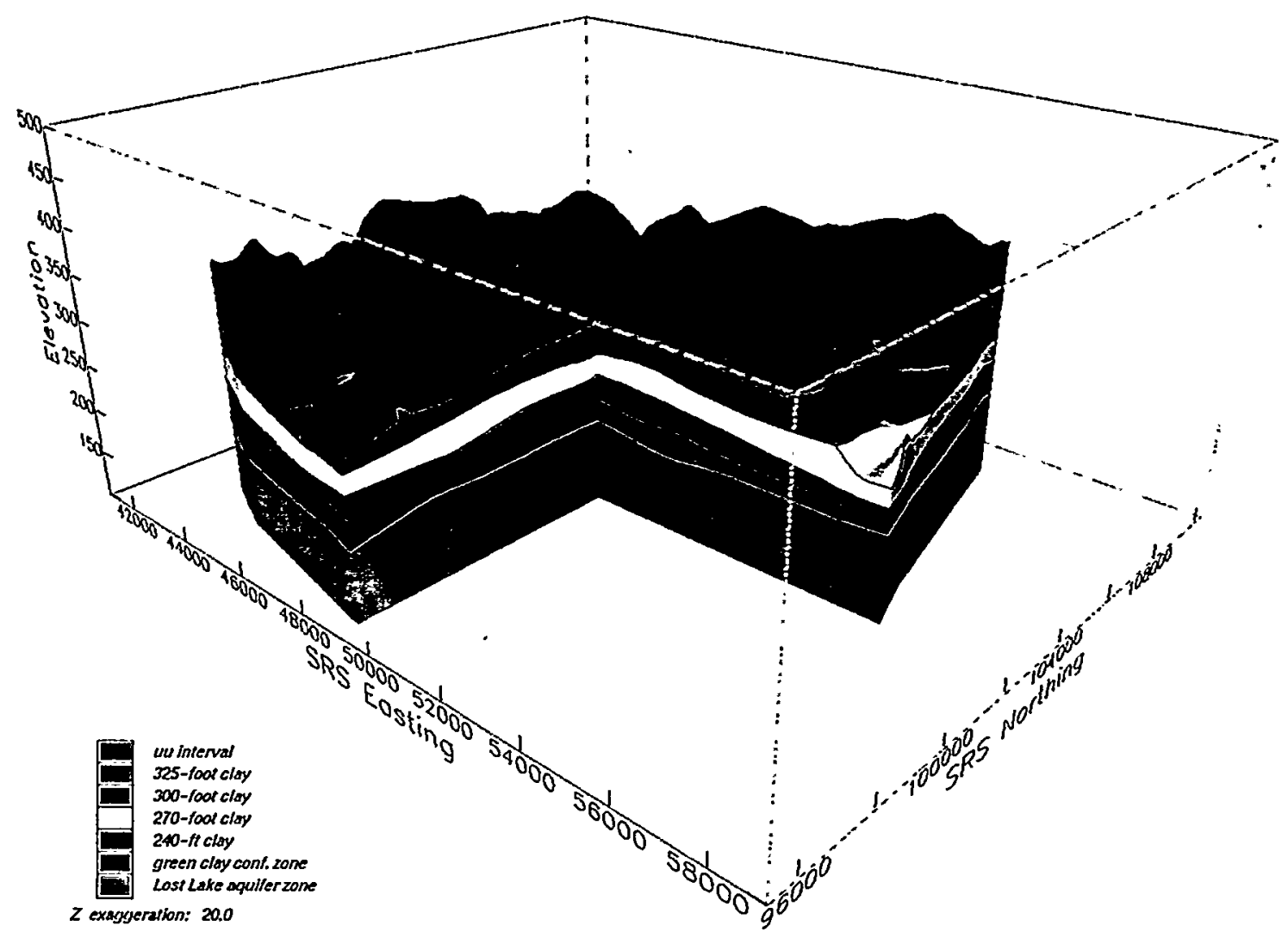

Figure 3-2. Chair-Cut through EarthVision ${ }^{\circledR}$ Model 


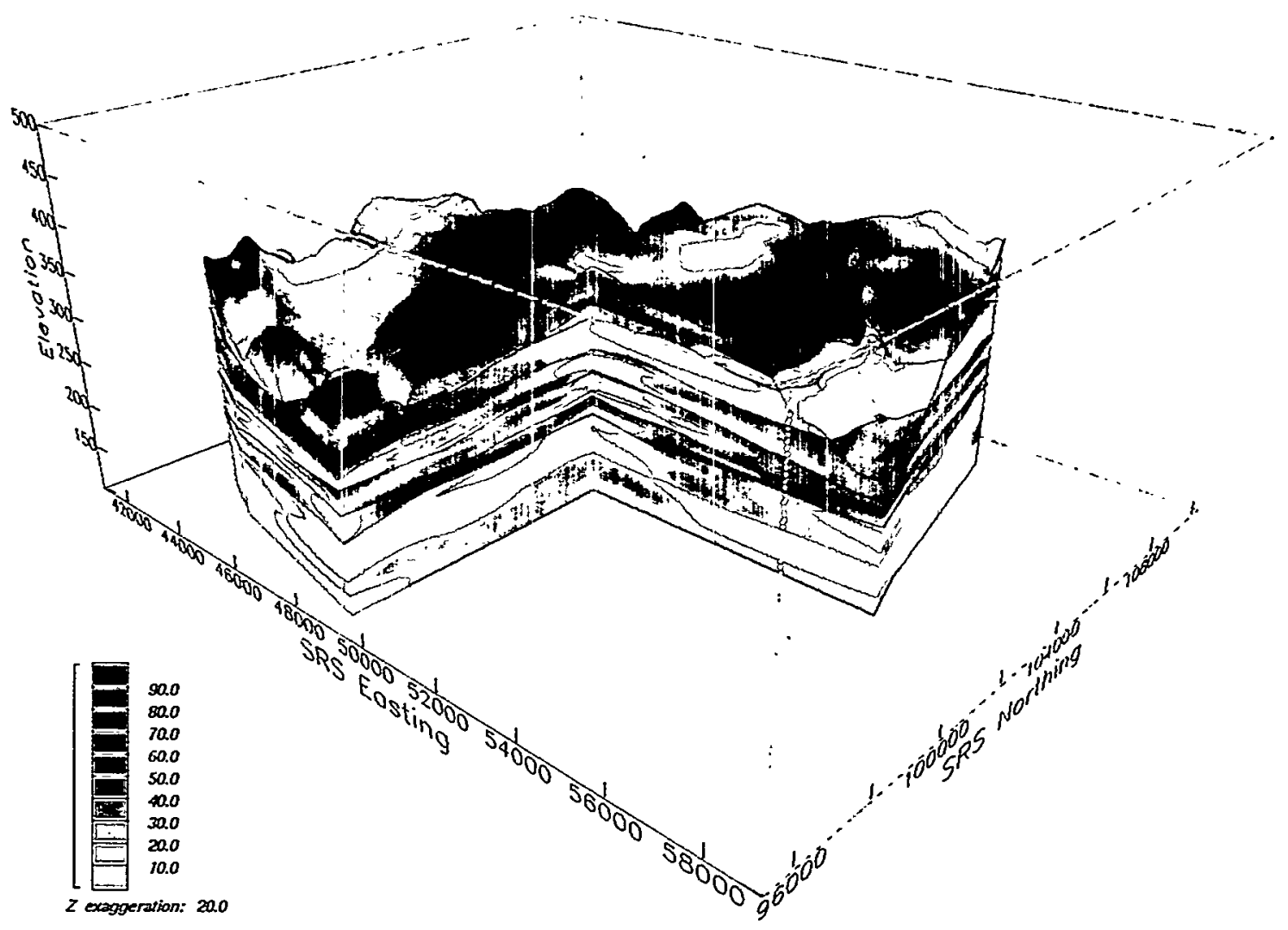

Figure 3-3. Three-Dimensional Visualization of Mud Fraction within Model Domain 
Top of the "Lost Lake" Aquifer
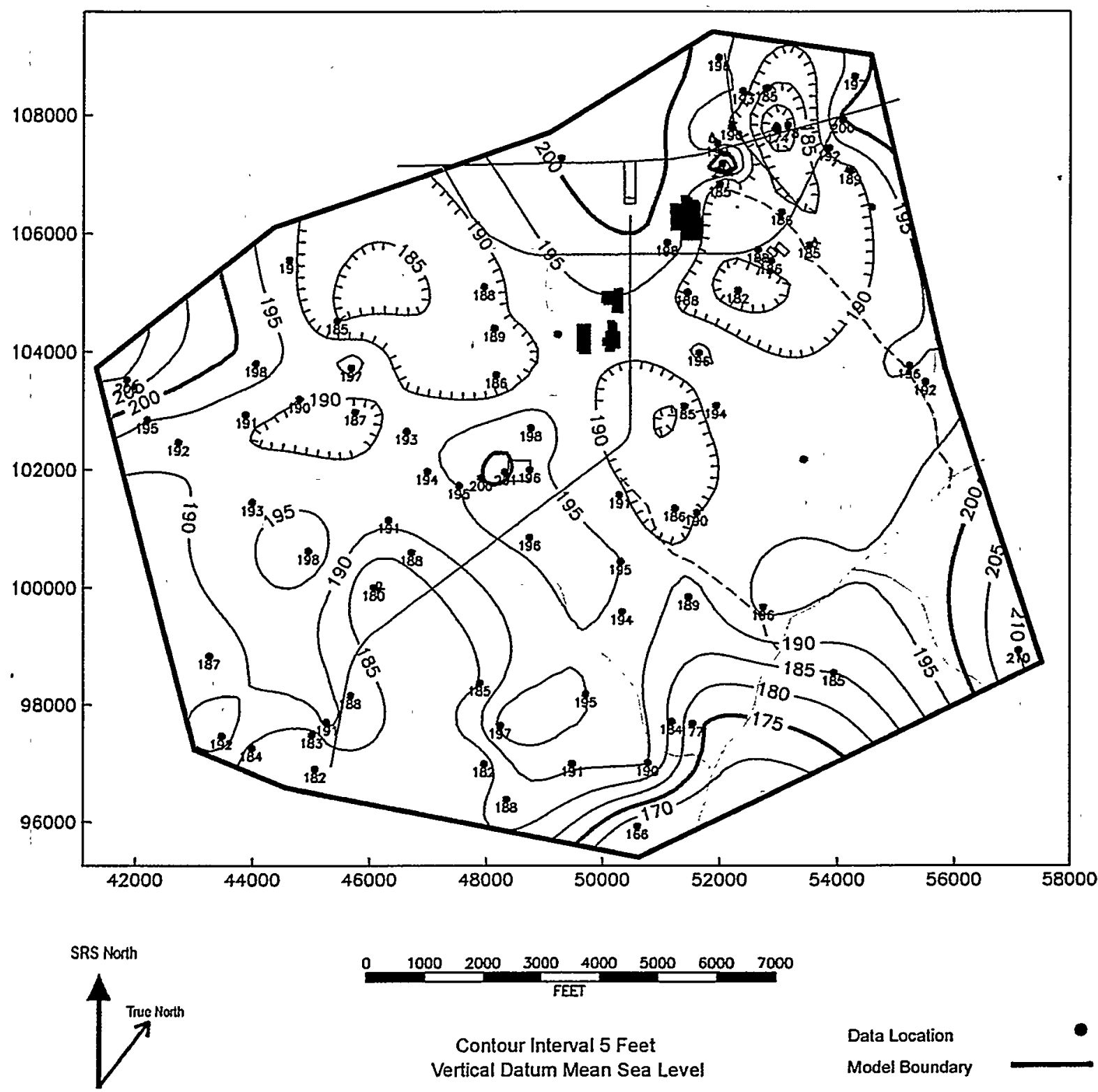

Contour Interval 5 Feet

Vertical Datum Mean Sea Level

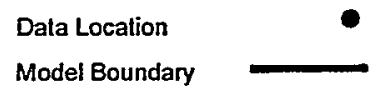

Figure 3-4. Altitude Contour Map of the Top of the "Lost Lake" Aquifer/Base of the "Green Clay" Confining Zone 


\section{Top of the "Green Clay" Confining Zone}
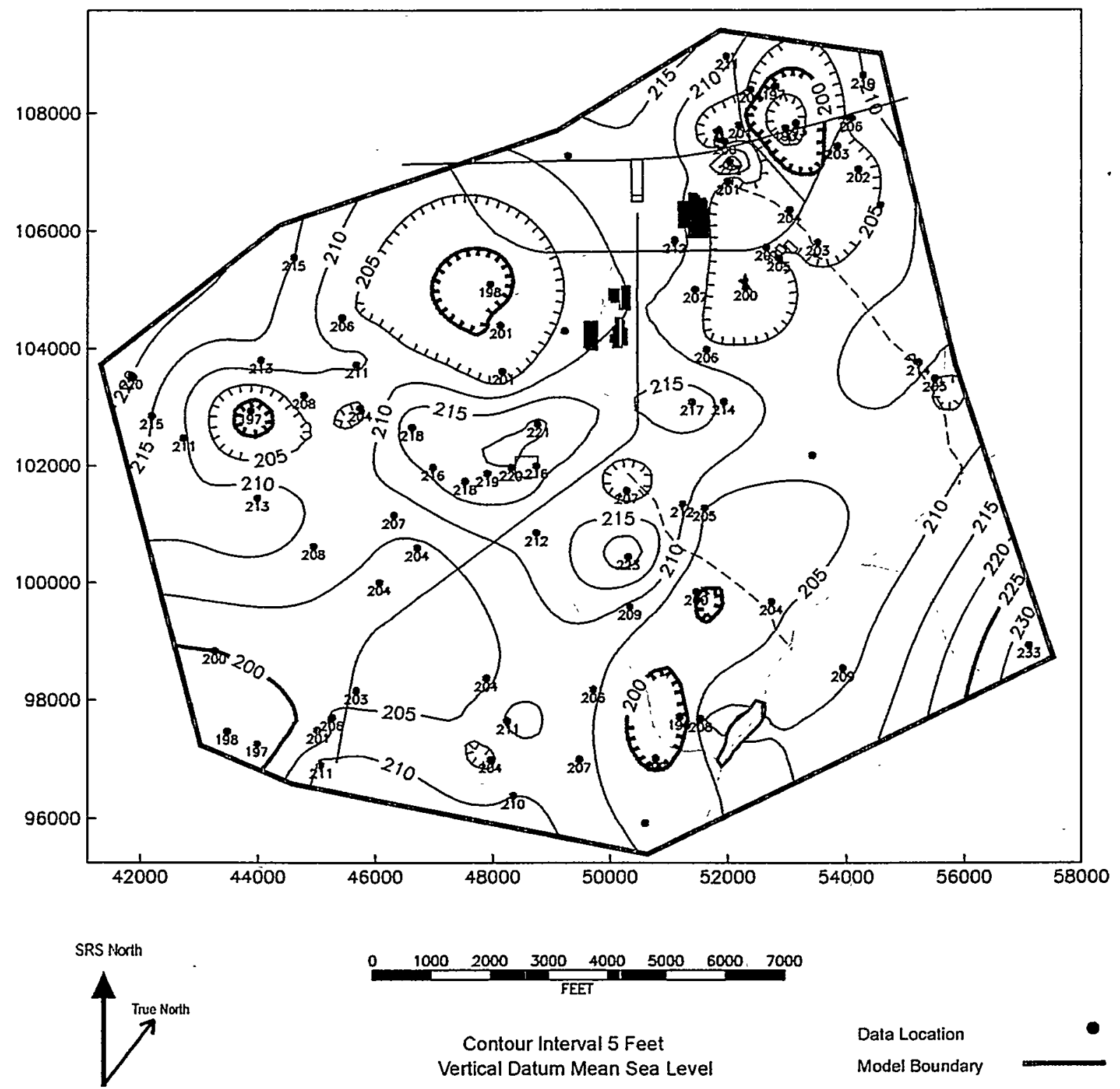

Contour Interval 5 Feet Vertical Datum Mean Sea Level

Dala Location

Model Boundary

Figure 3-5. Altitude Contour Map of the Top of the "Green Clay" Confining Zone/Base of the "M-Area" Aquifer Zone 


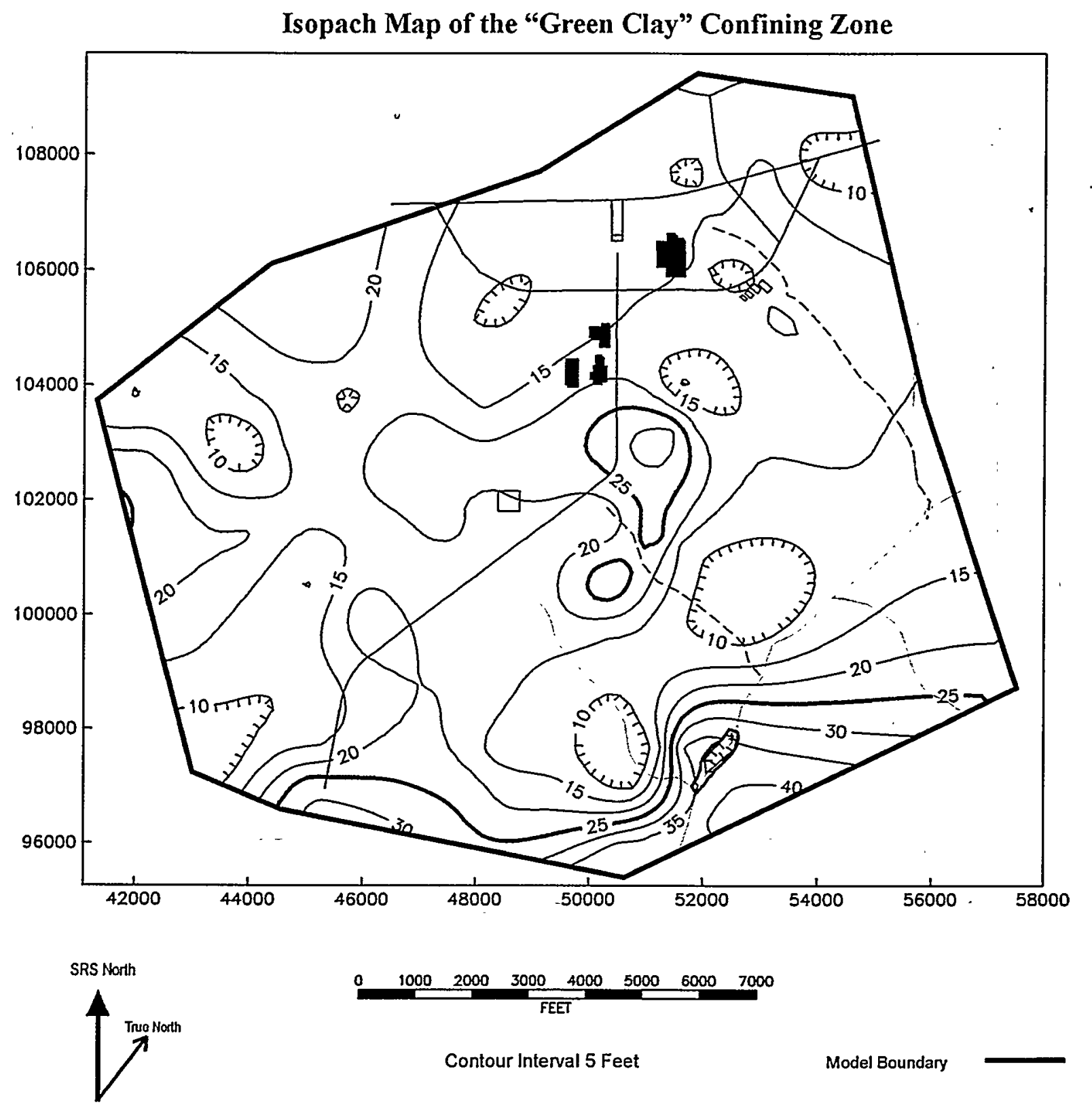

Figure 3-6. Isopach Map of the "Green Clay" Confining Zone 
Geometric Mean of Mud within the "Green Clay" Confining Zone

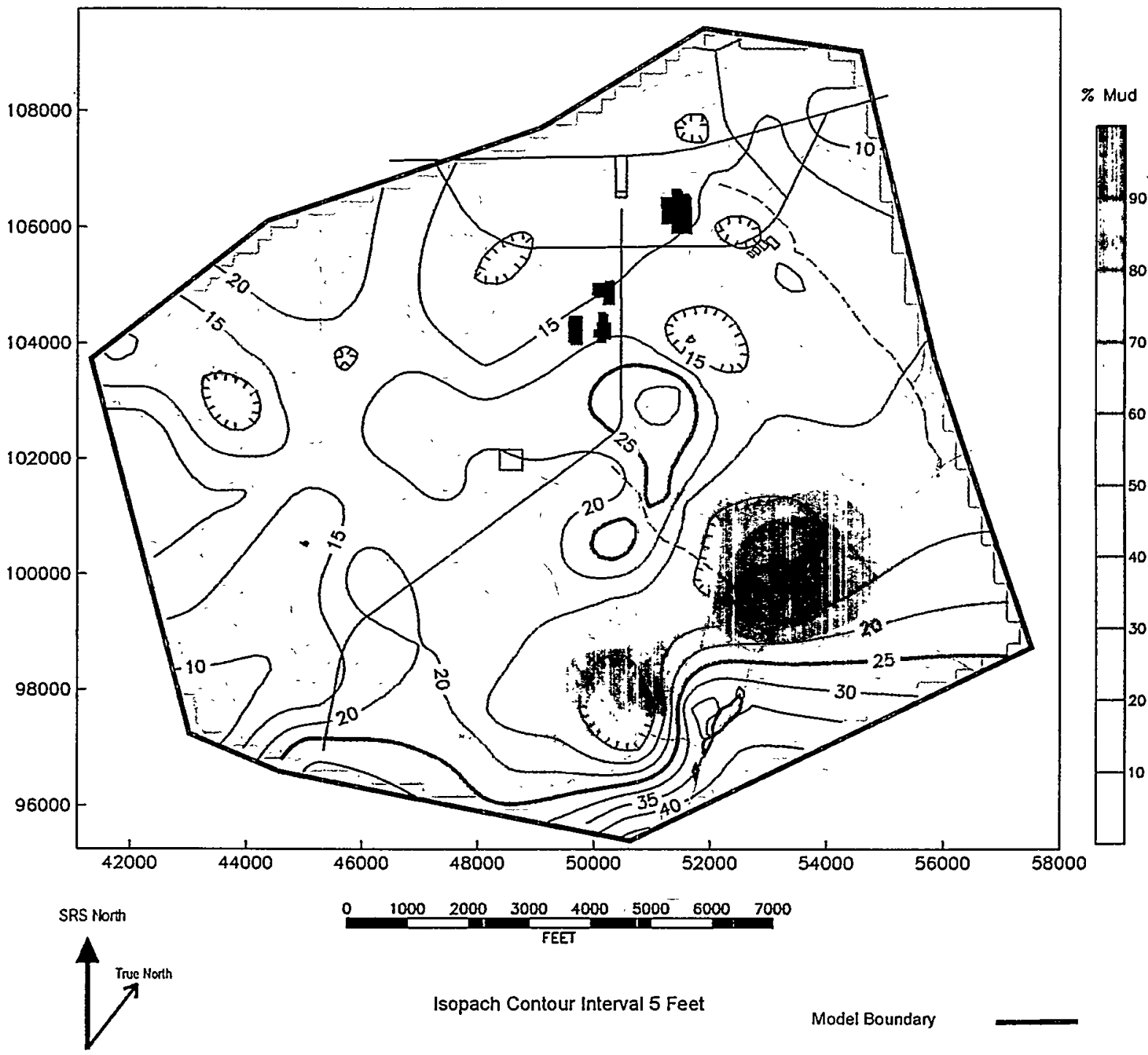

Figure 3-7. Geometric Mean of Mud Percentage within the "Green Clay" Confining Zone 
Standard Deviation of Mud within the "Green Clay" Confining Zone

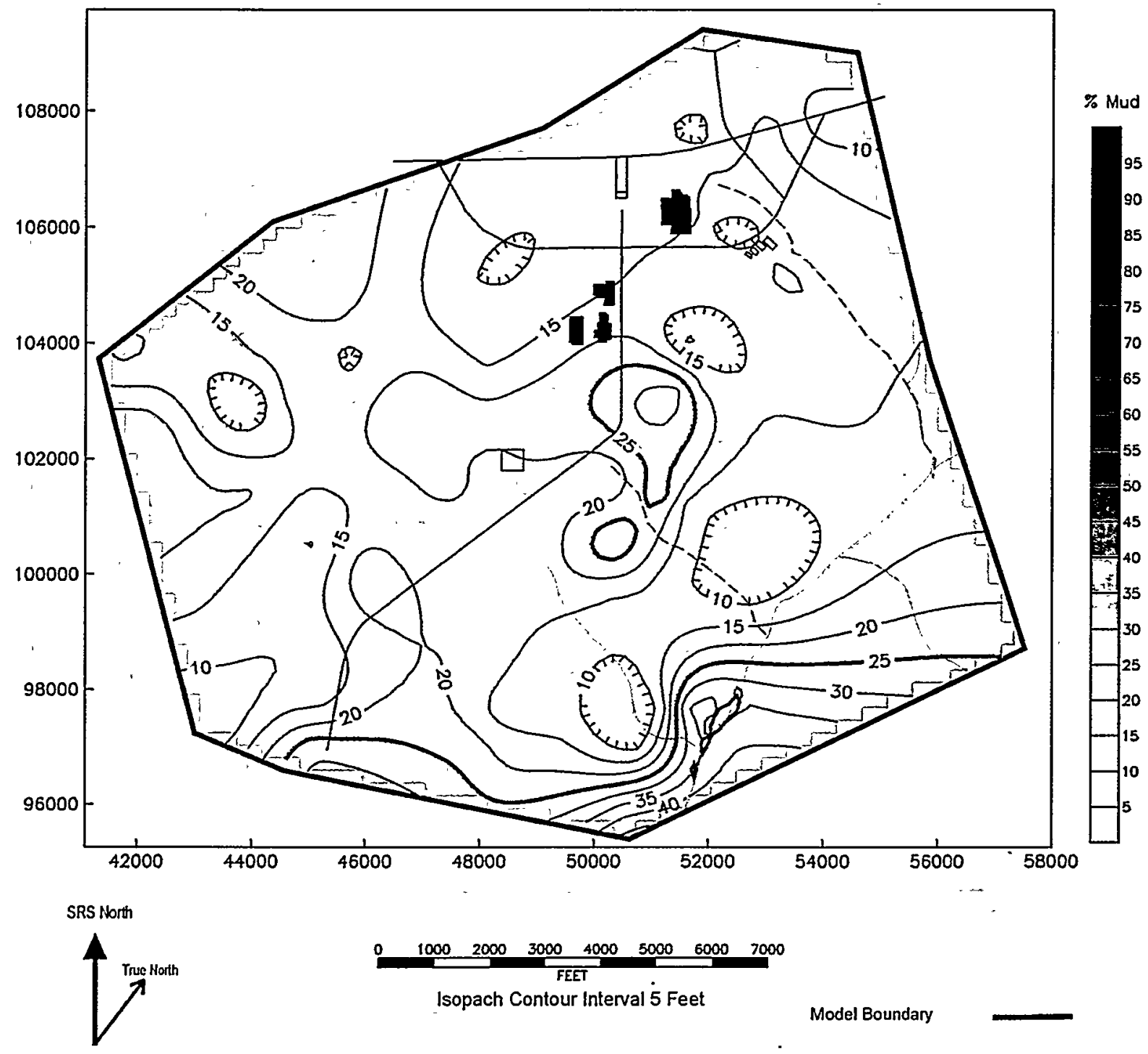

Figure 3-8. Standard Deviation of Mud Percentage within the "Green Clay" Confining Zone 


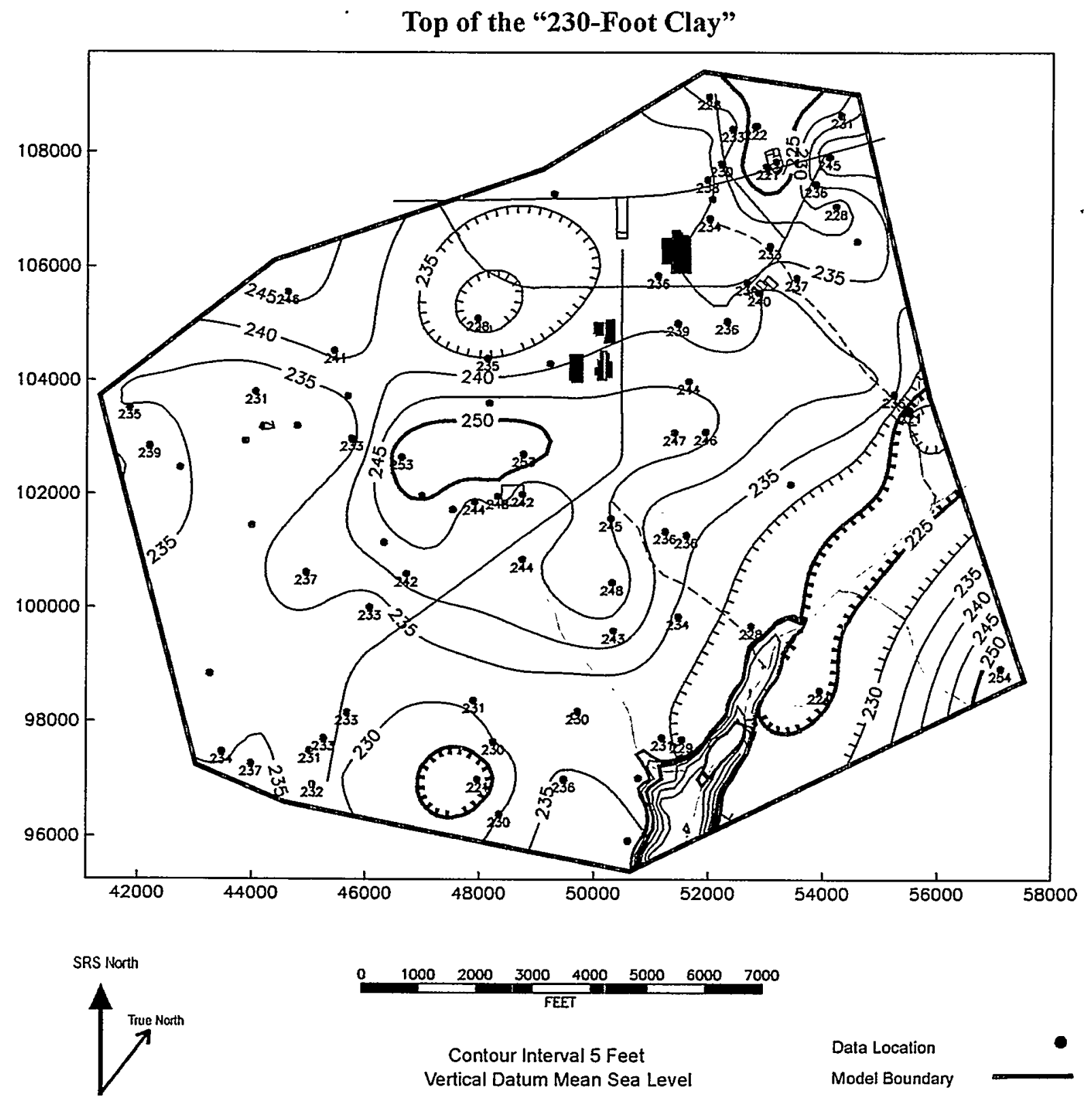

Figure 3-9. Altitude Contour Map of the Top of the "230-Foot Clay"/Base of the "270-Foot Clay" 

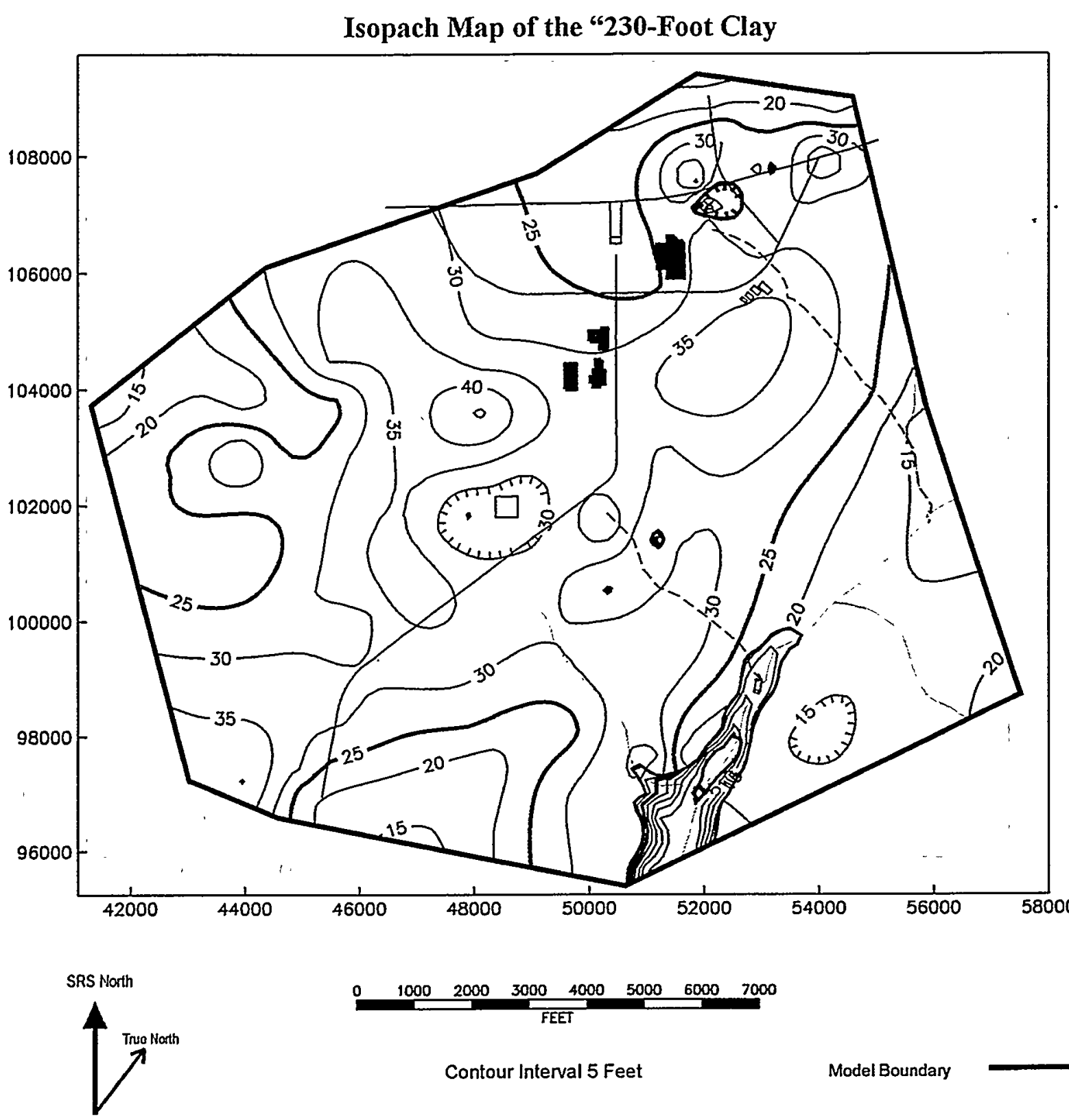

Contour Interval 5 Feet

Model Boundary

Figure 3-10. Isopach Map of the "230-Foot Clay" 


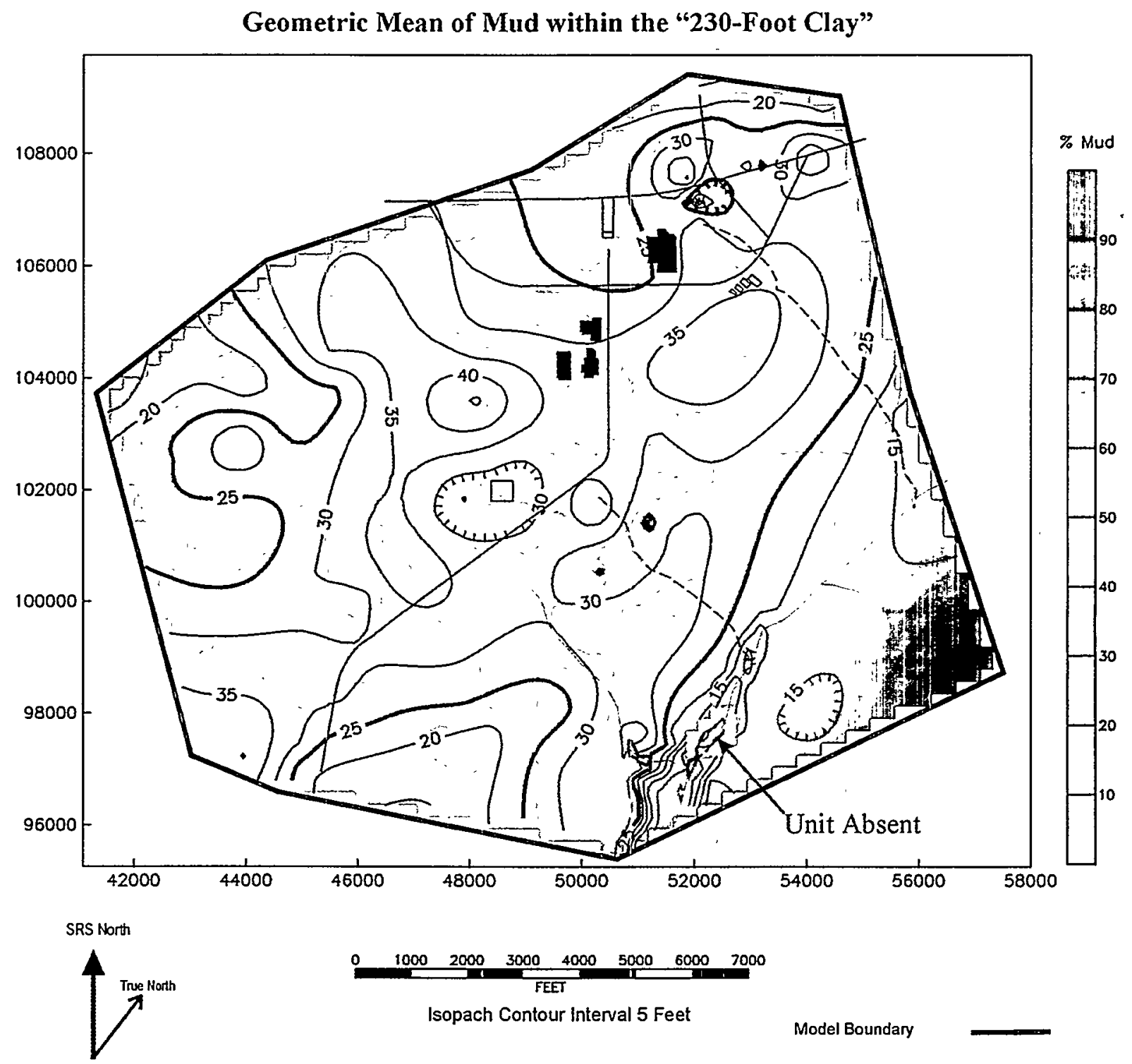

Figure 3-11. Geometric Mean of Mud Percentage within the "230-Foot Clay" 
Standard Deviation of Mud within the "230-Foot Clay"
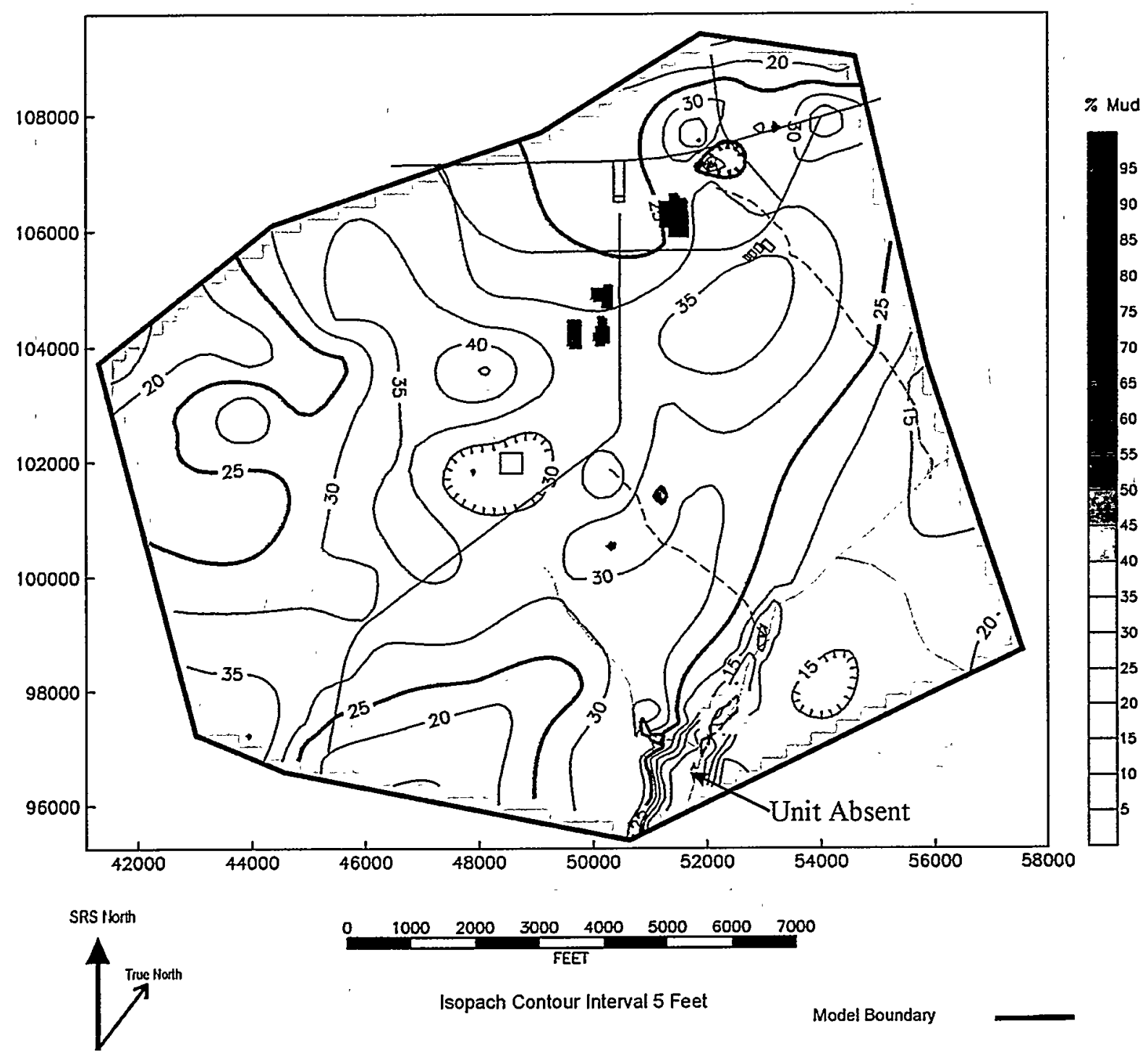

Isopach Contour Interval 5 Feet

Model Boundan

Figure 3-12. Standard Deviation of Mud Percentage within the "230-Foot Clay" 


\section{Top of the "270-Foot Clay"}
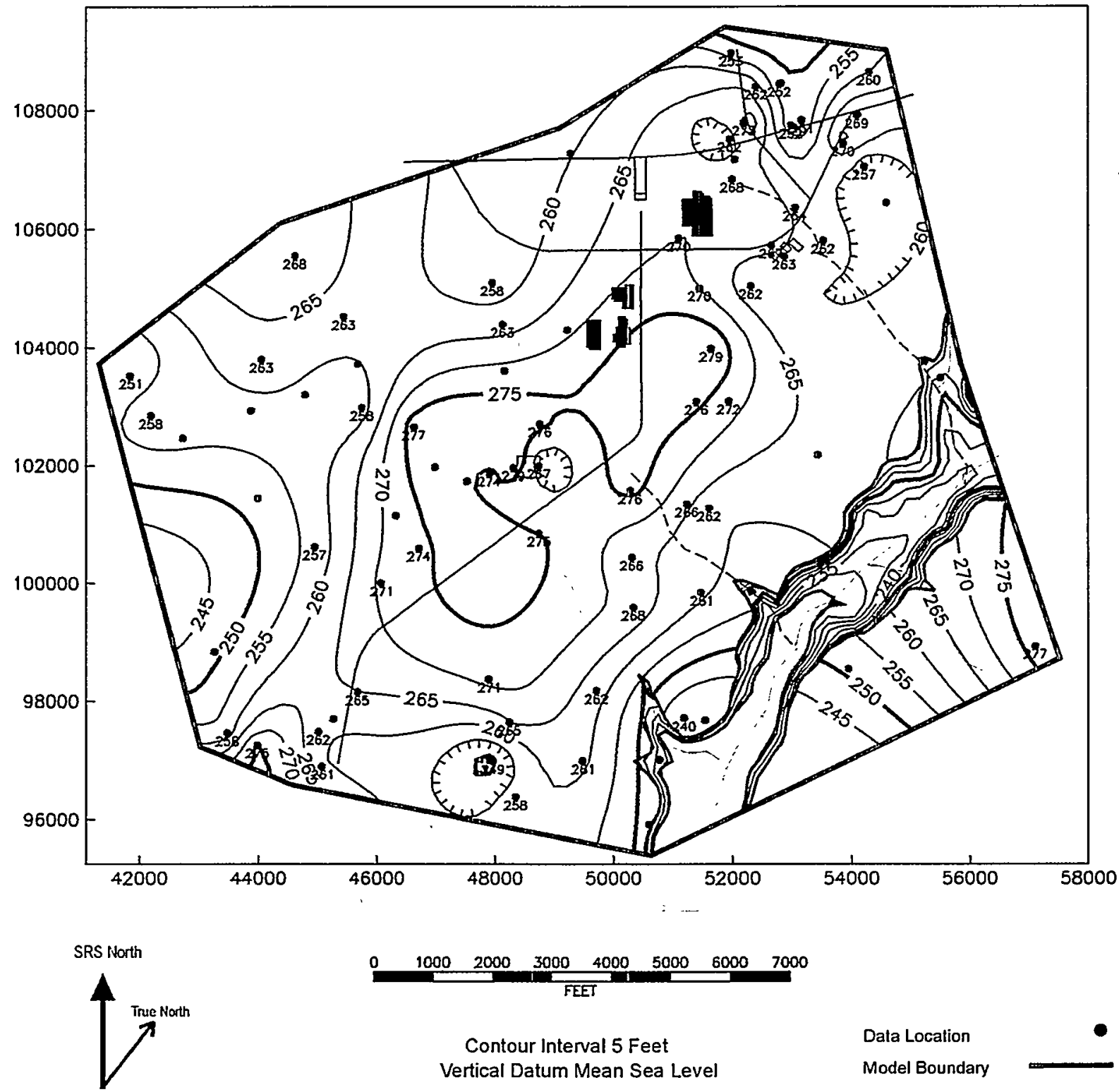

Contour Interval 5 Feet

Vertical Datum Mean Sea Level

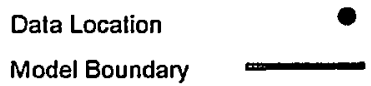

Figure 3-13. Altitude Contour Map of the Top of the "270-Foot Clay"/Base of the “300-Foot Clay" 
Isopach Map of the "270-Foot Clay"
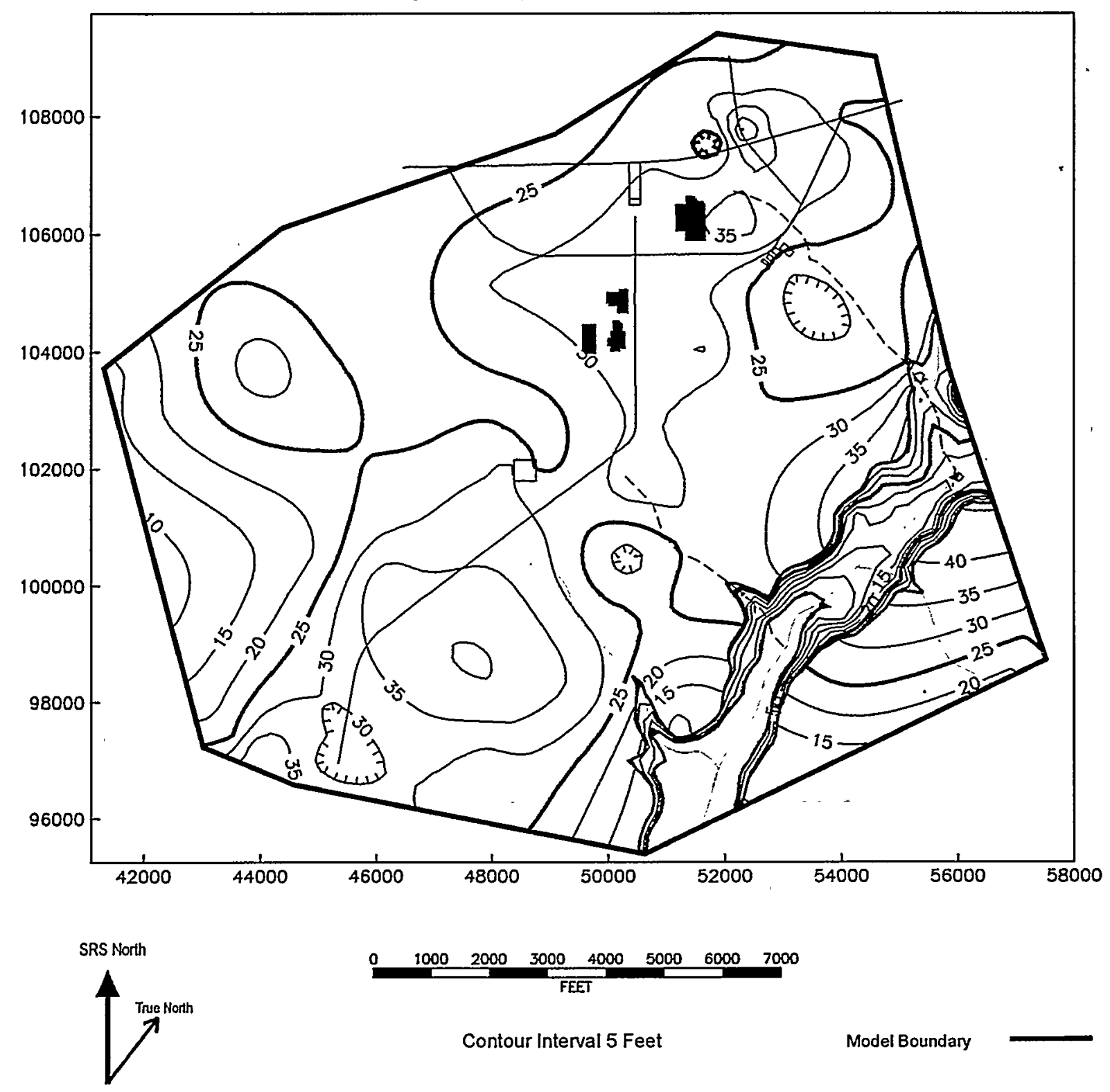

$\frac{1000 \quad 2000 \quad 3000 \quad 4000 \quad 5000 \quad 6000 \quad 7000}{\text { FEET }}$

Contour Interval 5 Feet

Model Boundary

Figure 3-14. Isopach Map of the Top of the "270-Foot Clay" 


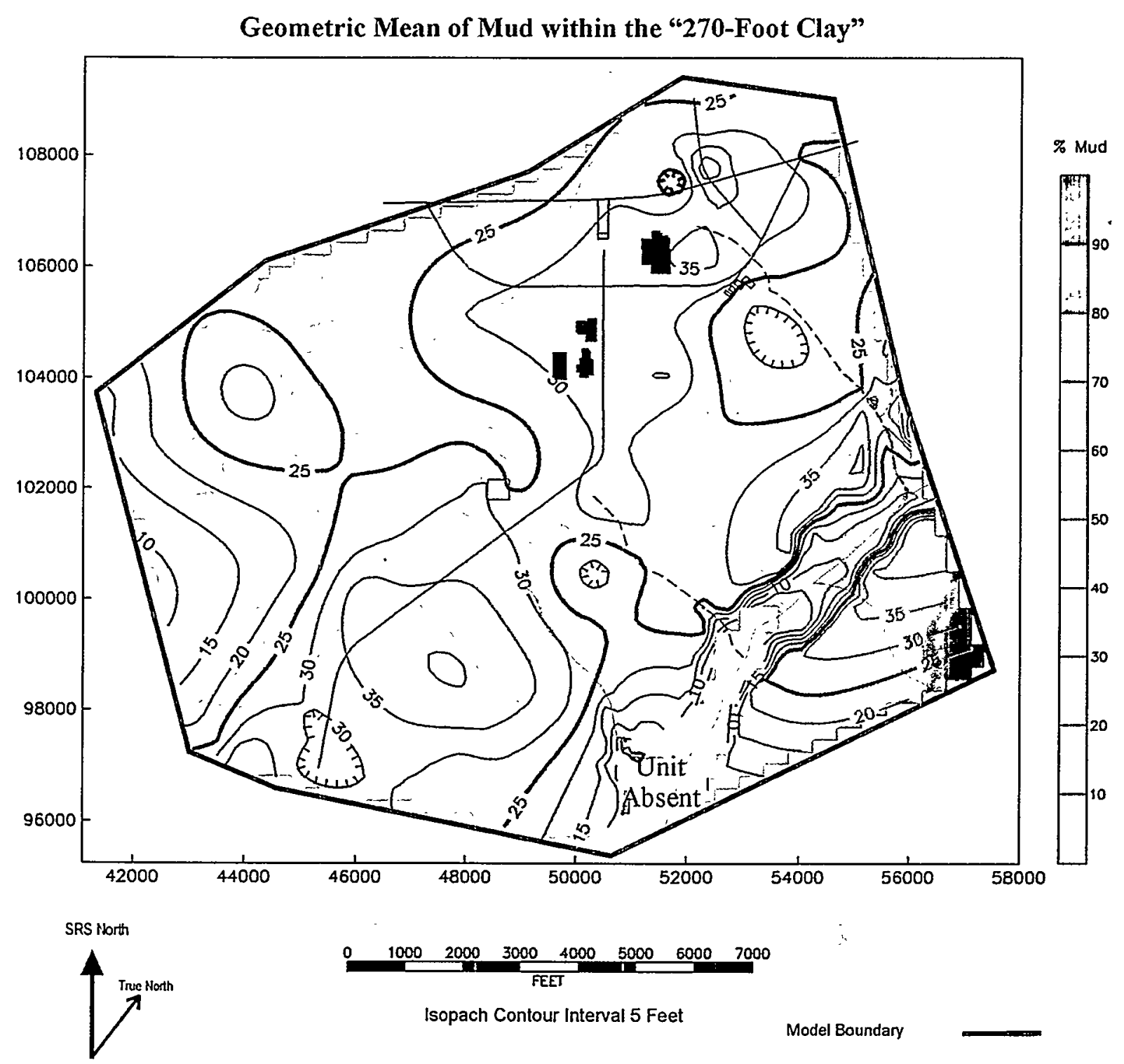

Figure 3-15. Geometric Mean of Mud Percentage within "270-Foot Clay" 


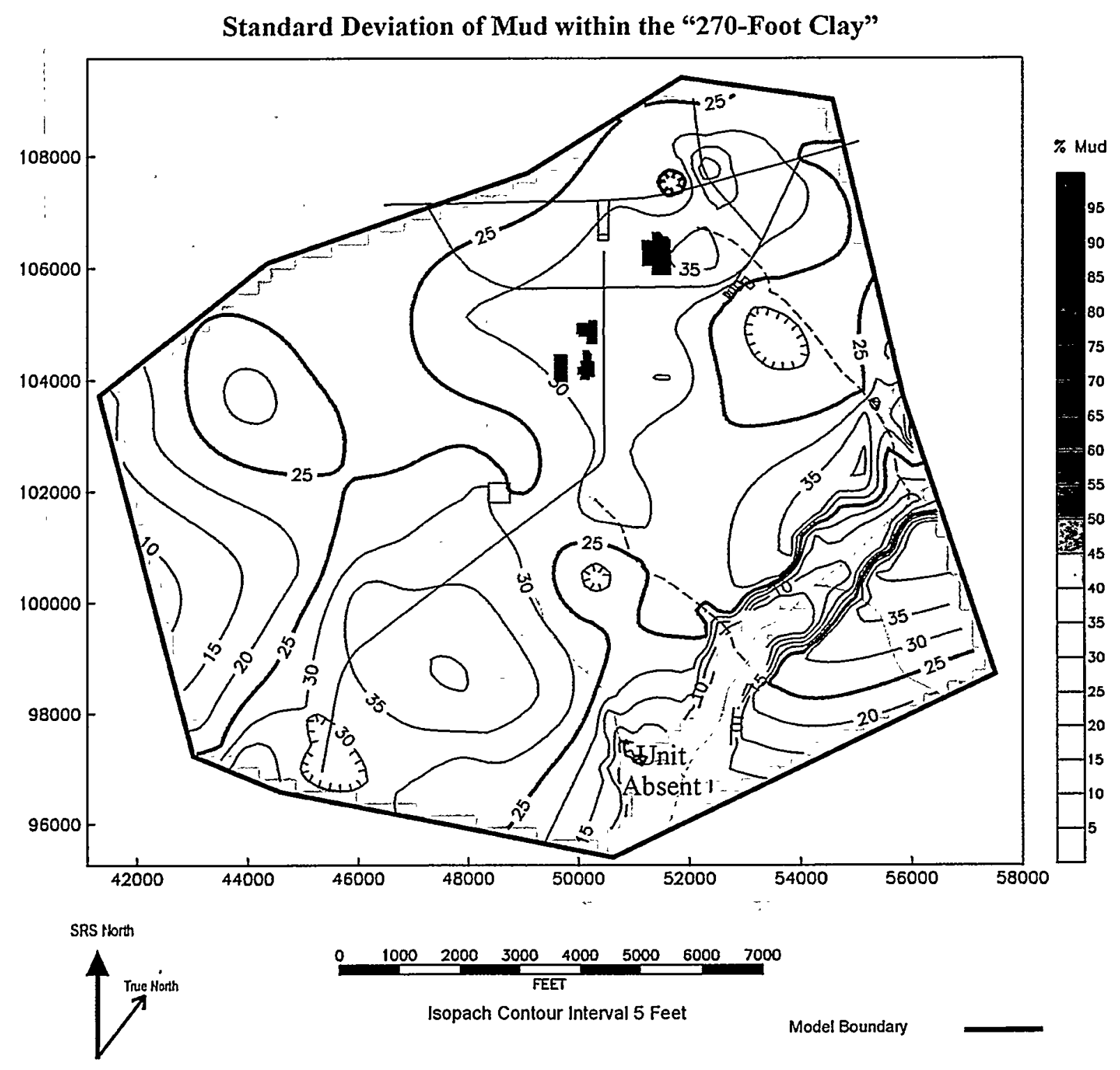

Figure 3-16. Standard Deviation of Mud Percentage within the "270-Foot Clay" 


\section{Top of the "300-Foot Clay"}

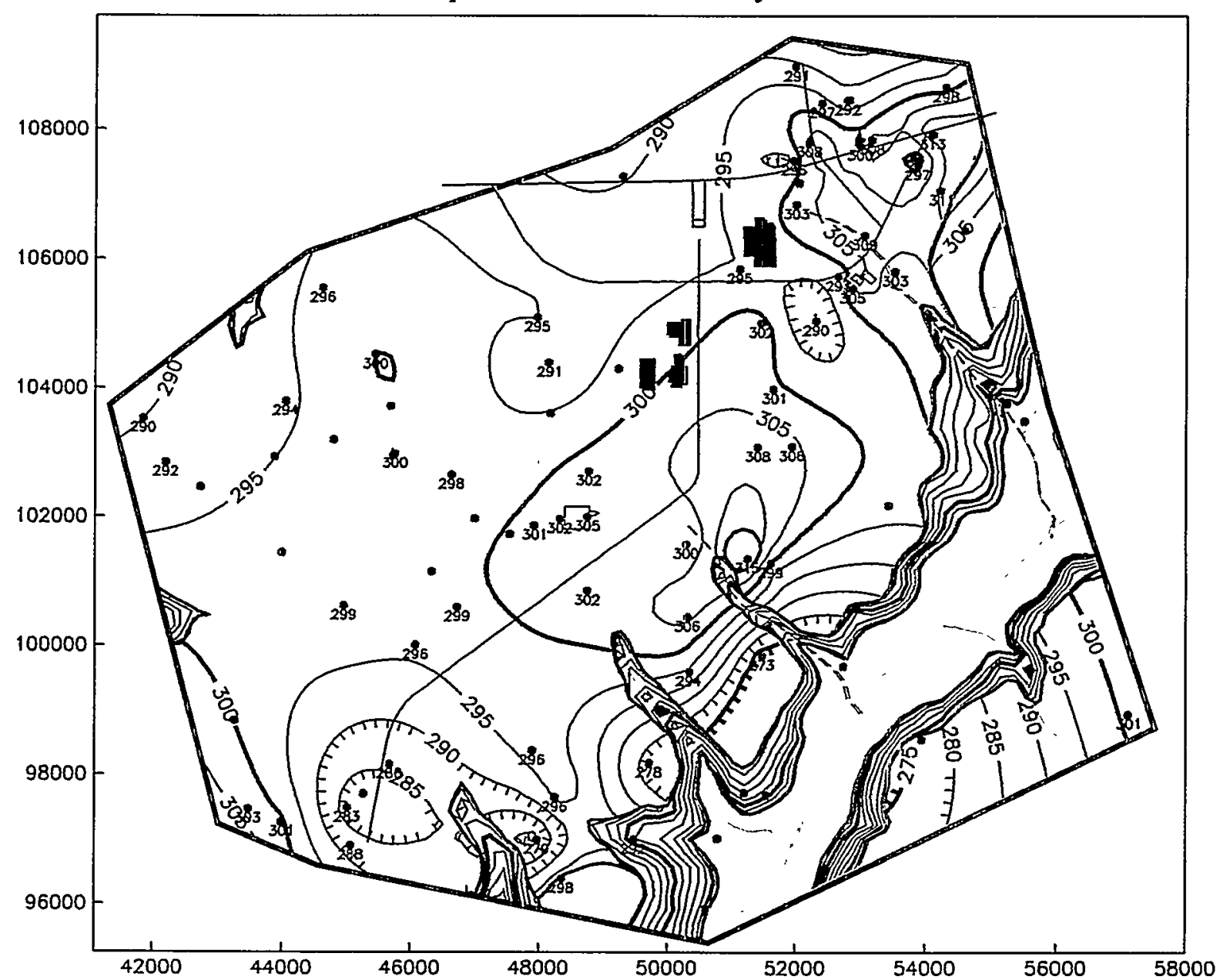

SRS North

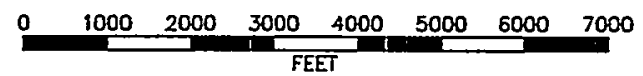

Contour Interval 5 Feet

Vertical Datum Mean Sea Level

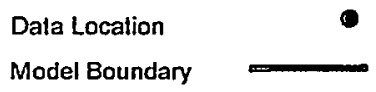

Figure 3-17. Altitude Contour Map of the Top of the "300-Foot Clay"/Base of the "325-Foot Clay" 


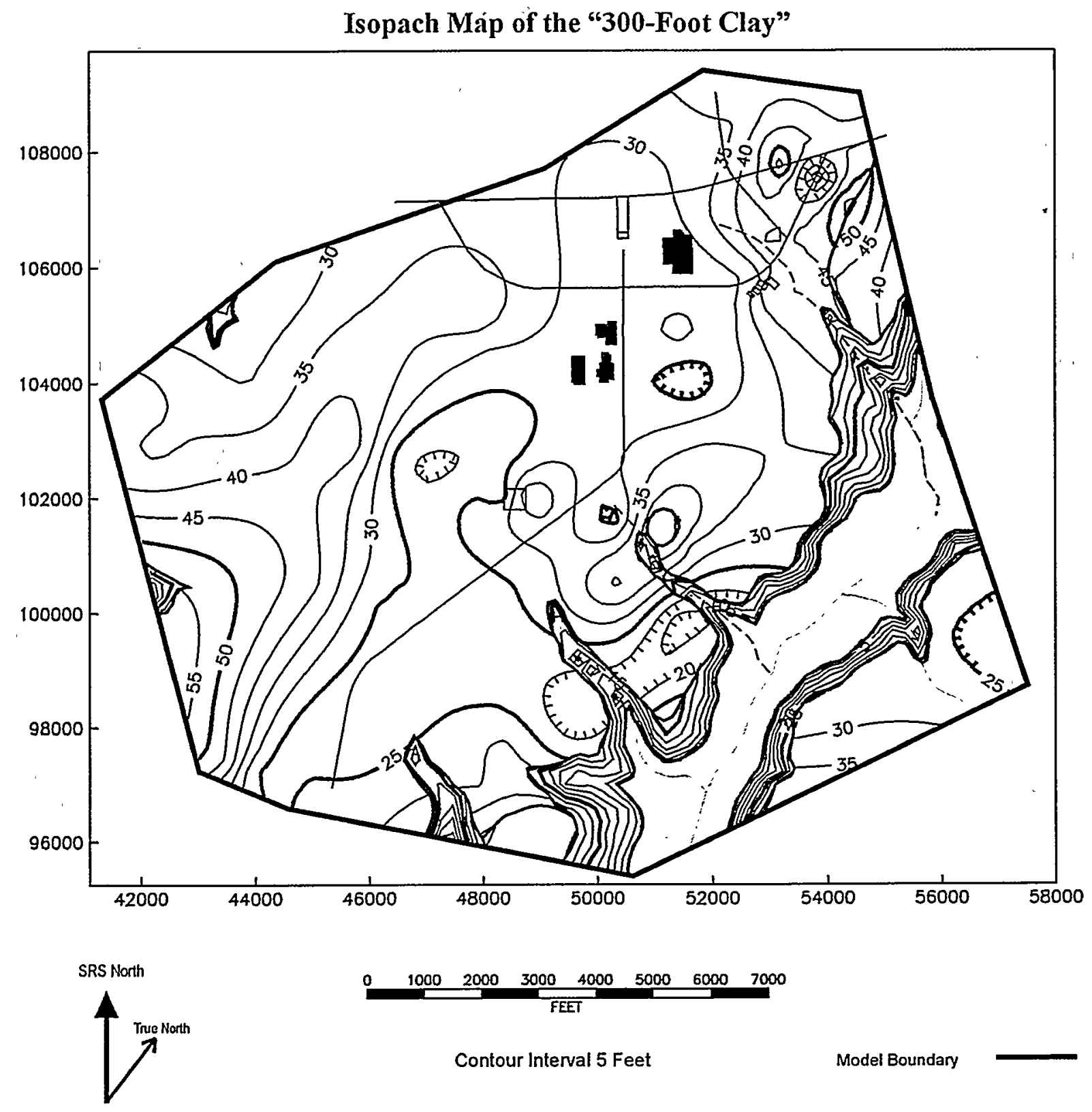

Figure 3-18. Isopach Map of the "300-Foot Clay" 
Geometric Mean of Mud within the "300-Foot Clay"
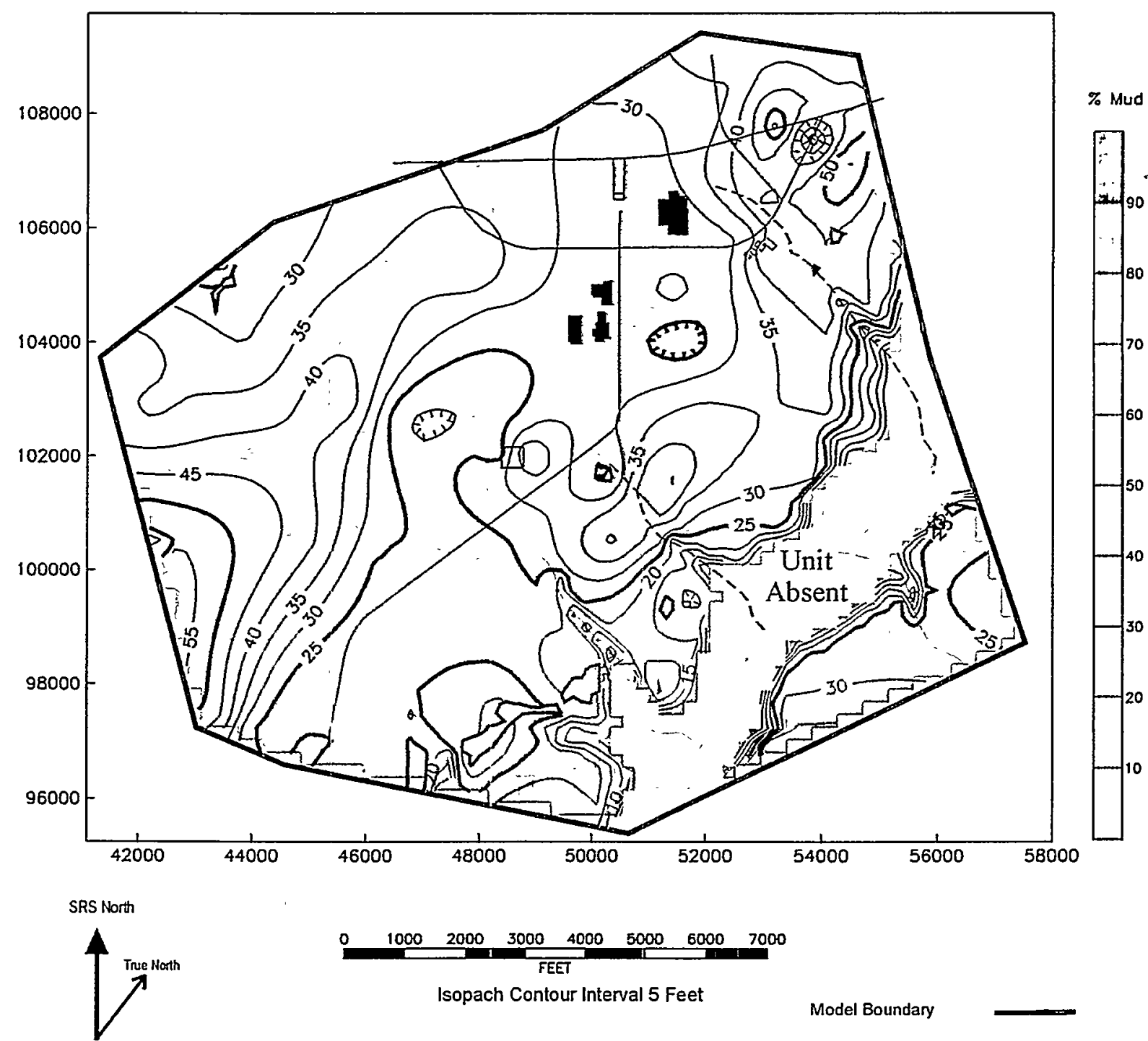

Isopach Contour Interval 5 Feet

Model Boundary

Figure 3-19. Geometric Mean of Mud Percentage within the "300-Foot Clay" 
Standard Deviation of Mud within the "300-Foot Clay"
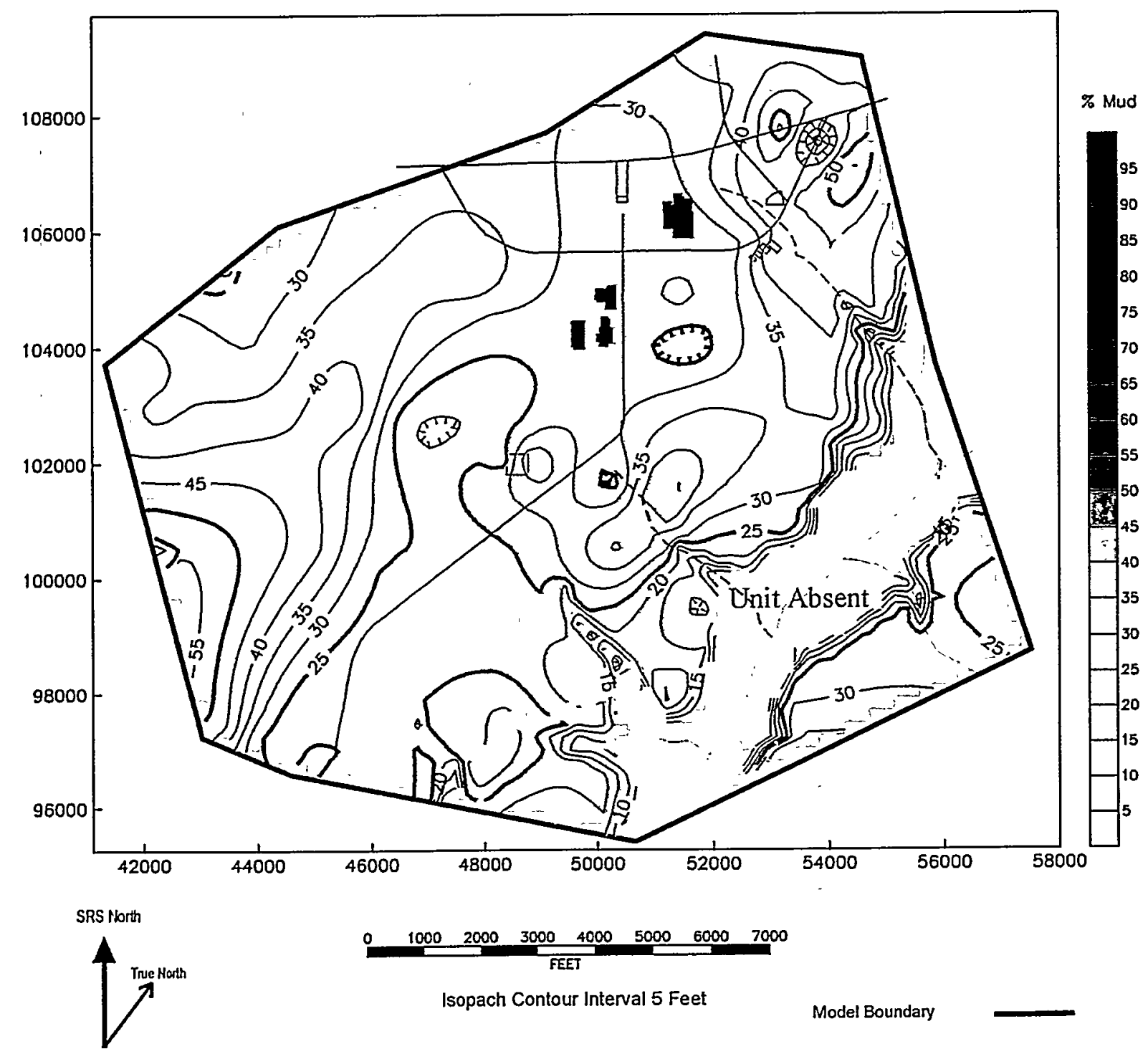

Isopach Contour Interval 5 Feet

Model Boundary

Figure 3-20. Standard Deviation of Mud Percentage within the "300-Foot Clay" 
Top of the "325-Foot Clay"
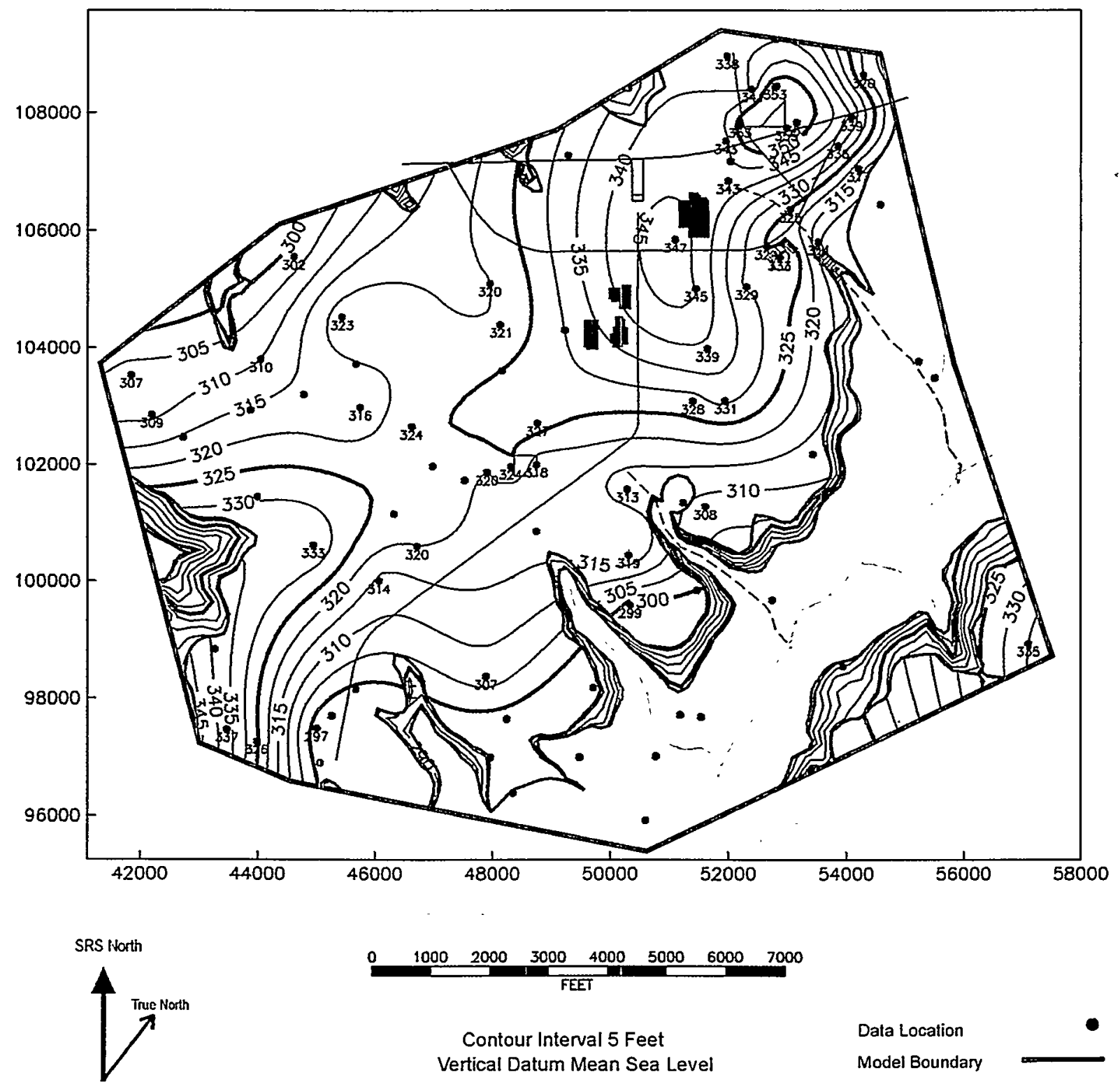

Contour Interval 5 Feet

Vertical Datum Mean Sea Level

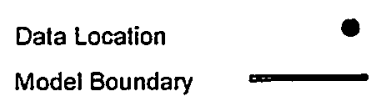

Figure 3-21. Altitude Contour Map of the Top of the "325-Foot Clay"/Base of the Undifferentiated Sediments 

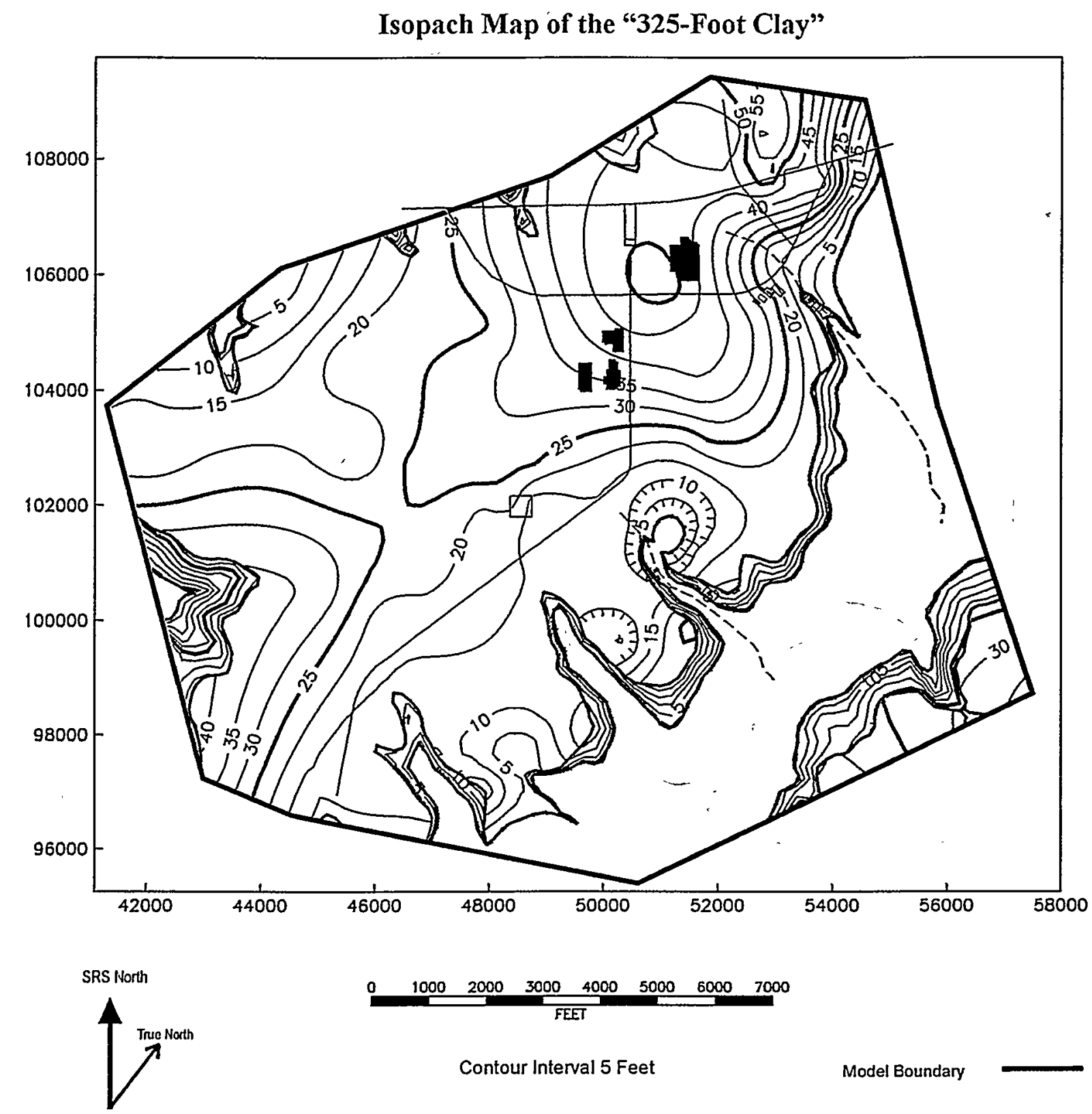

Contour Interval 5 Feet

Model Boundary

Figure 3-22. Isopach Map of the "325-Foot Clay" 


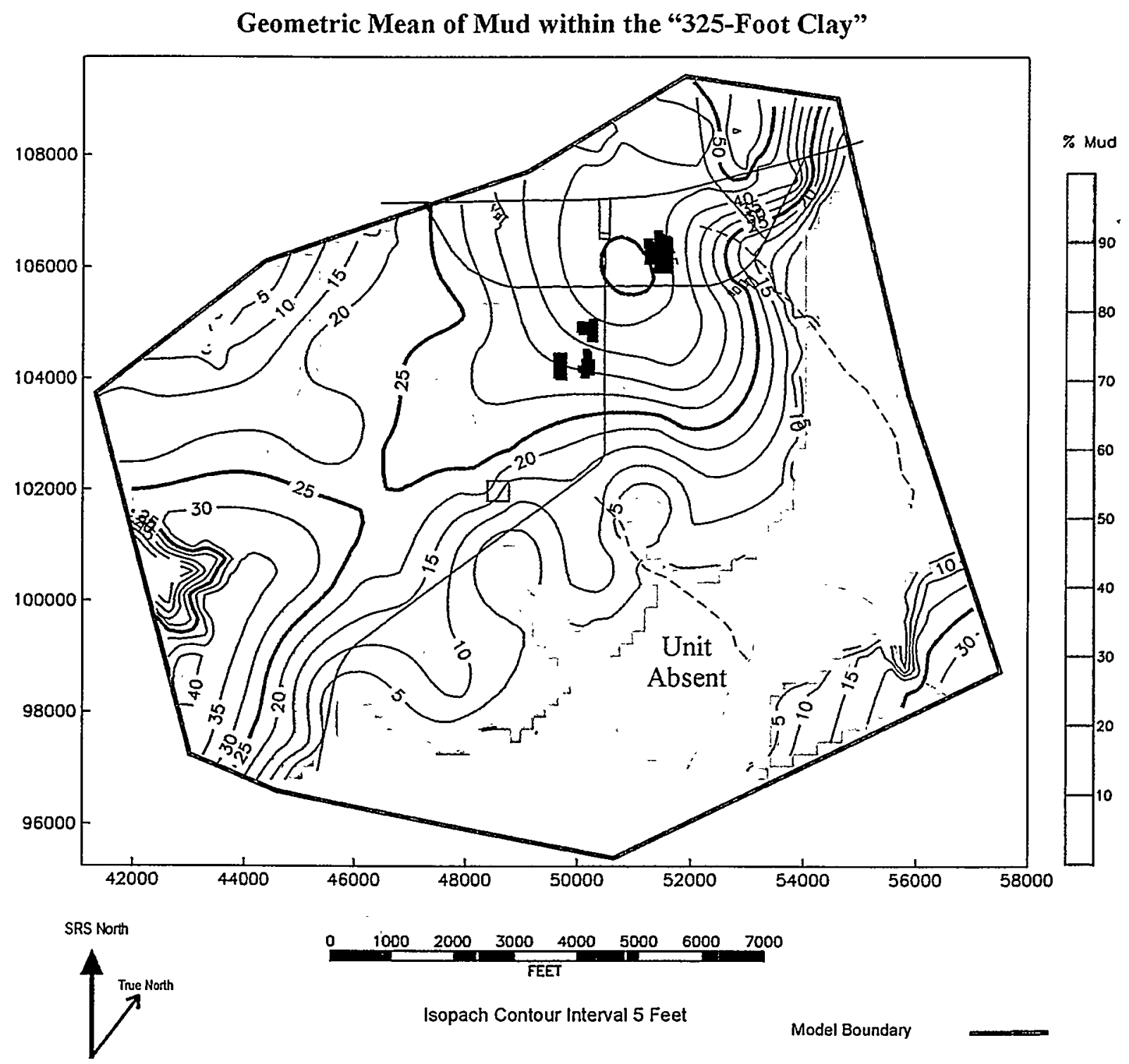

Figure 3-23. Geometric Mean of Mud Percentage within the "325-Foot Clay" 


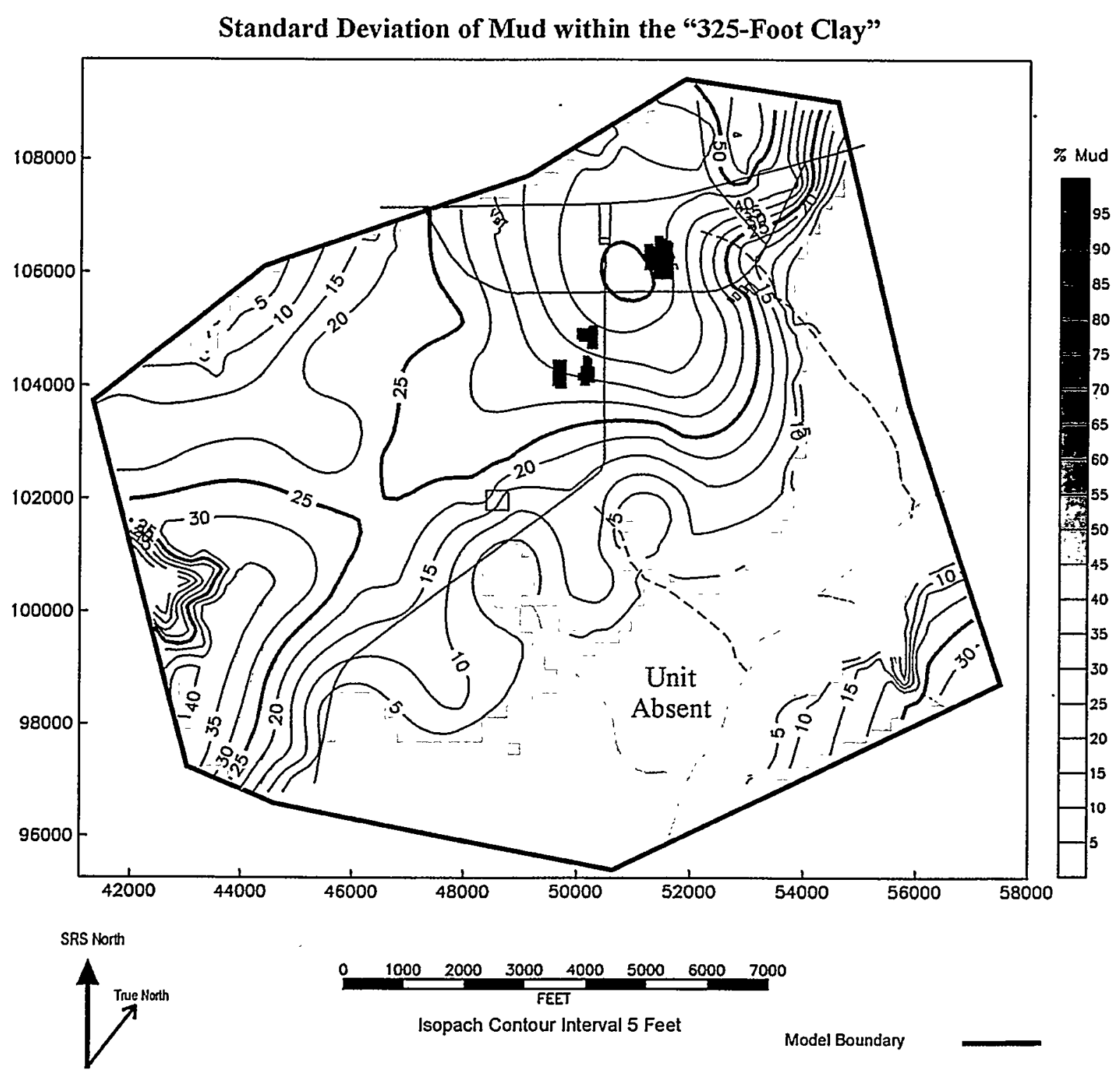

Figure 3-24. Standard Deviation of Mud Percentage within the "325-Foot Clay" 
This page intentionally left blank 


\subsection{SUMMARY AND RECOMMENDATIONS}

The extent of mud within hydrostratigraphic units can be modeled most effectively by selecting discrete depositional intervals within which to model lithologic parameters.

1. The "230-foot clay", "270-foot clay", "300-foot clay", and "325-foot clay" are delineated as depositional intervals within the MAAZ and the vadose zone beneath A/M Area. These intervals can be readily identified from detailed core descriptions and geophysical data and are mappable across the area.

2. All of these depositional intervals consist primarily of relatively permeable sand with sporadically distributed and discontinuous layers of mud-sized sediment (silt and clay).

3. Maps of mud distribution indicate that each of the intervals contain locally significant clay layers that are sporadically distributed and laterally discontinuous, however the individual clay layers cannot be mapped at the scale used in this study.

4. The discontinuous nature of the clay layers and the primarily sandy lithology of the sediment within the vadose zone suggest that certain areas may serve as preferential pathways for DNAPL migration.

5. The GCCZ is probably the most laterally consistent confining interval among the units within the Steed Pond aquifer and vadose zone.

Recommendations for future work:

Couple the results of this facies analysis with measurements of soil and groundwater contamination to refine the models for DNAPL extent and plume geometry beneath $A / M$ Area. For best results, this should be done in areas with very closely spaced data points. This will enhance the resolution of the resulting model and improve the ability to determine the vertical and horizontal extent of the discontinuous clay layers within the vadose zone.

Refine data from USGS digital elevation models (DEM) by validating the USGS data set with surveyed points within the study area. This will minimize the errors associated with poorer grid resolution in the stream valleys and the lack of finished-grade contours in the USGS data set. 
This page intentionally left blank 


\subsection{REFERENCES}

Aadland, R. K., Harris, M. K. , Lewis, C. M., Gaughan, T. F., and Westbrook, T. M., 1991. Hydrostratigraphy of the General Separations Area, Savannah River Site (SRS), South Carolina, WSRC-RP-91-13, Westinghouse Savannah River Company, Aiken, SC 29808.

Aadland, R. K., Gellici, J. A, and Thayer, P. A., 1995a. Hydrogeologic Framework of WestCentral South Carolina, Report 5, Water Resources Division, South Carolina Department of Natural Resources, Columbia, SC.

Aadland, R. K., Lewis, S. E., and McAdams, T. D. 1995b. Hydrogeological Characterization Report for the A/M Area $(U)$. WSRC-RP-95-0052, Westinghouse Savannah River Company, Aiken, SC 29808.

Christensen, E. J. and Gordon, D. E., 1983. Technical Summary of Groundwater Quality Protection Program at Savannah River Plant, Volume I-Site Geohydrology, and Solid and Hazardous Wastes, DPST-83-0829, E. I. du Pont de Nemours \& Co., Savannah River Laboratory, Aiken, SC 29808.

Colquhoun, D. J., Woollen, I. D., Van Nieuwenhuise, D. S., Padgett, G. G., Oldham, R. W., Boylan, D. C., Bishop, J. W., and Howell, P. D., 1983. Surface and Subsurface Stratigraphy, Structure and Aquifers of the South Carolina Coastal Plain, South Carolina Department of Health and Environmental Control Report, ISBN 0-9613154-0-7, Columbia, SC.

Eddy, C. A., Looney, B. B., Dougherty, J. M., Hazen, T. C., and Kaback, D. S., 1991. Characterization of the Geology, Geochemistry, Hydrology, and Microbiology of the In Situ Air Stripping Demonstration Site at the Savannah River Site, WSRC-RD-91-21, Westinghouse Savannah River Company, Aiken, SC 29808.

Fallaw, W. C., and Sargent, K. A., 1982. Subsurface Geology of the A/M Areas at the Savannah River Plant. SRT-EST-97-187, Final Report for Subcontract AX 715063, E. I. du Pont de Nemours \& Co., Savannah River laboratory, Aiken, SC 29808.

Fallaw, W. C. and Price, V., 1992. "Outline of Stratigraphy at the Savannah River Site", Geological Investigations of the Central Savannah River Area, South Carolina and Georgia, Fallaw, W. C., and Price, V., eds., Carolina Geological Society Field Trip Guide Book, November 13-15, 1992, CGS-92-B-11-1-33, U.S. Department of Energy and S.C. Geological Survey. 
Fallaw, W. C. and Price, V., 1995. "Stratigraphy of the Savannah River Site and Vicinity", Southeastern Geology, 35: 21-58.

Fallaw, W. C., Price, V., and Thayer, P., 1990. "Stratigraphy of the Savannah River Site, South Carolina", Savannah River Region: Transition Between the Gulf and Atlantic Coastal Plains, Proceedings of the Second Bald Head Island Conference on Coastal Plains Geology, University of North Carolina at Wilmington, pp 29-32.

Gordon, D. E., 1982. Preliminary Technical Summary M-Area Groundwater Cleanup Facility, DPST-82-0069, E. I. du Pont de Nemours \& Co., Savannah River Laboratory, Aiken, SC 29808.

HydroGeoLogic, 1996, Development of a Fully Three-Dimensional Groundwater Flow Model for the A/M Area Using Data Fusion, Final Report Prepared under Subcontract AA82250N, HydroGeoLogic, Inc., Herndon, VA 20170.

Jackson, D. G., Jr., Payne, T. H., Looney, B. B., and Rossabi, J., 1996. Estimating the Extent and Thickness of DNAPL within the A/M Area of the Savannah River Site (U), WSRC-RP96-0574, Westinghouse Savannah River Company, Aiken, SC 29808.

Jackson, D. G., Jr., Looney, B. B., and Campbell, H. W., 1997. Assessment of Chlorinated Solvent Contamination in the Crouch Branch Aquifer of the A/M Area $(U)$, WSRC-RP-9700247, Westinghouse Savannah River Company, Aiken, SC 29808.

Jackson, D. G, 1994. Three-Dimensional Groundwater Flow Model for A/M Area, SRT-ESS94-774, Westinghouse Savannah River Company, Aiken, SC 29808.

Lewis, S. E. and Aadland, R. K., 1992. Hydrogeologic Setting of A/M Area: Framework for Groundwater Transport (U), WSRC-RP-92-0355, Westinghouse Savannah River Company, Aiken, SC 29808.

Lewis, S. E. and Aadland, R. K., 1994. Hydrogeologic Setting of A/M Area: Framework for Groundwater Transport (U), WSRC-RP-92-0355, Westinghouse Savannah River Company, Aiken, SC 29808.

Logan, W. R. and Euler, G. M., 1989. Geology and Groundwater Resources of Allendale, Bamberg, and Barnwell Counties and Part of Aiken County, South Carolina, South Carolina Water Resources Commission Report 155, Columbia, SC. 
Looney, B. B., Rossabi, J. R., and Tuck, D. M., 1992. Assessing DNAPL contamination, A/M-Area, Savannah River Site: Phase I Results (U), WSRC-RP-92-1302, Westinghouse Savannah River Company, Aiken, SC 29808.

Marine, I. W. and Bledsoe, H. W. 1984. Supplemental Technical Summary M-Area Groundwater Investigation, DPSTD-84-0112, E. I. du Pont de Nemours \& Co., Savannah River Laboratory, Aiken, SC 29808.

Schlumberger, 1996a. Geophysical Log for GCB-1, Run No. 1, September 4, 1996, SRS Local Grid Coordinates Converted from UTM Provided in Log Header, Schlumberger Wireline Services Inc., Houston, TX.

Schlumberger, 1996b. Phasor - Induction - Gamma Ray Geophysical Log for SRS Well GCB-2, Run No. 1, July 2, 1996 SRS Local Grid Coordinates Converted from UTM Provided in Log Header, Schlumberger Wireline Services Inc., Houston, TX.

Siple, G. E., 1967. Geology and Ground Water of the Savannah River Plant and Vicinity, South Carolina, U.S. Geological Survey Water Supply Paper 1841.

Western-Atlas, 1996. Geophysical Log for GCB-3: Digital Spectralog, Dual Induction Focused Log, Magnetic Resonance Log and Compensated 2-Densilog, Run No. 1, July 26, 1996, Western-Atlas Wireline, Inc.

WSRC, 1990. "ESSOP-2-15: Microscopic Examination of Sediment Cores", Environmental Sciences Section Operating Procedures, Manual WSRC-L-14.1, Westinghouse Savannah River Company, Aiken, SC 29808.

WSRC, 1996a. Environmental Protection Department's Well Inventory (U), ESH-EMS-960488, Westinghouse Savannah River Company, Aiken, SC 29808.

WSRC, 1996b. A/M Area Western Sector Characterization Phase II Report (U), WSRC-RP-96-00108, Westinghouse Savannah River Company, Aiken, SC 29808.

WSRC, 1997. Upper Three Runs Watershed, A/M Area Advanced Geological Study, Part 3 of 3, Geological Interpretation of the Structure and Stratigraphy of the A/M Area, Savannah River Site, South Carolina (U), WSRC-RP-97-0186, Westinghouse Savannah River Company, Aiken, SC 29808. 
WSRC, 1998. Baseline Mapping Study of the Steed Pond Aquifer and Crouch Branch Confining Unit Beneath A/M Area, Savannah River Site, Aiken, South Carolina (U), WSRCTR-98-00357, Westinghouse Savannah River Company, Aiken, SC 29808 
WSRC-TR-99-00295

A-1

APPENDIX A. Core Descriptions

APPENDIXA CORE DATA.txt 
This page intentionally left blank 


\section{APPENDIX B. $\quad$ SRS Core Logging Format}

\section{NOTE:}

This appendix presents an explanation of all data fields in the description code used at SRS. Database fieldnames are indicated with underlined, boldface type. Superheadings (groups of related fields) are indicated in italics with underlined, boldface type. Content is adapted from WSRC ESSOP-2-15, Binocular Examination of Sediment Core Samples.

\section{GENERAL}

1). Make letters and numbers clear and unambiguous. Use standard, block and uppercase letters. Use letters and numbers only; no symbols.

2). Left justify letters; Right Justify numbers.

3). Estimating percentages

-If constituent $<10 \%$ or $>90 \%$, use increments of $1 \%$

-If constituent between $10 \%$ and $90 \%$, use increments of $5 \%$

-Highest value is $99 \%$

-Use .1 for trace quantities $(<1 \%)$

4). Core Description

Log core from bottom up. Slice core to observe sedimentary structures. Thin layers or laminae, less than a few inches, should be noted under STRUCTURE.

Certain properties are best determined in hand specimen: color, structure, maximum size, roundness, sorting, etc., are best determined with a binocular microscope.

5). If there is sediment, especially pebbles and sand, in the top few inches of a core that is obviously different from the underlying material, it probably fell down ("caved") from up the hole and should not be described. 


\section{APPENDIX B. $\quad$ SRS Core Logging Format (Continued)}

6). Put your initials (e.g., LOGGED BY: PAT) and date (DD-MM-YY format) in upper left corner of the log sheet. Fill in the page numbers in upper right corner (e.g., 1 of 8). Check in lower right corner of log sheet whether core is WET or DRY. Log core in sequence and record all page numbers in sequence.

WELL (Cols. 1-8)

Record only on top line of sheet.

Cols 1-3 [Well Series] Letter or letters. Left justify (LJ).

Cols. 4-6 [Well Number] Number. Right justify (RJ).

Cols. 7-8 [Screen Zone] Letter. Left Justify (LJ).

Examples: P_18TA

CMP_09_

\section{DEPTH (Cols. 9-12)}

Starting at bottom of core, describe in one-foot increments. Assume that missing core results from failure to sample bottom of interval. Record on computer load sheets from the bottom of the sheet upward.

(Right Justify) (RJ).

Examples: 115 


\section{APPENDIX B. $\quad$ SRS Core Logging Format (Continued)}

RECOVERY [INDUR] $($ Col. 14) $=$ Degree of lithification

$1=$ Loose $\quad$. Core unlithified

$2=$ Friable $\quad$ Core coherent, but easily disaggregated.

$3=$ Hard $\quad$ Core firm, but grains can be dislodged

4 = Very Hard Hard rock (some carbonates, silicified rock, or iron oxides).

COLOR (Cols. 15-19)

Left Justify (LJ).

Use most common or overall color. Prefix main rock color with shade. (i.e., light, medium, or dark).

Colors: Use first two letters of color:

$\mathrm{BR}=\mathrm{Brown}$

$\mathrm{OR}=$ Orange .

PI $\quad=$ Pink

PU = Purple

$\mathrm{RE}=\mathrm{Red}$

$\mathrm{TA}=\mathrm{Tan}$

$\mathrm{WH}=$ White

$\mathrm{YE}=$ Yellow

Exceptions:

$\mathrm{BE}=\mathrm{Blue}$ 
APPENDIX B. $\quad$ SRS Core Logging Format (Continued)

$$
\begin{aligned}
\mathrm{BK} & =\text { Black } \\
\mathrm{GN} & =\text { Green } \\
\mathrm{GY} & =\text { Gray } \\
\mathrm{MT} & =\text { Mottled } \\
\mathrm{VAR} & =\text { Variegated }
\end{aligned}
$$

\section{STRUCTURE $($ Cols. 20-27) $=$ Sedimentary Structures}

\section{Left Justify.}

Leave BLANK for massive, structureless beds.

$\mathrm{B}=$ Color banded $(\mathrm{B}+$ color; e.g., $\mathrm{BGY}=$ banded gray $)$

$$
\begin{aligned}
& \mathrm{BR}=\text { Brecciated } \\
& \mathrm{BU}=\text { Burrow } \\
& \mathrm{CLB}=\text { Clay Balls (Any gravel sized clay) } \\
& \mathrm{CTN}=\text { Chert Nodule } \\
& \mathrm{FE}=\text { Iron oxide nodule } \\
& \mathrm{FR}=\text { Fracture } \\
& \mathrm{FS}=\text { Fissile } \\
& \mathrm{ICA}=\text { Interbedded or interlaminated Calcarenite } \\
& \text { ICL = Interbedded or interlaminated Clay (silt }+ \text { clay) } \\
& \text { IMC = Interbedded or interlaminated Micrite } \\
& \text { IPB = Interbedded or interlaminated Pebbles }
\end{aligned}
$$


APPENDIX B. SRS Core Logging Format (Continued)

$$
\begin{aligned}
& \text { ISD = Interbedded or interlaminated Sand } \\
& \text { MCB = Micrite Balls or fragments (gravel sized) } \\
& \text { MT }=\text { Mottled } \\
& \text { PE }=\text { Pelleted } \\
& \text { PY }=\text { Pyrite } \\
& \text { RT }=\text { Root structure (cast or mold) } \\
& \text { VN }=\text { Mineral vein } \\
& \text { WSP = Wispy laminations or bedding } \\
& \text { XB }=\text { Cross-bedded }
\end{aligned}
$$

Examples: IPBCLB $=$ Interbedded pebbles and clay balls

$$
\text { PYVN = Pyrite Vein }
$$

SILICATE [ Use only for siliciclastic fraction] (Cols. 28-38)

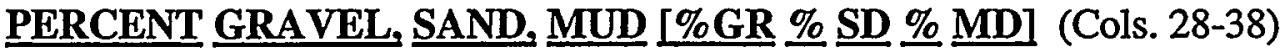

Normalize estimated percent siliciclastic gravel, sand and mud (silt + clay) to $100 \%$, and record in appropriate column.

Right Justify.

$$
\begin{aligned}
& \text { \%GR (Cols. 28-29) = \% GRAVEL (>2mm) } \\
& \text { \%SD (Cols. 30-31) }=\% \text { SAND }(2 \mathrm{~mm}-0.0625 \mathrm{~mm}) \\
& \% \mathrm{MD}(\text { Cols. 32-33) }=\% \operatorname{MUD}(<0.0625 \mathrm{~mm})
\end{aligned}
$$

SIZE (Cols. 34-37) 


\section{APPENDIX B. SRS Core Logging Format (Continued)}

\section{MX (Cols. 34-35 = MAXIMUM SIZE}

Left Justify.

Record maximum size of siliciclastic fraction using following abbreviations:

$$
\begin{aligned}
& \mathrm{BO}=\text { Boulder }(>256 \mathrm{~mm}) \\
& \mathrm{UC}=\text { Upper Cobble }(128-256 \mathrm{~mm}) \\
& \mathrm{LC}=\text { Lower Cobble }(64-128 \mathrm{~mm}) \\
& \mathrm{UP}=\text { Upper Cobble }(16-64 \mathrm{~mm}) \\
& \mathrm{LP}=\text { Lower Pebble }(4-16 \mathrm{~mm}) \\
& \mathrm{GR}=\text { Granule }(2-4 \mathrm{~mm}) \\
& \mathrm{VC}=\text { Very Coarse sand }(1-2 \mathrm{~mm}) \\
& \mathrm{C}=\text { Coarse sand }(0.5-1 \mathrm{~mm}) \\
& \mathrm{M}=\text { Medium sand }(0.25-0.5 \mathrm{~mm}) \\
& F \quad=\text { Fine sand }(0.125-0.25) \\
& \mathrm{VF}=\text { Very Fine sand }(0.0625-0.125 \mathrm{~mm}) \\
& C L=\text { Silt and Clay }(<0.0625 \mathrm{~mm})
\end{aligned}
$$

MD $($ Cols. 36-37) $=$ MODAL SIZE

\section{Modal Size $=$ Most Abundant Size Fraction}

Left Justify.

May not be applicable to some carbonates (i.e., those that contain little or no siliciclastic material). 
APPENDIX B. SRS Core Logging Format (Continued)

Record modal size using following abbreviations:

$$
\begin{aligned}
& \mathrm{BO}=\text { Boulder }(>256 \mathrm{~mm}) \\
& \mathrm{UC}=\text { Upper Cobble }(128-256 \mathrm{~mm}) \\
& \mathrm{LC}=\text { Lower Cobble }(64-128 \mathrm{~mm}) \\
& \mathrm{UP}=\text { Upper Cobble }(16-64 \mathrm{~mm}) \\
& \mathrm{LP}=\text { Lower Pebble }(4-16 \mathrm{~mm}) \\
& \mathrm{GR}=\text { Granule }(2-4 \mathrm{~mm}) \\
& \mathrm{VC}=\text { Very Coarse sand }(1-2 \mathrm{~mm}) \\
& \mathrm{C}=\text { Coarse sand }(0.5-1 \mathrm{~mm}) \\
& M \quad=\text { Medium sand }(0.25-0.5 \mathrm{~mm}) \\
& F \quad=\text { Fine sand }(0.125-0.25) \\
& \text { VF }=\text { Very Fine sand }(0.0625-0.125 \mathrm{~mm}) \\
& C L=\text { Silt and Clay }(<0.0625 \mathrm{~mm})
\end{aligned}
$$

\section{ROUNDNESS [RND] (Col. 38)}

Record Average Roundness of Quartz grains only, using following scale:

$$
\begin{aligned}
& 1=\text { Very angular } \\
& 2=\text { Angular } \\
& 3=\text { Subangular } \\
& 4=\text { Subrounded } \\
& 6=\text { Rounded }
\end{aligned}
$$


APPENDIX B. $\quad$ SRS Core Logging Format (Continued)

$$
9=\text { Well-rounded }
$$

CARBONATE LITHOLOGY [Use only for carbonate fraction] (Cols. 39-48)

PERCENT (CARBONATE) GRAVEL, SAND, MUD [\%GR, \%SD, \%MD] (Cols. 39-44)

Normalize estimated percent carbonate gravel, sand, and mud to $100 \%$, and record in appropriate column.

Right Justify.

$$
\begin{aligned}
& \text { \%GR (Cols. 39-40) }=\% \text { CARBONATE GRAVEL }(>\mathbf{2 m m}) \\
& \text { \%SD (Cols. 41-42) }=\% \text { CARBONATE SAND }(>\mathbf{2 m m - 0 . 0 6 2 5 m m}) \\
& \text { \%MD (Cols. 43-44) }=\% \text { CARBONATE MUD }(>\mathbf{0 . 0 6 2 5 m m})
\end{aligned}
$$

\section{PERCENT CEMENT [\%CMT] (Cols. 45-46)}

Record total percent carbonate plus other cement (silica, iron sulfides, iron oxides, phosphate, glauconite, etc.).

Right Justify.

\section{PERCENT CARBONATE [\% CAR] (Cols. 47-48)}

Check any suspicious sample with $10 \%$ hydrochloric acid, and estimate total percent carbonate.

Record total percent carbonate (Sum of matrix, cement, fossils, and other carbonate grains), without normalizing to $100 \%$.

Right Justify.

ROCK NAME [\% NAME] (Cols. 49-56) 


\section{APPENDIX B. $\quad$ SRS Core Logging Format (Continued)}

Left Justify.

\section{No Carbonate Present $(<1 \%$ Carbonate)}

A. If one size fraction $75 \%$ or greater, use following:

$\mathrm{PB}=$ Pebbles

$\mathrm{SD}=$ Sand

ST $=$ Silt

$\mathrm{CL}=$ Clay

B. If another fraction is $25 \%$ or greater, use as a modifier with most abundant fraction last.

Example: $\mathrm{SDCL}=$ Sandy Clay

C. If two or more components are $25 \%$ or greater, list the most abundant fraction last.

Example: PBSDCL =Pebbly, Sandy Clay

Note: In most clastic sediments, it is difficult to distinguish silt from clay. Generally, use CL (clay) for mixtures of clay and silt. Use ST (silt) only for silt or siltstone that is highly porous. 
APPENDIX B. $\quad$ SRS Core Logging Format (Continued)

\title{
II. Carbonate Present ( $<1 \%$ Carbonate)
}

\author{
A. If Carbonate $75 \%$ or greater: \\ $\mathrm{BL}=$ Biomoldic Limestone (numerous megafossil molds) \\ $\mathrm{CA}=$ Calcarenite (granular, sand-sized carbonate) \\ $\mathrm{GM}=$ Green Micrite (looks like green clay) \\ $\mathrm{MC}=$ Micrite (lime mud; chalk) \\ SL $=$ Shell Limestone (shells \&/or shell fragments) \\ $\mathrm{VL}=$ Vuggy Limestone (numerous vugs) \\ $\mathrm{XL}=$ Crystalline Limestone (hard, massive)
}

\section{B. If Carbonate 50-75\%:}

Prefix carbonate rock name with other constituent(s), least abundant first.

Examples: SDSL $\quad=$ Sandy Shell Limestone

GLSDMC = Glauconitic Sandy Micrite

\section{If Carbonate 1-50\%:}

Prefix main rock name with carbonate modifier.

Examples: $\mathrm{CM}=$ Carbonated-cemented

$\mathrm{CMSD}=$ Carbonate-cemented siliciclastic Sand

MCCL = Micritic Clay (clay is silicate)

SLSD = Shelly siliciclastic Sand 


\section{APPENDIX B. SRS Core Logging Format (Continued)}

\section{Other Lithologic Types}

Must be $25 \%$ or greater in siliciclastic to be used as a modifier.

Use the following abbreviations:
$\mathrm{AR}=$ Arkosic (feldspathic)
$\mathrm{CT}=$ Chert cement or replacement (use for any silica)
$\mathrm{FE}=$ Iron oxides (cement or replacement)
$\mathrm{GL}$ = Glauconite (green grains or cement)
LG = Lignite (soft, brown to black, woody fragments)
MU = Muscovite
$\mathrm{PH}=$ Phosphate (brown to black shell, bone, or tooth)
PY = Iron sulfides (pyrite or marcasite)

Examples:

$$
\begin{array}{ll}
\text { PHMC } & =\text { Phosphatic Micrite } \\
\text { CTSLMC } & =\text { Shelly Micrite with Chert }
\end{array}
$$

\section{SORTING [SORT] (Col. 57)}

Record overall sorting of rock using following scale:

$$
\begin{array}{ll}
\text { W (Well sorted) } & \text { If } 90 \% \text { within } 2 \text { size classes } \\
\text { M (Moderately sorted) } & \text { If } 90 \% \text { within } 4 \text { size classes } \\
\text { P (Poorly sorted) } & \text { If } 90 \%>4 \text { size classes } \\
\text { V (Very poorly sorted) } & \text { If } 90 \%>6 \text { size classes }
\end{array}
$$




\section{APPENDIX B. SRS Core Logging Format (Continued)}

If a sand contains $>25 \% \mathrm{CL}$ (silt + clay) or $\mathrm{MC}$, use $\mathrm{P}$ or $\mathrm{V}$.

\section{PERCENT POROSITY [\%POR] (COL. 58-59)}

Use for all lithologies. Left Justify (LJ).

Estimate percent of large pores by looking at whole core; estimate percent of small pores ( $2 \mathrm{~mm})$ using binocular microscope. Total porosity is sum of large and small pores.

Use following scale:

$$
\begin{array}{ll}
\mathrm{P}(\text { Poor }) & =<5 \% \text { porosity } \\
\mathrm{M} \text { (Moderate) } & =5-15 \% \text { porosity } \\
\mathrm{G}(\mathrm{Good}) & =15-30 \% \text { porosity } \\
\mathrm{E}(\text { Excellent }) & =>30 \% \text { porosity }
\end{array}
$$

PORE TYPE [PORE TYPE] (Cols. 60-61)

Use for all lithologies.

Record most abundant pore type in Cols. 60-61 using the following abbreviations:

$$
\begin{aligned}
& \mathrm{BP}=\text { Between Particle (interparticle) pore } \\
& \mathrm{CH}=\text { Channel pore } \\
& \mathrm{MI}=\text { Micropore } \\
& \mathrm{MO}=\text { Moldic pore } \\
& \mathrm{VU}=\text { Vug pore } \\
& \mathrm{WP}=\text { Within Particle (intraparticle) pore }
\end{aligned}
$$




\section{APPENDIX B. SRS Core Logging Format (Continued)}

PERCENT MUSCOVITE [\%MUSC] (Cols. 62-63)

Record estimated volume percent muscovite.

Right Justify.

\section{PERCENT GLAUCONITE [\%GLAU] (Cols. 64-65)}

Record estimated volume percent glauconite (As grains, matrix, or cement).

Right Justify.

PERCENT LIGNITE [ \%LIGN] (Cols. 66-67)

Record estimated volume percent lignite (As dark, soft, woody, peaty or coaly material).

Right Justify:

\section{PERCENT SULPHIDES [\%SULP] (Cols. 68-69)}

Record estimated volume percent marcasite or pyrite.

Right Justify.

\section{HEAVY MINERALS [HEAV] (Col. 70)}

Record estimated volume percent heavy minerals (opaque and non-opaque) using the following scale:

$$
\begin{array}{ll}
\mathrm{R}(\mathrm{Rare}) & =\text { Very few heavy mineral grains } \\
\mathrm{C}(\text { Common }) & =\text { Heavy mineral grains easy to find }
\end{array}
$$


APPENDIX B. SRS Core Logging Format (Continued)

$\mathrm{A}$ (Abundant) = "Loaded" with heavy mineral grains

FOSSILS (Cols. 71-80)

List most abundant first. Do not skip spaces between abbreviations.

If fossils are present, but you can't identify, note YE for YES.

If silicified, note CT first, then type(s).

Left justify.

Use the following abbreviations (for FOSSUS):

$$
\begin{aligned}
& \mathrm{BA}=\text { Barnacle } \\
& \mathrm{BR}=\text { Bryozoan } \\
& \mathrm{FO}=\text { Foraminifer } \\
& \mathrm{GA}=\text { Gastropod } \\
& \mathrm{GI}=\text { Crassostrea gigantissima } \\
& \mathrm{OS}=\text { Ostracode } \\
& \mathrm{PL}=\text { Pelecypod } \\
& \mathrm{SA}=\text { Echinoderm (sand dollar) } \\
& \mathrm{SP}=\text { Sponge spicule } \\
& \text { Examples: CTPLGA = Silicified Pelecypods and Gastropods }
\end{aligned}
$$

